\title{
Effectiveness of sleep extension on athletic performance and nutrition of female track athletes
}

Oluremi Famodu

West Virginia University

Follow this and additional works at: https://researchrepository.wvu.edu/etd

\section{Recommended Citation}

Famodu, Oluremi, "Effectiveness of sleep extension on athletic performance and nutrition of female track athletes" (2014). Graduate Theses, Dissertations, and Problem Reports. 306.

https://researchrepository.wvu.edu/etd/306

This Thesis is protected by copyright and/or related rights. It has been brought to you by the The Research Repository @ WVU with permission from the rights-holder(s). You are free to use this Thesis in any way that is permitted by the copyright and related rights legislation that applies to your use. For other uses you must obtain permission from the rights-holder(s) directly, unless additional rights are indicated by a Creative Commons license in the record and/ or on the work itself. This Thesis has been accepted for inclusion in WVU Graduate Theses, Dissertations, and Problem Reports collection by an authorized administrator of The Research Repository @ WVU. For more information, please contact researchrepository@mail.wvu.edu. 


\section{EFFECTIVENESS OF SLEEP EXTENSION ON \\ ATHLETIC PERFORMANCE AND NUTRITION OF FEMALE TRACK ATHLETES}

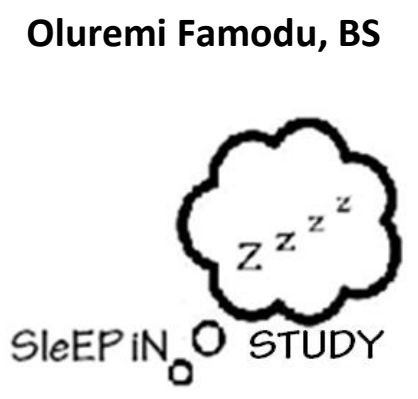

Thesis submitted

to the Davis College of Agriculture, Natural Resources \& Design

at West Virginia University

in partial fulfillment of the requirements for the degree of

Master of Science in

Nutrition \& Food Science

Thesis Committee:

Melissa Olfert, DrPH, MS, RDN, LD, Chair

Hawley Montgomery-Downs, PhD

Randall Bryner, PhD

Department of Animal \& Nutritional Sciences

Morgantown, West Virginia

2014

Keywords: Sleep Extension; Sleep Deprivation, Physical Performance, Nutrition, Athletes

Copyright 2014 Oluremi Famodu 


\section{ABSTRACT \\ Effects of extended sleep on female athlete's performance and nutrition}

\section{Oluremi Famodu}

Adequate sleep is an essential component to rest and recovery for athletes. Detrimental effects of inadequate sleep (sleep deprivation), on athletes' performance have been well documented. In contrast, increasing sleep (sleep extension), has not been thoroughly investigated in this population. Furthermore, the effect of sleep on an athlete's nutrition behaviors and choices has yet to be determined.

PURPOSE: The purpose of this study was to investigate the effects of one additional hour of sleep on performance and nutrition behaviors on collegiate, female, track and field athletes. METHODS: Twenty-one females (age $20.2 \pm 1.8$ yrs) maintained normal sleep habits for one week. Baseline data were collected and followed by a one week sleep extension period. Physical performance was measured using a standard anaerobic test (Wingate Anaerobic Test). The Automated Self Administered (ASA) 24-hour food-recall questionnaire was used to test nutrient intake. Reaction time and mood, used in association with sleep efficiency, were measured using the Psychomotor Vigilance Test (PVT) and Profile of Mood States (POMS), respectively. Significance was set at $p \leq 0.05$.

RESULTS: Subjects ( $n=21)$ significantly increased total sleep from baseline $(429.3 \pm 38$ minutes, $451.4 \pm 44.8$ minutes respectively; $p=0.03$ ). Subjects showed a trend towards improvements in peak power (692.9 \pm 213.2 watts versus $713.5 \pm 214.6$ watts) and slight decrements in fatigue index from baseline $(37.3 \pm 10.6 \%$ versus $38.8 \pm 8.42 \%)$, however these were not significant ( $p$ $=0.07, p=0.28$ respectively). Mean PVT scores remained unchanged $(p=0.98)$ and POMS scores significantly decreased $(p=0.01)$ following more sleep. Although not significant, the athletes showed increased caloric intake $(p=0.87)$ with increased percentage of total fat $(p=$ $0.24)$ after sleep extension.

CONCLUSION: No significant differences were seen in physical performance, however significant improvements in psychological performance (total mood disturbance score) was seen after sleep extension in college female track athletes. Increased caloric intake with an increase in dietary fat consumption was seen with more sleep, however not significant.

LIMITATIONS: Short sleep extension dosage may have limited the ability to detect a significant change in nutritional behaviors and physical performance in athletes. 


\section{ACKNOWLEDGEMENTS}

First and foremost, I would like to thank Dr. Melissa Olfert for providing me with the opportunity to work as a graduate student in her research lab for the creation of the SleEP iN Study (sleeping longer to enhance performance). I would also like to thank her for her time, encouragement and expertise throughout the past two years.

Next, I would like to thank my additional committee members Dr. Hawley MontgomeryDowns and Dr. Randall Bryner for their continued support and flexibility. I would also like to extend my appreciation to Dr. Christa Lilly for his statistical advice and expertise.

I would also like to thank my fellow interns, research team, family members and friends who have supported me throughout my year at West Virginia University. Your support and willingness to help has led me to my success throughout my journey through my Master's Program.

Lastly, my sincerest gratitude goes out to the West Virginia University female track athletes who volunteered in the participation of this study. The work completed here could not have been done without each of your efforts and contribution. 


\section{Table of Contents}

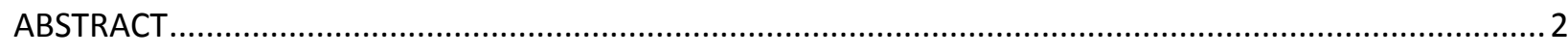

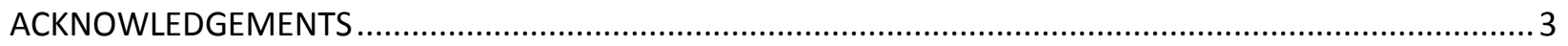

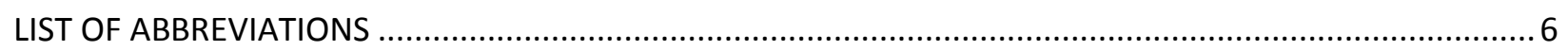

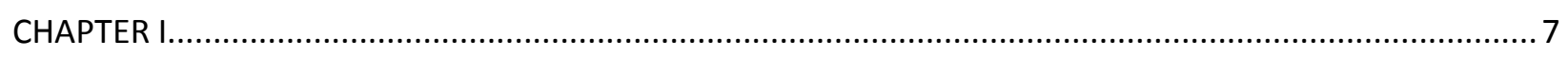

INTRODUCTION

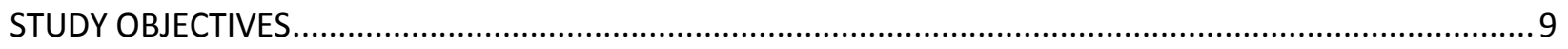

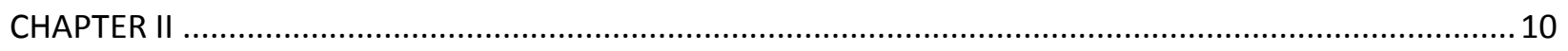

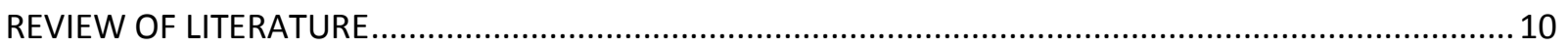

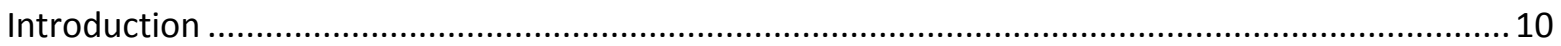

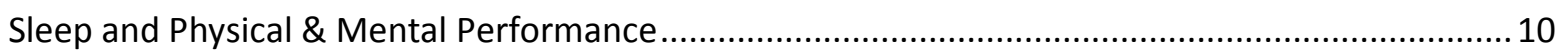

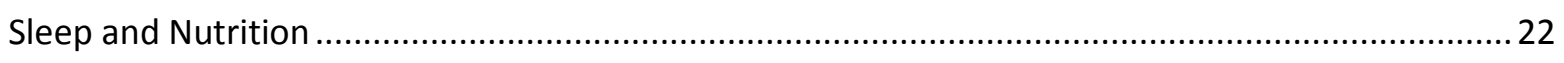

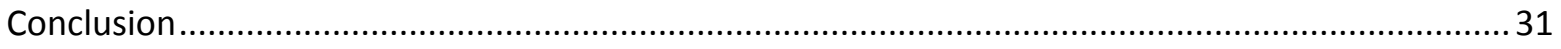

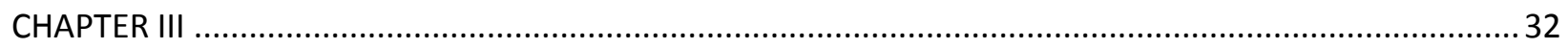

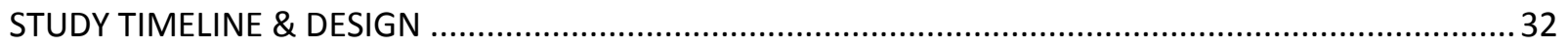

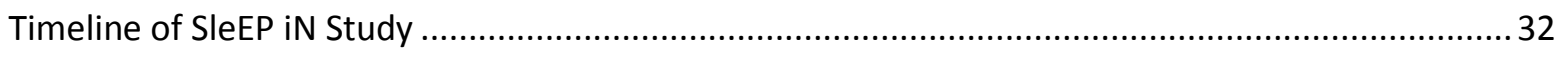

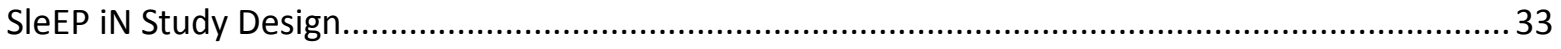

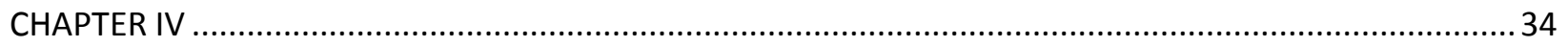

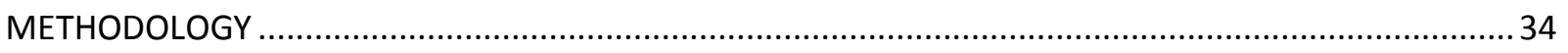

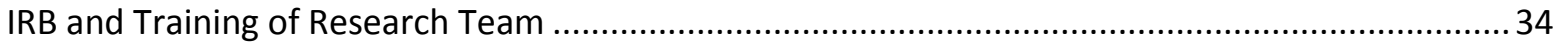

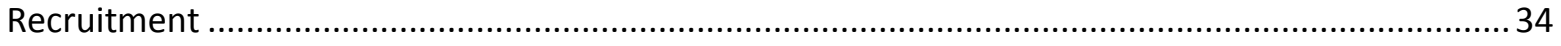

Informed Consent Process/Health History Questionnaire ............................................................ 35

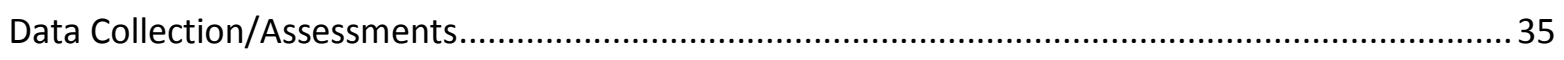

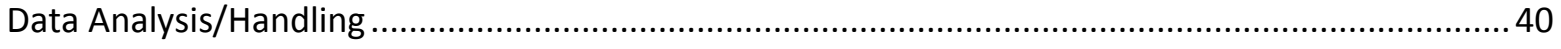

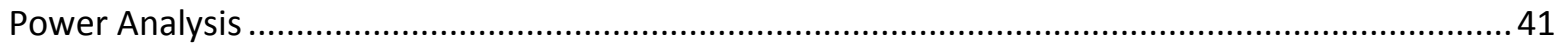

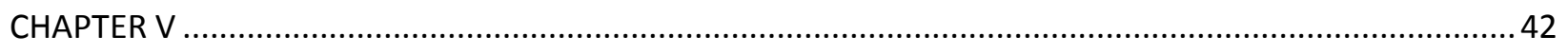

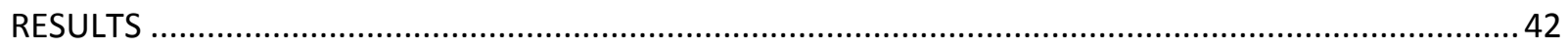

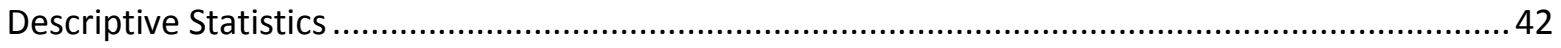

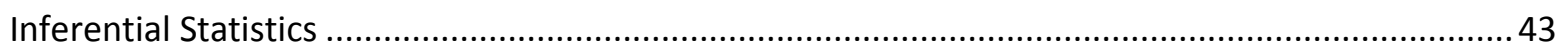

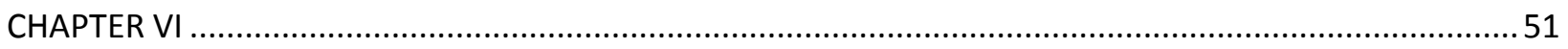




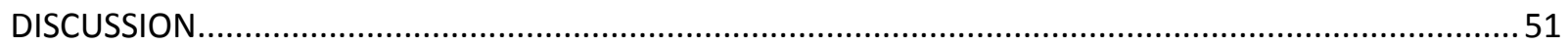

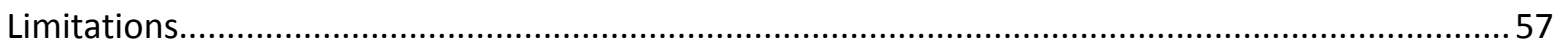

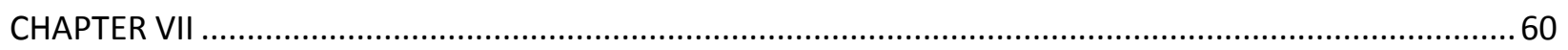

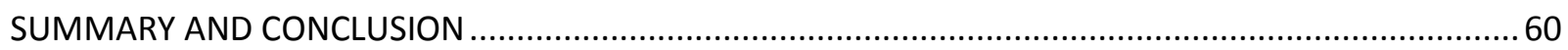

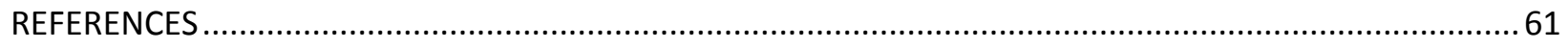

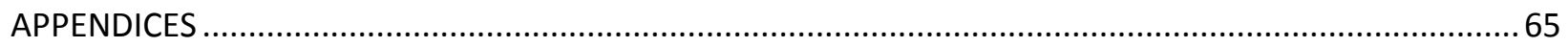

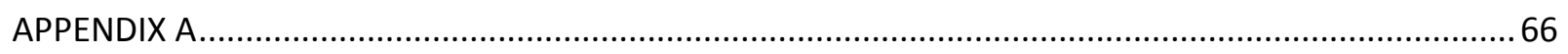

INSTITUTIONAL REVIEW BOARD APPROVAL AND CONSENT AND INFORMATION FORM .................66

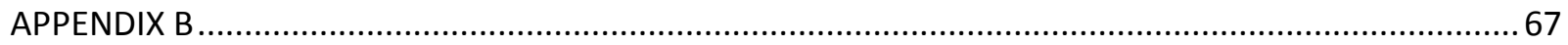

SIGNED LETTER OF APPROVAL BY WVU WOMEN'S TRACK AND FIELD COACH.............................67

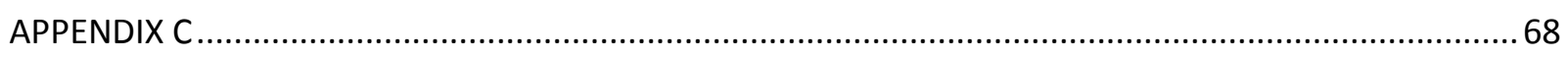

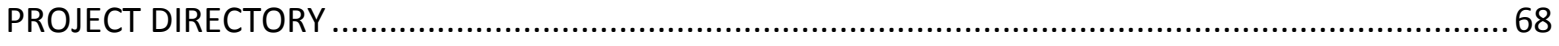

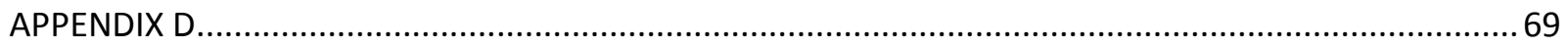

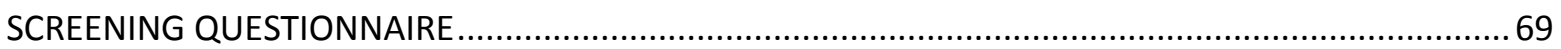

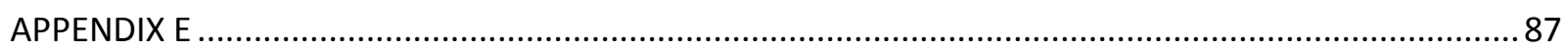

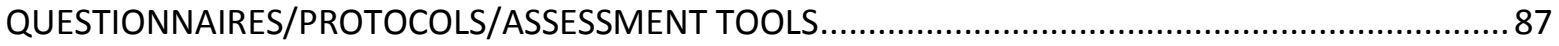

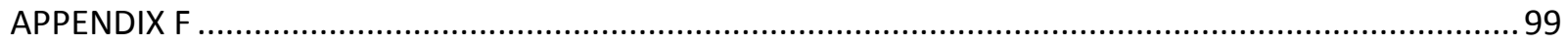

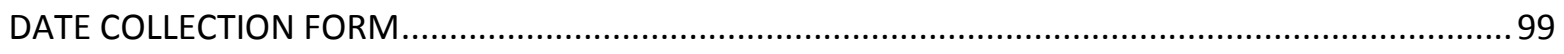

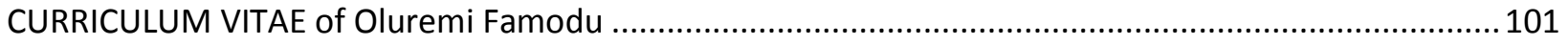




\section{LIST OF ABBREVIATIONS}

ASA-24-Automated Self Administered 24-Hour-Recall

$\mathrm{BMI}$ - Body Mass Index

CDC - Centers for Disease Control

CITI- Collaborative Institutional Training Initiative

GH- Growth Hormone

HPL-Human Performance Lab

IL-6-Interleukin 6

IRB- Institutional Review Board

MSLT- Multiple Sleep Latency Test

NCAA-National Collegiate Athletic Association

NHANES - National Health \& Nutrition Examination Survey

NREM- Non Rapid Eye Movement

OC-Oral Contraceptive

OR- Odds Ratio

POMS - Profile of Mood States

PSS-Perceived Stress Score

PVT - Psychomotor Vigilance Test

QOL-Quality of Life

REM- Rapid Eye Movement

SleEP iN - Sleeping Longer to Enhance Exercise Performance and Improve Nutrition

$\mathrm{VO}_{2}$ max- Maximal Oxygen Uptake

$\mathrm{VO}_{2}$-Resting Oxygen Uptake

WAnT-Wingate Anaerobic Test

WV - West Virginia

WVU - West Virginia University 


\section{CHAPTER I}

\section{INTRODUCTION}

Sleep is an essential component to rest and recovery, both physically and mentally ${ }^{(1)}$. Athletes may need more sleep than their non-sporting counterparts in order to recover from the amount of stress delivered from training and competing, but also to organize the information received from training ${ }^{(1)}$. Depriving oneself of sleep, it can lead to anxiety, depression, stress and other psychological problems ${ }^{(2,3)}$, which can impact an athlete's sport or expectation of sport. Also, sleep is needed in order to limit the loss of cognitive or motor abilities needed to excel in exercise performance ${ }^{(4)}$. Although it is argued whether athletes need more sleep than others, they potentially are getting less ${ }^{(5)}$. Therefore sleep and its potential performance enhancing effects continues to be investigated by researchers.

Nutrition is also said to enhance performance ${ }^{(6,7)}$. There is increasing research connecting sleep and nutrition; depriving oneself of sleep can lead to appetite stimulation and increased levels of hunger due to hormone imbalance ${ }^{(8)}$. These behaviors could be detrimental to an athlete if they are exercising more and sleeping less, with a result in feeling hungry because of the combination. Therefore, examining amount of sleep with energy intake and nutrient composition of an athlete's diet is paramount to assess if they have the necessary fuel for peak performance.

Throughout this study, the aim was to determine the effect(s) of extending an athlete's sleep period by one hour on athletic performance and nutritional behaviors on female track and field athletes. To our knowledge, studies assessing the effects of sleep extension in female 
athletes relating to the impact on physical performance and nutrition behaviors have not been undertaken. 


\section{STUDY OBJECTIVES}

The study's primary objective(s) was to recruit 18 - 24 year old West Virginia University (WVU) female track and field athletes for the SleEP iN study and investigate the effects of sleep extension ( 1 hour more) on performance, as measured by the Wingate Anaerobic Test (WAnT), Psychomotor Vigilance Test (PVT) and Profile of Moods States (POMS) and energy consumption as measured by total kilocalories, percent fat, protein and carbohydrate and total water using a self-report ASA-24 hour dietary multi-pass recall. Further, descriptive baseline anthropometric measures including: height, weight, body mass index (BMI), body fat percentage, waist circumference, blood pressure, and menstrual status were also collected. 


\section{CHAPTER II}

\section{REVIEW OF LITERATURE}

\section{Introduction}

The purpose of this review is to determine the accomplishments and need in current research evaluating the known effects of sleep, both deprivation and extension, as it relates to physical and mental performance, as well as sleep's implications on nutritional behaviors in collegiate athletes.

The databases that were used in the search were PubMed, EbscoHost, Academic Search Complete, CINHAHL with text, MEDLINE, PsycINFO and SPORTDiscus. An initial search with text from 2000 to the present (2014) was done in adult subjects and then extended with further review. Reference lists of relevant reviews and all identified studies were examined and reviewed. Key words used in the search were sleep duration, extension, restriction, deprivation, athletes, nutrition, diet, exercise, physical activity and performance.

\section{Sleep and Physical \& Mental Performance}

Sleep is an essential component of rest and recovery both physically and mentally. The National Sleep Foundation reports that adults should be receiving seven to nine hours of sleep per day ${ }^{(9)}$. According to the National Health Interview Survey performed between 2005 and $2007,30 \%$ of adults reported sleeping six hours or fewer ${ }^{(10)}$. When a person does not receive an adequate amount of sleep, defined on average as seven hours or less per night ${ }^{(11-13)}$, this is termed sleep deprivation ${ }^{(1)}$. Sleep deprivation can lead to anxiety, depression, stress and other psychological problems ${ }^{(2,3,14)}$. In athletes, sleep is important for several reasons; to limit the loss of cognitive and motor abilities, to organize the information received from training and to 
improve alertness and mood, which are needed to excel in performance ${ }^{(4)}$. Athletes are also more prone to physical stress on their bodies, causing a greater need for recovery. Healing is improved by getting adequate sleep ${ }^{(1,15)}$. Some researchers suggest that athletes need more sleep than less active individuals ${ }^{(16)}$ yet, they may be getting less ${ }^{(5)}$. Tsai and Li showed that "fit" individuals slept on average 20 minutes less than their "unfit" counterparts ${ }^{(17)}$. To date, there has been no other study that examined similar effects. Furthermore, college students (18-24) may be more sleep deprived compared to other adults ${ }^{(17)}$. Liguori et al. found college students (ages 18-26) slept an average of 7-8 hours per night yet reported feeling rested when they woke up less than $50 \%$ of the time ${ }^{(18)}$.

Although research evidence supports the view that exercise training helps promote sleep ${ }^{(19)}$, it is possible that participation in sport may hinder the ability to receive quality sleep. Leeder et al. showed Olympic athletes had comparable quantity of sleep to controls (6:55 \pm 0:43 mins vs. 7:11 \pm 0:25 mins) however, significant differences were observed in quality of sleep ${ }^{(20)}$. Athletes had longer sleep latency $(18.2 \pm 16.5 \mathrm{~min}$ vs. $5.0 \pm 2.5 \mathrm{~min})$ and lower sleep efficiency $(80.6 \pm 6.4 \%$ vs. $88.7 \pm 3.6 \%)$ than controls ${ }^{(20)}$. Various factors may alter the efficiency of sleep in these athletes: training close to sleep influencing body temperature ${ }^{(21)}$, traveling and jet lag ${ }^{(22)}$, pre competition worry ${ }^{(23)}$, or balancing life activities and sport. Despite these consequences, data presented by these researchers may be used as a reference for sleep intervention studies on the athlete.

Performance in athletes is highly regulated by the sleep-wake cycle ${ }^{(16)}$. Basic components of exercise such as temperature, flexibility, vigilance, muscular strength, and metabolic functions are driven by the body clock or the circadian cycle ${ }^{(16,24)}$ that may be 
altered with disturbances of sleep. Sleep can be divided into two main states serving different functions; non-rapid eye movement (NREM), and rapid eye movement sleep (REM) ${ }^{(1,16)}$. In NREM, the brain reduces activity and neurons synchronize ${ }^{(16)}$. Additionally, metabolic activity is low and the pituitary gland is releasing growth hormone $(\mathrm{GH})$ in order to stimulate protein synthesis, maintain blood glucose, repair muscle, promote fat burning, and build bone ${ }^{(1,16,25)}$. During REM sleep, the brain becomes very active, motor activity decreases and muscles are in total relaxation ${ }^{(1,16)}$. If athlete's basal sleep is not achieved it can lead to a general decline in performance where they are not as refreshed and alert the following day.

Sleep deprivation has been well-documented with respect to performance in athletes and young adults (ages 18-26) ${ }^{(16,26)}$. It can affect the athlete's ability to perform optimally such as: reduction in cardiovascular performance, reaction time, ability to process information, emotional stability, and metabolic processes ${ }^{(1,27)}$. Azboy and Kaygisiz reported increased resting oxygen uptake $\left(\mathrm{VO}_{2}\right)$ in ten male distance runners, age 17-18 years, during a self-paced treadmill protocol following $25-30$ hours of sleep loss $(P<0.05)^{(12)}$. Ten male volleyball players were also examined and sleep loss significantly decreased time to exhaustion $(P<0.01)$. Another study investigated the effects of one night of sleep deprivation on treadmill endurance in 11 recreationally active young adult males, ages $17-23^{(11)}$. Subjects acted as their own control by completing two randomized trials separated by seven days following normal sleep and 30 hours without sleep. Less distance was covered when subjects were sleep deprived compared to when they slept close to eight hours $(\mathrm{P}=0.02)$. Maximal oxygen uptake $\left(\mathrm{VO}_{2} \max \right)$ was greater in the sleep deprived group following 30 minutes of exercise compared to when they slept eight hours $(P<0.05)$. 
Although these studies examined performance measures based on endurance, a recent crossover design examined 30 hours of sleep deprivation on an intermittent-sprint performance and muscle glycogen ${ }^{(27)}$. Ten male athletes in team sports, ages $18-24$, underwent two consecutive-day experimental trials separated by a normal night's sleep or no sleep. Subjects performed a 30-minute exercise run and 50-minute intermittent-sprint exercise protocol. Muscle biopsies were taken before and after exercise during baseline and intervention trials. The authors reported slower pacing strategies, reduced intermittent-sprint performance, and reduced muscle glycogen following sleep deprivation. Perception was also measured throughout both trials and more negative perceptions following sleep deprivation such as being less alert, less energetic, and more fatigued. While these studies investigated negative consequences of sleep deprivation on psychological and physiological factors, there are studies that reported no affect of sleep loss on these factors ${ }^{(28-30)}$. Hil et al. showed no affect of one night's sleep loss, 25-30 hours, when seven male and seven female college students, ages 1925 , performed to their limit on a cycling test ${ }^{(31)}$. Researchers speculated that the sleep restriction period (one night's sleep loss) might not be enough to show affects on the cycling test. They also noted that a short task (all-out cycling) requires anaerobic, or "quick energy", which may not be affected by sleep deprivation. More research is needed to examine the effects on sleep loss on aerobic and anaerobic energy production during all-out exercise tasks of different durations.

Not all athletes may experience high levels of sleep loss in a small time frame that is simulated in sleep deprivation studies. This suggests that sleep deprivation can accumulate over time ${ }^{(15)}$, referring to the concept of sleep debt. Sleep debt is defined as the accumulated 
sleep that is lost to poor sleep habits, sickness, awakenings from environmental factors or other causes ${ }^{(9)}$ that is registered by the brain ${ }^{(32)}$. Researchers suggests that sleep debt could account for hours of sleep lost that occurred a month ago or a week ago, and it does not resolve spontaneously ${ }^{(32)}$. Walter stated that an athlete who needs eight hours of sleep each night yet receives only six, would incur a substantial amount of sleep debt to hinder performance levels (1). Dement suggests the anecdote is to obtain extra sleep beyond habitual nightly sleep in order to lower sleep debt ${ }^{(32)}$. However, it has been noted that extra sleep can only equivocate to the amount of sleep incurred as a result of sleep debt ${ }^{(32)}$.

In support thereof, a laboratory study of eight adult men examined the effects of duration of time spent with the lights on, regarding mood and emotion for 35 consecutive days ${ }^{(33)}$. During the first seven days, subjects reported baseline sleep of less than 8 hours. Then for 28 days, subjects were in bed in the dark for 14 hours every night. When switched to 14 hours, sleep time increased to 12 hours on the first night then gradually declined. At about midway in the experiment, average nightly sleep was around 8.5 hours. Results showed that subjects entered the study with sleep debt and gradually decreased the amount of accrued debt when extra sleep was given. The gradual decline shows that extra sleep can only be obtainable to the total amount of sleep lost. Equally important, the subject's mood and energy levels increased following extended sleep. Hence, there is a need for extending sleep in athletes to limit their sleep debt.

Although it is understood that sleep deprivation plays a role in under-performance (or poor performance) in athletes ${ }^{(4,34)}$, there is little research that shows the impact of sleep extension $^{(32,35-38)}$. Several studies have reported adverse reactions with increased night's sleep 
${ }^{(39-41)}$. In one study, twelve college students performed a pinball task after normal and extended sleep of two hours. However, there were decrements in reaction time and average pinball score after extended sleep which the researchers attributed the effect to increased wakefulness in the extended sleep condition ${ }^{(39)}$. Harrison and Horne reported reductions in auditory vigilance and increased Multiple Sleep Latency (MSLT) scores following 10 hours of extended sleep for 14 days in healthy college students ${ }^{(40)}$. In examining reaction time on 61 volunteers following three, five, seven, and nine hours in bed for seven consecutive days ${ }^{(41)}$, those who slept nine hours showed no improvement in performance, although it is possible that extra sleep was not substantial enough to counterbalance the sleep debt incurred.

Alternatively, other studies report benefits of sleep extension in healthy young adults ${ }^{(42,}$ 43). Roehrs et al. found significant improvements in Multiple Sleep Latency Test (MSLT) and reaction times after extending bedtime to 10 hours for six consecutive days ${ }^{(43)}$. Recently, researchers investigated daytime alertness, vigilance and mood in fifteen healthy female and male college students, ages 18-23. Significant increases were reported in MSLT and PVT scores, and improvements to mood using the POMS questionnaire when subjects were encouraged to sleep as much as possible ${ }^{(38)}$. Even a small amount of extra sleep such as a nap has been shown to improve mood and vigilance levels. Hayashi et al. examined seven young adults (age 20-21), who took a 20 minute nap and were tested on mood, performance and self-rating on performance ${ }^{(44)}$. Improved subjective sleepiness, performance level and self-confidence on task performance were seen following the nap. Pierce et al. showed greater ability to use oxygen more efficiently, lower $\mathrm{VO}_{2}$, through the first two stages of a graded exercise test (Bruce Protocol) when subjects received a nap lasting $60-90$ minutes ${ }^{(37)}$. The authors speculated that 
the participants had decreased physiological arousal upon awakening from a bout of sleep.

Therefore it is possible that the subjects given a nap were less anxious in the early stages of the protocol and were able to decrease $\mathrm{VO}_{2}$.

While most sleep extension research observes the relationship between extra sleep and cognitive functioning, little explore the effects on physical performance. Only one study examined sleep extension on athletic performance using performance measures outside the laboratory ${ }^{(36)}$. At the Stanford Sleep Disorders Clinic and Research Laboratory, eleven healthy male college basketball players maintained their habitual sleep patterns for 2-4 weeks followed by a 5-7 week sleep extension period with a goal of 10 hours of sleep, including naps. Measures of athletic performance specific to basketball were determined. In addition, reaction time, daytime sleepiness, and mood were monitored. A faster timed sprint $(P<0.001)$, improvements in shooting accuracy $(P<0.001)$, as well as decreased reaction times and sleepiness scores $(P<$ 0.01) were seen following sleep extension. Subjects also experienced increased vigor and decreased fatigue with sleep extension $(P<0.001)$. Investigators concluded that extending sleep in healthy collegiate basketball players leads to optimal performance; the only limitation being there was no control group. Although much of the research conducted on sleep extension and performance illustrate that getting enough sleep is important for athletes, the precise definition of how much sleep is enough and what measures of performance should be used does not exist and therefore, more research is needed.

\section{See Table 1 for review of studies.}


Table 1: Sleep and Performance Research Articles

\begin{tabular}{|c|c|c|c|c|}
\hline Title and Author(s) & Participants (n) & Objective(s) & Measures/Tools & Results/Conclusions \\
\hline \multicolumn{5}{|l|}{ Sleep Extension } \\
\hline $\begin{array}{l}\text { The effects of an } \\
\text { acute bout of } \\
\text { sleep on running } \\
\text { economy and VO2 } \\
\text { max. } \\
\text { Pierce et al. (1992) }\end{array}$ & $\begin{array}{l}\text { Seven male, } \\
\text { healthy, active } \\
\text { volunteers (age } \\
23 \pm 6.3 \text { years) }\end{array}$ & $\begin{array}{l}\text { Investigate the effects of } \\
\text { an acute bout of sleep on } \\
\text { submaximal (running } \\
\text { economy) and maximal } \\
\text { oxygen consumption. }\end{array}$ & $\begin{array}{l}\text { Acute sleep } \\
\text { bouts (60-90 } \\
\text { minutes) took } \\
\text { place in a } \\
\text { laboratory; } \\
\text { Bruce treadmill } \\
\text { protocol; RER, } \\
\text { spirometry } \\
\text { techniques }\end{array}$ & $\begin{array}{l}\text { No difference between } \\
\text { groups for running } \\
\text { economy or VO2. Those } \\
\text { who received the 1-hour } \\
\text { sleep bout had greater } \\
\text { running economy through } \\
\text { the first two stages of the } \\
\text { protocol, while the } \\
\text { control group yielded a } \\
\text { greater running economy } \\
\text { throughout the remaining } \\
\text { stages }\end{array}$ \\
\hline $\begin{array}{l}\text { A Two-Week Sleep } \\
\text { Extension in Sleepy } \\
\text { Normals. } \\
\text { Roehrs et al. } \\
(1996)\end{array}$ & $\begin{array}{l}34 \text { healthy men } \\
\text { and women } \\
\text { (age } 21-35 \text { ) }\end{array}$ & $\begin{array}{l}\text { Assess the effects of } \\
\text { sleep extension in sleepy } \\
\text { normals. The study } \\
\text { extended bedtime to } 10 \\
\text { hours for a 2-week } \\
\text { period and used a sleepy } \\
\text { control group } \\
\text { maintained on their own } \\
\text { habitual sleep schedules } \\
\text { for the 2-week period. }\end{array}$ & $\begin{array}{l}\text { Polysomnograp } \\
\text { hy, sleep logs, } \\
\text { Multiple Sleep } \\
\text { Latency Test } \\
\text { (MLST) }\end{array}$ & $\begin{array}{l}\text { Those who extended their } \\
\text { sleep } \uparrow \text { sleep latency } \\
\text { relative to those who } \\
\text { maintained habitual } \\
\text { sleep. The } \uparrow \text { in sleep } \\
\text { latency was associated } \\
\text { with a gradual decline in } \\
\text { sleep efficiency over the } \\
14 \text { nights. Those showing } \\
\text { no increase in average } \\
\text { daily sleep latency had an } \\
\text { immediate drop in sleep } \\
\text { efficiency when bedtime } \\
\uparrow \text { to } 10 \text { hours, suggesting } \\
\text { unable to sleep longer } \\
\text { during extension. } \\
\text { Removed sleep debt. }\end{array}$ \\
\hline $\begin{array}{l}\text { Long-term } \\
\text { extension to sleep- } \\
\text { Are we really } \\
\text { chronically sleep } \\
\text { deprived? } \\
\text { Harrison and } \\
\text { Horne (1996) }\end{array}$ & $\begin{array}{l}\text { Eleven subjects } \\
\text { (seven women, } \\
\text { four men; } \\
M=23.6 \text { years } \\
\text { old; range=18- } \\
36 \text { years) }\end{array}$ & $\begin{array}{l}\text { Investigating the effects } \\
\text { of a prolonged period of } \\
\text { extended nocturnal } \\
\text { sleep ( } 10 \text { hours a night } \\
\text { for } 14 \text { consecutive } \\
\text { nights) in a home setting } \\
\text { in terms of a number of } \\
\text { specific questions: does } \\
\text { longer nighttime sleep } \\
\text { lead o less daytime }\end{array}$ & $\begin{array}{l}\text { Multiple Sleep } \\
\text { Latency Test, } \\
\text { vigilance } \\
\text { performance } \\
\text { (Wilkinson } \\
\text { Auditory } \\
\text { Vigilance Task), } \\
\text { subjective } \\
\text { daytime, } \\
\text { sleepiness }\end{array}$ & $\begin{array}{l}\text { During extended sleep, } \\
\text { subject slept longer, but } \\
\text { sleep latency and interim } \\
\text { wakefulness } \downarrow \text {. Extended } \\
\text { sleep produced no } \\
\text { improvements to mood or } \\
\text { subjective sleepiness. } \\
\text { Vigilance test showed a } \\
\text { small but significant } \downarrow \text { in } \\
\text { reaction time following }\end{array}$ \\
\hline
\end{tabular}




\begin{tabular}{|c|c|c|c|c|}
\hline & & $\begin{array}{l}\text { sleepiness? Does this } \\
\text { coincide with improved } \\
\text { performance? Can this } \\
\text { be sustained for many } \\
\text { nights? Is there } \\
\text { increased daytime } \\
\text { alertness, and if so, any } \\
\text { potential benefit to } \\
\text { daytime functioning? }\end{array}$ & $\begin{array}{l}\text { (Karolinska } \\
\text { Sleepiness } \\
\text { Scale), } \\
\text { mood(POMS) } \\
\text { and nighttime } \\
\text { sleep. wrist } \\
\text { actigraphy, } \\
\text { sleep diary }\end{array}$ & $\begin{array}{l}\text { extended sleep compared } \\
\text { to baseline and recovery } \\
\text { sleep. Multiple Sleep } \\
\text { Latency Test scores } \downarrow \\
\text { during extended sleep. }\end{array}$ \\
\hline $\begin{array}{l}\text { The effects of a } 20 \\
\text { minute nap in the } \\
\text { mid-afternoon on } \\
\text { mood, } \\
\text { performance and } \\
\text { EEG activity. } \\
\text { Hayashi et al. } \\
\text { (1999) }\end{array}$ & $\begin{array}{l}\text { Seven } \\
\text { university } \\
\text { students ( } 3 \\
\text { male and } 4 \\
\text { female) with } \\
\text { good health } \\
\text { participated } \\
\text { (20-21 years) }\end{array}$ & $\begin{array}{l}\text { To examine the effects of } \\
\text { a } 20 \text { minute nap in the } \\
\text { mid-afternoon on mood, } \\
\text { performance and EEG } \\
\text { activities. }\end{array}$ & $\begin{array}{l}\text { Sleep logs, } \\
\text { Sleep Habit } \\
\text { Inventory and } \\
\text { Morning- } \\
\text { Evening } \\
\text { Questionnaire, } \\
\text { Performance } \\
\text { Tasks (logical } \\
\text { reasoning, } \\
\text { addition, visual } \\
\text { detection, } \\
\text { auditory } \\
\text { vigilance), EEG }\end{array}$ & $\begin{array}{l}\text { A } 20 \text { minute nap } \\
\text { improved subjective } \\
\text { sleepiness, performance } \\
\text { level and self confidence } \\
\text { on their task } \\
\text { performance. The nap } \\
\text { suppressed EEG alpha } \\
\text { activity during eye-open } \\
\text { wakefulness }\end{array}$ \\
\hline $\begin{array}{l}\text { The impact of } \\
\text { extended sleep on } \\
\text { daytime alertness, } \\
\text { vigilance, and } \\
\text { mood. } \\
\text { Kamdar et al. } \\
(2004)\end{array}$ & $\begin{array}{l}\text { Fifteen healthy } \\
\text { college } \\
\text { students (4 } \\
\text { women, } 11 \\
\text { men) aged 18- } \\
23 \text { years old. }\end{array}$ & $\begin{array}{l}\text { To measure the effects } \\
\text { of prolonged sleep } \\
\text { extension (sleep as much } \\
\text { as possible) on daytime } \\
\text { alertness, vigilance, and } \\
\text { moos in healthy young } \\
\text { adults. }\end{array}$ & $\begin{array}{l}\text { Epworth } \\
\text { Sleepiness } \\
\text { Scale, } \\
\text { wristwatch-like } \\
\text { actigraphs } \\
\text { (Ambulatory } \\
\text { Monitoring), } \\
\text { sleep logs, } \\
\text { Multiple Sleep } \\
\text { Latency, } \\
\text { Psychomotor } \\
\text { Vigilance Test } \\
\text { (PVT), Profile of } \\
\text { Moods }\end{array}$ & $\begin{array}{l}5 \text { of the } 8 \text { PVT measures } \\
\text { improved with sleep } \\
\text { extension with respect to } \\
\text { baseline. POMS vigor and } \\
\text { fatigue scores showed a } \\
\text { similar improvement. } 7 \\
\text { subjects achieved a MSLT } \\
\text { score or } 20 \text { and } 6 \text { subjects } \\
\text { showed substantial } \\
\text { improvements while } 2 \\
\text { subjects obtained little } \\
\text { extra sleep and showed } \\
\text { little or no improvements. } \\
\text { The extension group had } \\
\text { exceptional } \\
\text { improvements in vigilance } \\
\text { and POMS ratings. }\end{array}$ \\
\hline $\begin{array}{l}\text { The Effects if Sleep } \\
\text { Extension of } \\
\text { Athletic } \\
\text { Performance of }\end{array}$ & $\begin{array}{l}\text { Eleven healthy } \\
\text { Stanford } \\
\text { University male } \\
\text { varsity }\end{array}$ & $\begin{array}{l}\text { To investigate the effects } \\
\text { of sleep extension ( } 10 \\
\text { hours) over multiple } \\
\text { weeks (5-7) on specific }\end{array}$ & $\begin{array}{l}\text { Actigraphy } \\
\text { (Actiware } \\
\text { software), sleep } \\
\text { journals, }\end{array}$ & $\begin{array}{l}\text { Subjects demonstrated a } \\
\text { faster timed sprint } \\
\text { following sleep extension. } \\
\text { Shooting accuracy }\end{array}$ \\
\hline
\end{tabular}




\begin{tabular}{|c|c|c|c|c|}
\hline $\begin{array}{l}\text { Collegiate } \\
\text { Basketball Players. } \\
\text { Mah et al. (2011) }\end{array}$ & $\begin{array}{l}\text { basketball } \\
\text { players (mean } \\
19.4 \pm 1.4 \\
\text { years) }\end{array}$ & $\begin{array}{l}\text { measures of athletic } \\
\text { performance as well as } \\
\text { reaction time, mood, and } \\
\text { daytime sleepiness }\end{array}$ & $\begin{array}{l}\text { Epworth } \\
\text { Sleepiness } \\
\text { Scale, POMS, } \\
\text { performance } \\
\text { measures } \\
\text { (timed sprint } \\
\text { and shooting } \\
\text { accuracy), PVT }\end{array}$ & $\begin{array}{l}\text { improved and PVT } \\
\text { reaction time and ESS } \downarrow \\
\text { following sleep extension. } \\
\text { POMS scored improved } \\
\text { with } \uparrow \text { vigor and } \downarrow \\
\text { fatigue subscales. } \\
\text { Subjects also reported } \\
\text { improved overall ratings } \\
\text { of physical and mental } \\
\text { well-being during } \\
\text { practices and games. }\end{array}$ \\
\hline \multicolumn{5}{|l|}{ Sleep Restriction } \\
\hline $\begin{array}{l}\text { Effects of Total } \\
\text { Sleep Loss on } \\
\text { Sleep Tendency. } \\
\text { Carskadon and } \\
\text { Dement (1979) }\end{array}$ & $\begin{array}{l}\text { Six } \\
\text { undergraduate } \\
\text { volunteers (2- } \\
\text { women, 4- } \\
\text { men) ages 18- } \\
21 \text { years }\end{array}$ & $\begin{array}{l}\text { Validate the multiple } \\
\text { sleep latency approach } \\
\text { to measuring daytime } \\
\text { function and to } \\
\text { demonstrate the relative } \\
\text { sensitivity of sleep } \\
\text { tendency to sleep loss }\end{array}$ & $\begin{array}{l}\text { Wilkinson } \\
\text { Addition Test } \\
\text { and the Serial } \\
\text { Alteration Task, } \\
\text { a mood scale, } \\
\text { Stanford } \\
\text { Sleepiness } \\
\text { Scale, Multiple } \\
\text { Sleep Latency } \\
\text { Tests }\end{array}$ & $\begin{array}{l}\text { Wilkinson test } \downarrow \\
\text { following sleep loss and } \\
\text { recovered after one or } \\
\text { two full nights of sleep. } \\
\text { Performance of Alteration } \\
\text { task } \downarrow \text { following sleep } \\
\text { loss. Mood and sleepiness } \\
\text { declined during sleep loss. } \\
\text { Sleep latency fell to about } \\
1 \text { minute and remained } \\
\text { low during the sleep loss } \\
\text { period. Baseline levels } \\
\text { were not achieved until } \\
\text { the second sleep recovery } \\
\text { day. }\end{array}$ \\
\hline $\begin{array}{l}\text { Meta-Analysis of } \\
\text { the Relationship } \\
\text { Between Total } \\
\text { Sleep Deprivation } \\
\text { and Performance. } \\
\text { Koslowsky and } \\
\text { Babkoff (1991) }\end{array}$ & $\begin{array}{l}70 \text { studies } \\
\text { found that } \\
\text { testes total } \\
\text { sleep } \\
\text { deprivation } \\
\text { (TSD). } 27 \\
\text { studies with } \\
429 \text { subjects } \\
\text { met the } \\
\text { criteria. }\end{array}$ & $\begin{array}{l}\text { To test general notions } \\
\text { and to provide a } \\
\text { numerical measure of } \\
\text { strength of the } \\
\text { relationship between } \\
\text { TSD and performance. }\end{array}$ & $\begin{array}{l}\text { Manual } \\
\text { Examination of } \\
\text { al Psychological } \\
\text { Abstracts } \\
\text { between 1969- } \\
1983 \text { and a } \\
\text { computerized } \\
\text { search between } \\
\text { 1984-1988. }\end{array}$ & $\begin{array}{l}\text { The results are consistent } \\
\text { with the "lapse } \\
\text { hypothesis". The } \\
\text { correlations implied that } \\
\text { under long TSD or work- } \\
\text { paced stimuli rather than } \\
\text { short TSD or self-paced } \\
\text { stimuli, subjects are more } \\
\text { likely to be affected by } \\
\text { sleep loss }\end{array}$ \\
\hline $\begin{array}{l}\text { Patterns of } \\
\text { performance } \\
\text { degradation and } \\
\text { restoration during } \\
\text { sleep restriction }\end{array}$ & $\begin{array}{l}66 \text { volunteers } \\
\text { (16-women, } \\
\text { age } 24-55, \\
\text { mean =43 } \\
\text { years; and 55- }\end{array}$ & $\begin{array}{l}\text { Determine the effects of } \\
\text { several levels of } \\
\text { restricted }(3,5 \text {, or } 7 \text { for } 7 \\
\text { days) and one level of } \\
\text { augmented sleep ( } 9\end{array}$ & $\begin{array}{l}\text { Psychomotor } \\
\text { Vigilance Test, } \\
\text { Polysomnograp } \\
\text { hy, Night-time } \\
\text { sleep recorded }\end{array}$ & $\begin{array}{l}3 \text { hour group-relapses } \uparrow \\
\text { and speed } \downarrow \text { in the PVT. } \\
\text { Speed and lapses } \\
\text { recovered during the } \\
\text { recovery period. }\end{array}$ \\
\hline
\end{tabular}




\begin{tabular}{|c|c|c|c|c|}
\hline $\begin{array}{l}\text { and subsequent } \\
\text { recovery: a dose } \\
\text { dependent study. } \\
\text { Belenky et al. } \\
(2002)\end{array}$ & $\begin{array}{l}\text { men, age 24- } \\
62, \text { mean = } 37 \\
\text { years) }\end{array}$ & $\begin{array}{l}\text { hours for } 7 \text { days) over } \\
\text { seven consecutive days } \\
\text { on objective and } \\
\text { subjective alertness and } \\
\text { objective performance; } \\
\text { and determine the } \\
\text { extent to which } 3 \text { days of } \\
\text { subsequent recovery } \\
\text { sleep ( } 8 \text { hours) restored } \\
\text { performance and } \\
\text { alertness to baseline } \\
\text { levels. }\end{array}$ & $\begin{array}{l}\text { by six } \\
\text { technicians, } \\
\text { sleep latency } \\
\text { test, Stanford } \\
\text { Sleepiness Scale }\end{array}$ & $\begin{array}{l}5 \text { and } 7 \text { hour group-speed } \\
\text { initially declined then } \\
\text { stabilized and lapses } \uparrow \text { in } \\
5 \text { hour group. Recovery } \\
\text { remained stable for speed } \\
\text { and lapses in the } 5 \text { hour } \\
\text { group. } \\
9 \text { hour group-speed and } \\
\text { lapses remained at } \\
\text { baseline for both } \\
\text { augmentation and } \\
\text { recovery periods }\end{array}$ \\
\hline $\begin{array}{l}\text { The Effects of } \\
\text { Sleep Restriction } \\
\text { and Extension on } \\
\text { School-Age } \\
\text { Children: } \\
\text { What a difference } \\
\text { and hour makes. } \\
\text { Sadeh et al. (2003) }\end{array}$ & $\begin{array}{l}77 \text { children } \\
\text { (age: } M=10.6 \\
\text { years; range = } \\
\text { 9.1-12.2 years) } \\
\text { 39-boyrs 38- } \\
\text { girls }\end{array}$ & $\begin{array}{l}\text { Assess the effects of } \\
\text { modest sleep restriction } \\
\text { or extension ( } 1 \text { hour for } \\
\text { one day) on children's } \\
\text { neurobehavioral } \\
\text { functioning (NBF) }\end{array}$ & $\begin{array}{l}\text { Actigraphy, } \\
\text { Daily sleep- } \\
\text { wake diaries, } \\
\text { NBF by } \\
\text { Neuropsycholog } \\
\text { ical Evaluation } \\
\text { System }\end{array}$ & $\begin{array}{l}\text { Sleep restriction improved } \\
\text { sleep quality but } \\
\downarrow \text { reported alertness; } \\
\text { Sleep extension improved } \\
\text { performance on memory } \\
\text { and reaction time. }\end{array}$ \\
\hline $\begin{array}{l}\text { Effects of sleep } \\
\text { deprivation on } \\
\text { cardiorespiratory } \\
\text { functions of the } \\
\text { runners } \\
\text { and volleyball } \\
\text { players during rest } \\
\text { and exercise. } \\
\text { Azboy and Kaygisiz } \\
\text { (2008) }\end{array}$ & $\begin{array}{l}10 \text { male } \\
\text { distance } \\
\text { runners (age } \\
18.1 \pm 0.35 \text { ) and } \\
\text { volleyball } \\
\text { players (age } \\
17.8 \pm 0.36 \text { ) }\end{array}$ & $\begin{array}{l}\text { Investigated the possible } \\
\text { effect of one night sleep } \\
\text { loss on the resting } \\
\text { spirometric, resting and } \\
\text { exercise } \\
\text { cardiorespiratory } \\
\text { parameters of the } \\
\text { runners and volleyball } \\
\text { players }\end{array}$ & $\begin{array}{l}\text { Spirometric } \\
\text { tests at rest and } \\
\text { then } \\
\text { incremental test } \\
\text { on ergometer }\end{array}$ & $\begin{array}{l}\text { Sleep loss } \uparrow \text { resting VO2 } \\
\text { in the runners and resting } \\
\text { VCO2 in both the runners } \\
\text { and volleyball players. HR, } \\
\mathrm{R}, \mathrm{VE} \text {, and } \mathrm{SaO} 2 \\
\text { unchanged in both } \\
\text { groups. Sleep loss } \downarrow \text { time } \\
\text { to exhaustion in the } \\
\text { volleyball players. Sleep } \\
\text { loss did not alter HR, } \\
\text { SaO2, VO2, VCO2, and R, } \\
\text { but } \downarrow \text { exercise VE in both } \\
\text { groups. }\end{array}$ \\
\hline $\begin{array}{l}\text { One night of sleep } \\
\text { deprivation } \\
\text { decreases } \\
\text { treadmill } \\
\text { endurance } \\
\text { performance. } \\
\text { Oliver et al. (2009) }\end{array}$ & $\begin{array}{l}11 \\
\text { recreationally } \\
\text { active healthy } \\
\text { males (Mean } \\
\text { (SD): age } 20 \text { (3) } \\
\text { years) }\end{array}$ & $\begin{array}{l}\text { To test the hypothesis } \\
\text { that one night of sleep } \\
\text { deprivation ( } 30 \text { hours } \\
\text { w/o sleep) will impair } \\
\text { pre-loaded } 30 \text { minute } \\
\text { endurance performance } \\
\text { and alter the cardio- } \\
\text { respiratory, }\end{array}$ & $\begin{array}{l}\text { Continuous } \\
\text { incremental } \\
\text { exercise test on } \\
\text { a motorized } \\
\text { treadmill; DXA; } \\
\text { Accelerometer } \\
\text { (ActiGraph LLC, }\end{array}$ & $\begin{array}{l}\text { Less distance covered } \\
\text { after sleep deprivation } \\
\text { compared with control. } \\
\text { Sleep deprivation did not } \\
\text { alter core temperature at } \\
\text { rest or thermoregulatory } \\
\text { responses during the } \\
\text { preload. Respiratory }\end{array}$ \\
\hline
\end{tabular}




\begin{tabular}{|c|c|c|c|c|}
\hline & & $\begin{array}{l}\text { thermoregulatory and } \\
\text { perceptual responses to } \\
\text { exercise. }\end{array}$ & Florida) & $\begin{array}{l}\text { parameters, RPE and } \\
\text { speed were not different } \\
\text { between trials during } \\
\text { preload or distance test. }\end{array}$ \\
\hline $\begin{array}{l}\text { Intermittent-Sprint } \\
\text { Performance and } \\
\text { Muscle Glycogen } \\
\text { after } 30 \text { h of } \\
\text { Sleep Deprivation. } \\
\text { Skein et al. (2010) }\end{array}$ & $\begin{array}{l}\text { Ten male team- } \\
\text { sport athletes } \\
\text { (age } 21 \pm 3 \text { years }\end{array}$ & $\begin{array}{l}\text { To determine the effects } \\
\text { of } 30 \text { hours of sleep } \\
\text { deprivation on } \\
\text { consecutive-day } \\
\text { intermittent-sprint } \\
\text { performance and muscle } \\
\text { glycogen content }\end{array}$ & $\begin{array}{l}30 \text { minute } \\
\text { graded exercise } \\
\text { run (GXR) on a } \\
\text { motorized } \\
\text { treadmill and } \\
\text { 50-minute } \\
\text { intermittent- } \\
\text { sprint exercise } \\
\text { protocol; } \\
\text { Maximal } \\
\text { isometric } \\
\text { voluntary } \\
\text { contraction } \\
\text { (MVC), urine } \\
\text { samples, muscle } \\
\text { biopsies, sleep } \\
\text { diaries and } \\
\text { Actiwatch } \\
\text { actigraphs, } \\
\text { POMS }\end{array}$ & $\begin{array}{l}\text { Mean sprint times were } \\
\text { slower during trial } 2 \text { sleep } \\
\text { deprivation compared } \\
\text { with trial one sleep } \\
\text { deprivation or trial } 2 \\
\text { baseline. Distance } \\
\text { covered during self-paced } \\
\text { exercise } \downarrow \text { during trial } 2 \\
\text { sleep deprivation during } \\
\text { the initial } 10 \text { min } \\
\text { compared with trial } 1 \\
\text { sleep deprivation and } \\
\text { during the final } 10 \\
\text { minutes compared to trial } \\
\quad 2 \text { control. Muscle } \\
\text { glycogen was lower in } \\
\text { trial } 2 \text { sleep deprivation } \\
\text { compared to trial } 2 \\
\text { control. Sleep loss } \\
\text { negatively affected PoMs } \\
\text { ratings. }\end{array}$ \\
\hline
\end{tabular}




\section{Sleep and Nutrition}

Due to the high prevalence of obesity and the rapid decline of sleep in U.S. citizens, many researchers have examined the correlation between sleep deprivation and obesity in the non-active healthy population ${ }^{(45-51)}$. In a six-year longitudinal study of 276 adults, age 21-64 years old, investigators examined the relationship between fat gain, body weight and sleep ${ }^{(50)}$. Individuals who slept 5-6 hours instead of the normal 7-8 hours gained $1.98 \mathrm{~kg}$ more $(95 \% \mathrm{Cl}$ : 1.16-2.82) weight over the six years. In a meta-analysis by Cappuccio et al., the relationship between short sleep ( $\leq 5$ hours for adults) duration and obesity (BMI $\geq 30 \mathrm{~kg} / \mathrm{m}^{2}$ for adults) was investigated $^{(47)}$. In order to estimate the quantitative relation between short sleep duration and obesity, an odds ratio (OR) was obtained. For adults, 15 year and older, the pooled ratio between short sleep and obesity was 1.55 (95\% Cl: 1.43-1.68, $\mathrm{P}<0.001)$ which suggested an increased risk of being obese or gaining weight with short sleep. These findings led many researchers to investigate the underlying causes of sleep duration on body weight regulation.

Sleep loss has been linked to many pathways associated with obesity: increased ghrelin and decreased leptin levels, increased time to eat and lower energy expenditure due to increased fatigue and decreased physical activity ${ }^{(45)}$. However, little research explores the association of sleep loss to obesity ${ }^{(45)}$ yet some have examined the effects of sleep deprivation on the metabolic and endocrine systems ${ }^{(45,52-57)}$. Redwine et al. investigated the effects of sleep deprivation on interleukin-6 (IL-6), growth hormone (GH), cortisol, and melatonin levels in humans ${ }^{(57)}$. IL-6 is a pro-inflammatory cytokine released by macrophages in response to infections to help aid in the immune response ${ }^{(57)}$. It also stimulates the pituitary gland of the hypothalamus to secrete cortisol and $\mathrm{GH}^{(58)}$; which regulate metabolism and anabolism, 
respectively. Decreased IL-6 and GH was seen with sleep loss, which may affect the integrity of the immune system and possibly increase the risk of inflammatory diseases ${ }^{(57)}$. On the other hand, decreases in GH with sleep loss can hinder fat breakdown, protein and bone growth as well as increase muscle mass, which can diminish athletic performance levels. Investigators showed no changes in cortisol levels with sleep loss. The researchers argued that IL-6 may be one of several physiological factors stimulating adrenal cortisol production during the night. In contrast, another study reported different results ${ }^{(52)}$. Six, male, healthy volunteers, 18-21 years old, were deprived of continuous, 72 hours of sleep and underwent a series of performance tasks of minimal physical activity and mostly cognitive in nature, along with collecting urine samples $^{(52)}$. Following sleep deprivation, urinary cortisol levels decreased slightly (33 $\left.\mu \mathrm{g} / \mathrm{L}\right)$, however there was no significant effect between the different days of sleep deprivation and urinary cortisol $(P>0.05)$. Urinary glucose declined steadily over the days $(P<0.05)$ and urea excretion increased significantly from 48 and 72 hours of sleep deprivation compared to the control group $(P<0.05)$. The researchers suggested that sleep deprivation required glucose be obtained from protein to meet metabolic demands. However, a limitation of the study was that food, water intake, and physical activity were not monitored, which could affect protein catabolism and increased urea excretion. Redwine et al. also provided no indication of having measured or monitored food intake ${ }^{(57)}$.

Sleep has been shown to play an important role in energy balance, whereby the loss of sleep promotes changes in hormonal signals that influence hunger and satiety ${ }^{(55,56,59)}$. These hormones are leptin and ghrelin, which reduce and stimulate appetite respectively ${ }^{(60)}$. Taheri conducted a large scale study on 1,024 male and female volunteers, ages 44 to 60 , to 
investigate sleep duration on metabolic hormones and body mass index (BMI). Sleeping less than 8 hours was associated with low serum leptin levels ( $P=0.01$ for slope) and high serum ghrelin levels $\left(P<0.01\right.$ for slope ${ }^{(56)}$. Researchers also found lower predicted serum leptin levels (15.5\%) and higher predicted serum ghrelin (14.9\%) levels for nocturnal sleep of 5 hours versus 8 hours independent of BMI. In a crossover study with a goal to determine whether sleep loss alters appetite regulation in 12 healthy men, 20 to 24 years old, ${ }^{(55)}$ caloric intake and physical activity were controlled using a research setting and two groups of participants were asked to undergo two days of sleep extension (10 hours in bed) or sleep restriction (4 hours in bed) in randomized order. After six weeks of subjects maintaining normal sleep habits, subjects were brought back in the lab to be crossed to the other intervention group. Ratings of hunger and appetite were reported and blood serum leptin and ghrelin were taken. Compared to those who spent 10 hours in bed, subjects who slept 4 hours had $18 \%$ lower serum leptin $(P<0.05)$ and $28 \%$ higher serum ghrelin $(P<0.05)$. Sleep restriction relative to sleep extension was associated with $24 \%$ increase in hunger ratings $(P<0.01)$ and $23 \%$ increase in appetite ratings $(P=0.01)$. Additionally, an increase in hunger was proportional to the increase in ghrelin-toleptin ratio $(r=0.87)$. Altogether, these findings suggest that sleep loss can affect hunger and appetite. Although obesity may not be an issue for athletes, these individuals may feel hungry as a consequence of expending more calories than they are eating, or feeling hungry from the imbalance of satiety hormones. Either instances were found to contribute to engaging in unhealthful behaviors to satisfy appetite.

College students report frequently engaging in unhealthful behaviors: poor sleeping habits, frequent drinking, smoking, risky sexual behaviors, and disordered eating patterns ${ }^{(61-64)}$. 
In examining sleep behaviors, college students have reportedly slept less than the recommended amount of $8-10$ hours $(18,61,65)$, leading to detrimental effects on academic performance and other performance. College students' nutritional behaviors are of interest due to their unique circumstances such as: dining hall food choice, cost, convenience, lack of cooking skills or utensils and location. One study examined 101 men and 158 women, 19-24 years old, enrolled at a mid-western university. It observed sex differences in fast-food consumption, nutrition self-assessments, and beliefs ${ }^{(63)}$. Males ate at fast food restaurants more often than females $(P<0.01)$, where $74 \%$ of males and $60 \%$ of females indicated eating out 1 to 3 times a week. When asked if nutrition content of food was important, there was a significant difference $(\mathrm{P}<0.001)$ where $51 \%$ of females and $24 \%$ of males strongly agreed. Dietary behaviors among female college students is important, with high prevalence of these individuals developing eating disorders in order to maintain low body weight ${ }^{(64,66,67)}$. One study examined the prevalence of eating disorders and disordered eating among 204 female collegiate athletes from 17 different sports in 3 universities ${ }^{(66)}$. Twenty-five percent of the athletes experienced disordered eating and $2 \%$ had an actual eating disorder ( 3 classified as having subthreshold bulimia and 1 as having nonbinging bulimia).

Proper nutrition has been shown to enhance exercise performance where adequate energy consumption is needed to maintain appropriate weight and body composition, but also fuel performance ${ }^{(6)}$. Although this is evident, many investigators have demonstrated low energy intake of athletes; carbohydrate intake less than $60 \%$ and high fat intake greater than $30 \%$ of total energy ${ }^{(68-70)}$. Cole et al. examined the dietary practices of 28 Division I football athletes and found energy intake to be significantly lower $(P<0.05)$ than the estimated 4,000 to 
$5,300 \mathrm{kcal}$ amount recommended ${ }^{(71)}$. A similar study examined the same population and found that athletes were eating 3.6 times per day, eating out 4.8 times per week and consuming a minimal amount of fluid throughout a workout ${ }^{(72)}$. This evidence supports the importance of investigating the athletes' nutritional behaviors and how sleep may be a factor impacting nutritional choices.

Little research has examined the impact of sleep and its role on nutritional behaviors ${ }^{\text {(73- }}$ ${ }^{78)}$, whereby most have showed inconsistent results. Schmid et al. examined sleep loss (4 hours of sleep for two consecutive days )on physical activity and food in 15 healthy men, ages 20-40 (76). Short-term sleep loss did not significantly alter food intake or feeling of hunger and appetite. The investigators argued that their results with unchanged serum leptin and plasma ghrelin are attributed to the amount of sleep duration between conditions and that other investigators showed elevated plasma ghrelin concentrations after sleep restriction because of study design differences. The study by Schmid et al. may have had too small differences in sleep duration between conditions to elicit detectable effects on concentrations of plasma ghrelin and serum leptin. In contrast, Nishiura et al. investigated dietary patterns and short sleep duration on healthy Japanese male workers, ages $40-59^{(78)}$. Participants who slept less than six hours compared to those who slept seven to eight hours were more likely to skip breakfast $(P=0.01)$, eat out $(P<0.001)$, and had a higher preference for fatty foods $(P<0.01)$. Similarly, participants, ages 18-71, who were late sleepers (midpoint of $\geq 5: 30 \mathrm{am}$ ) consumed more calories after 8:00 pm $(P<0.01)$, had higher fast-food $(P<0.05)$, full-calorie $(P<0.001)$ and lower fruit and vegetable consumption $(P<0.001)$ than normal sleepers (midpoint of $<5: 30$ am) (77). 
Recently, investigators have found an increase in fat intake when sleep duration was less than eight hours ${ }^{(73,74)}$. Weiss et al. reported adolescents, ages 16 to 19 , who slept less than eight hours on weekdays consumed higher proportions of calories from fats (35.9 $\pm 6.7 \%)$ and lower proportions of calories from carbohydrates $(49.6 \pm 8.2 \%)$ compared to those who slept eight or more hours $(33.2 \pm 6.9 \% \mathrm{P}=0.004 ; 53.3 \pm 8.3 \% \mathrm{P}=0.001$, respectively). Another study investigated dietary nutrients related to objective and subjective sleep and napping in 459 post-menopausal women for one week sleep duration ${ }^{(74)}$. Total sleep time with actigraph measurements was negatively associated with fat intake $(P=0.0004)$, however a large number of comparisons would result in stricter Type-1 error control. These researchers suggest that amount of sleep may affect energy consumption and overall dietary choices, but the influence of sleep deprivation on energy intake remains unclear, especially for athletes.

If sleep deprivation causes individuals to make poor nutritional choices and may lead to obesity, then the impact of sleep extension on weight, caloric intake, energy expenditure, the endocrine system and body composition is also of interest. One such study is currently investigating the topic, by increasing sleep (30-60 minutes per night) in obese individuals ${ }^{(79)}$. Still, little is known about the outcome of sleep extension on nutrition in athletes.

See Table 2 for review of studies. 
Table 2: Sleep and Nutrition Research Articles

\begin{tabular}{|c|c|c|c|c|}
\hline Title and Author(s) & Participants (n) & Objective(s) & Measures Used & Conclusions \\
\hline \multicolumn{5}{|l|}{ Sleep Extension } \\
\hline $\begin{array}{l}\text { Treatment of Obesity } \\
\text { with extension of sleep } \\
\text { duration: a randomized, } \\
\text { prospective, controlled } \\
\text { trial. } \\
\text { Cizza et al. (2010) }\end{array}$ & $\begin{array}{l}\text { Study } \\
\text { participants are } \\
18-50 \text { year old } \\
\text { obese, sleep } \\
\text { deprived (avg. } \\
\text { sleep less than } \\
\quad 61 / 2 \text { hours) } \\
\text { men and pre- } \\
\text { menopausal } \\
\text { women. }\end{array}$ & $\begin{array}{l}\text { To assess the } \\
\text { feasibility of } \\
\text { increasing sleep } \\
\text { duration to a } \\
\text { healthy length } \\
\text { (approx. } 71 / 2 \\
\text { hours) and to } \\
\text { determine the } \\
\text { effect of sleep } \\
\text { extension on body } \\
\text { weight. Secondary } \\
\text { objective: to } \\
\text { examine the long- } \\
\text { term effects of } \\
\text { sleep extension on } \\
\text { endocrine (leptin } \\
\text { and ghrelin) and } \\
\text { immune (cytokine) } \\
\text { parameters; the } \\
\text { prevalence of } \\
\text { metabolic } \\
\text { syndrome, body } \\
\text { composition, PVT, } \\
\text { mood and quality } \\
\text { of life. }\end{array}$ & $\begin{array}{l}\text { Activity monitors } \\
\text { (Actiwatch and } \\
\text { Actical) for sleep, } \\
\text { energy } \\
\text { expenditure, and } \\
\text { caloric intake and } \\
\text { food recall } \\
\text { questionnaires. } \\
\text { DXA, } \\
\text { computerized } \\
\text { tomography, and } \\
\text { indirect } \\
\text { calorimetry, ESS, } \\
\text { glucose } \\
\text { intolerance tests, } \\
\text { psychological } \\
\text { assessments, } \\
\text { blood samples }\end{array}$ & $\begin{array}{l}\text { Study is currently in } \\
\text { progress }\end{array}$ \\
\hline \multicolumn{5}{|l|}{ Both } \\
\hline $\begin{array}{l}\text { Brief Communication: } \\
\text { Sleep Curtailment in } \\
\text { Healthy Young Men Is } \\
\text { Associated with } \\
\text { Decreased Leptin Levels, } \\
\text { Elevated Ghrelin Levels, } \\
\text { and Increased Hunger } \\
\text { and Appetite. } \\
\text { Spiegel et al. (2004) }\end{array}$ & $\begin{array}{l}12 \text { healthy men } \\
\text { (mean age } \pm \\
\text { SD, } 22 \pm 2 \\
\text { years) }\end{array}$ & $\begin{array}{l}\text { To determine } \\
\text { whether partial } \\
\text { sleep curtailment } \\
\quad \text { ( } 2 \text { days of sleep } \\
\text { extension and } 2 \\
\text { days of sleep } \\
\text { restriction), an } \\
\text { increasingly } \\
\text { prevalent } \\
\text { behavior, alters } \\
\text { appetite } \\
\text { regulation. }\end{array}$ & $\begin{array}{l}\text { Daytime profiles of } \\
\text { plasma leptin and } \\
\text { ghrelin levels and } \\
\text { subjective ratings } \\
\text { of hunger and } \\
\text { appetite. }\end{array}$ & $\begin{array}{l}\text { Sleep restriction was } \\
\text { associated with } \\
\text { average reductions in } \\
\text { the leptin and increases } \\
\text { in ghrelin. Sleep } \\
\text { restriction also } \\
\text { increased hunger and } \\
\text { appetite, especially for } \\
\text { calorie-dense foods } \\
\text { with high CHO content }\end{array}$ \\
\hline
\end{tabular}




\begin{tabular}{|c|c|c|c|c|}
\hline $\begin{array}{l}\text { Relationships among } \\
\text { dietary nutrients and } \\
\text { subjective sleep, } \\
\text { objective sleep, and } \\
\text { napping in women. } \\
\text { Grandner et al. (2010) }\end{array}$ & $\begin{array}{l}459 \text { post- } \\
\text { menopausal } \\
\text { women (mean } \\
\text { age } 68 \pm 7.76, \\
\text { range }=50-81 \text { ) }\end{array}$ & $\begin{array}{l}\text { To describe which } \\
\text { dietary nutrient } \\
\text { variables are } \\
\text { related to } \\
\text { subjective and } \\
\text { objective habitual } \\
\text { sleep and } \\
\text { subjective and } \\
\text { objective napping. }\end{array}$ & $\begin{array}{l}\text { Objective sleep } \\
\text { using actigraphy } \\
\text { (Actillume) and } \\
\text { subjective sleep } \\
\text { with sleep diaries. } \\
\text { Food frequency } \\
\text { questionnaires for } \\
\text { dietary nutrients. }\end{array}$ & $\begin{array}{l}\text { Actigraphic nocturnal } \\
\text { sleep duration was } \\
\text { negatively associated } \\
\text { with total fat, MUFA, } \\
\text { trans fat, saturated fat, } \\
\text { PUFA, calories, gamma- } \\
\text { tocopherol, cholesterol, } \\
\text { and alpha-tocopherol- } \\
\text { eq. } \\
\text { Subjective napping was } \\
\text { significantly related to } \\
\text { fat and meat intake. }\end{array}$ \\
\hline $\begin{array}{l}\text { The Association of Sleep } \\
\text { Duration with } \\
\text { Adolescents' Fat and } \\
\text { Carbohydrate } \\
\text { Consumption. } \\
\text { Weiss et al. (2010) }\end{array}$ & $\begin{array}{l}240 \\
\text { adolescents } \\
\text { (mean age } \\
17.7 \pm 0.4 \\
\text { years) }\end{array}$ & $\begin{array}{l}\text { To investigate the } \\
\text { relation between } \\
\text { sleep duration and } \\
\text { energy } \\
\text { consumption in an } \\
\text { adolescent cohort. }\end{array}$ & $\begin{array}{l}\text { Daily } 24 \text {-hour food } \\
\text { recall and wrist } \\
\text { actigraphy } \\
\text { (Octagonal Sleep } \\
\text { Watch). }\end{array}$ & $\begin{array}{l}\text { Subjects sleeping less } \\
\text { than } 8 \text { hours consumed } \\
\text { a higher proportion of } \\
\text { calories from fats and } \\
\text { lower proportions from } \\
\text { carbohydrates. }\end{array}$ \\
\hline $\begin{array}{l}\text { Role of Sleep Timing in } \\
\text { Caloric Intake and BMI } \\
\text { Baron et al. (2011) }\end{array}$ & $\begin{array}{l}52 \text { ( } 25 \text { females) } \\
\text { volunteers } \\
\text { (mean age } \\
31 \pm 12 \text {, range } \\
18-71 \text { ) }\end{array}$ & $\begin{array}{l}\text { To evaluate the } \\
\text { role of sleep } \\
\text { timing in dietary } \\
\text { patterns and BMI. }\end{array}$ & $\begin{array}{l}\text { Sleep logs, food } \\
\text { logs, actigraphy } \\
\text { (AW-L Actiwatch) }\end{array}$ & $\begin{array}{l}\text { Late sleepers (midpoint } \\
\text { of sleep } \geq 5: 30 A M) \\
\text { consumed more } \\
\text { calories at dinner and } \\
\text { after } 8 \mathrm{pm} \text {, had higher } \\
\text { fast food, full-calories } \\
\text { soda and lower fruit } \\
\text { and vegetable } \\
\text { consumption. }\end{array}$ \\
\hline \multicolumn{5}{|l|}{ Sleep Restriction } \\
\hline $\begin{array}{l}\text { Effects of } 72 \text { Hours of } \\
\text { Sleep Deprivation on } \\
\text { Urinary Cortisol and } \\
\text { Indices of Metabolism. } \\
\text { Kant et al. (1984) }\end{array}$ & $\begin{array}{l}\text { Six male } \\
\text { volunteers (18- } \\
21 \text { years old) }\end{array}$ & $\begin{array}{l}\text { Cortisol, urea, } \\
\text { glucose, } \\
\text { electrolytes, and } \\
\text { other compounds } \\
\text { were measured in } \\
5 \text { consecutive } 24 \mathrm{~h} \\
\text { urine collections } \\
\text { during a } 72 \text { hour } \\
\text { sleep deprivation } \\
\text { study. }\end{array}$ & $\begin{array}{l}\text { Performance } \\
\text { tasks, laboratory } \\
\text { monitoring of } \\
\text { sleep, urine } \\
\text { samples }\end{array}$ & $\begin{array}{l}\text { During sleep } \\
\text { deprivation, cortisol } \\
\text { decreased slightly, urea } \\
\text { rose, glucose decreased } \\
\text { and electrolytes } \\
\text { decreased markedly. }\end{array}$ \\
\hline $\begin{array}{l}\text { Effects of Sleep and } \\
\text { Sleep Deprivation on }\end{array}$ & $\begin{array}{c}31 \text { male } \\
\text { volunteers }\end{array}$ & $\begin{array}{l}\text { To evaluate the } \\
\text { effects of }\end{array}$ & $\begin{array}{l}\text { Blood samples, } \\
\text { sleep measured by }\end{array}$ & $\begin{array}{l}\text { IL-6 may serve to } \\
\text { decrease nocturnal IL- }\end{array}$ \\
\hline
\end{tabular}




\begin{tabular}{|c|c|c|c|c|}
\hline $\begin{array}{l}\text { Interleukin-6, Growth } \\
\text { Hormone, } \\
\text { Cortisol, and Melatonin } \\
\text { Levels in Humans. } \\
\text { Redwine et al. (2000) }\end{array}$ & $\begin{array}{l}\text { (mean }=35.8 \pm \\
10.12 \text {, range } \\
=25-65)\end{array}$ & $\begin{array}{l}\text { nocturnal sleep, } \\
\text { partial night sleep } \\
\text { deprivation, and } \\
\text { sleep stages on } \\
\text { circulating } \\
\text { concentrations of } \\
\text { interleukin-6 (IL-6) } \\
\text { in relation to the } \\
\text { secretory profiles } \\
\text { of GH, cortisol, } \\
\text { and melatonin. }\end{array}$ & $\begin{array}{l}\text { ECG } \\
\text { polysomnography }\end{array}$ & $\begin{array}{l}6, \text { having implications } \\
\text { of hurting the integrity } \\
\text { of immune system } \\
\text { functioning }\end{array}$ \\
\hline $\begin{array}{l}\text { Short Sleep Duration is } \\
\text { Associated with Reduced } \\
\text { Leptin, Elevated Ghrelin, } \\
\text { and } \\
\text { Increased Body Mass } \\
\text { Index. } \\
\text { Taheri et al. (2004) }\end{array}$ & $\begin{array}{l}1024 \\
\text { volunteers } \\
\text { from the } \\
\text { Wisconsin } \\
\text { Sleep Cohort } \\
\text { Study }\end{array}$ & $\begin{array}{l}\text { To investigate the } \\
\text { association among } \\
\text { sleep duration } \\
\text { (acute and } \\
\text { habitual), } \\
\text { metabolic } \\
\text { hormones, and } \\
\text { BMl in the } \\
\text { population-based } \\
\text { Wisconsin Sleep } \\
\text { Cohort Study. }\end{array}$ & $\begin{array}{l}\text { Polysomnography, } \\
\text { questionnaire on } \\
\text { usual sleep, } \\
\text { hormone and } \\
\text { metabolite assays, } \\
\text { sleep diaries }\end{array}$ & $\begin{array}{l}\text { In subjects sleeping less } \\
\text { than } 8 \text { hours, they } \\
\text { showed } \uparrow \text { BMI } \\
\text { proportional to } \downarrow \\
\text { sleep. Short sleep } \\
\text { associated with low } \\
\text { leptin and high ghrelin, } \\
\text { independent of BMI. }\end{array}$ \\
\hline $\begin{array}{l}\text { Short Sleep Duration is } \\
\text { Associated with Reduced } \\
\text { Leptin Levels and } \\
\text { Increased } \\
\text { Adiposity: Results from } \\
\text { the Quebec Family } \\
\text { Study. } \\
\text { Chaput et al. (2007) }\end{array}$ & $\begin{array}{c}323 \text { and } 417 \\
\text { women (ages } \\
\text { 21-64). }\end{array}$ & $\begin{array}{l}\text { To explore cross- } \\
\text { sectional } \\
\text { associations } \\
\text { between short } \\
\text { sleep duration and } \\
\text { variations in body } \\
\text { fat indices and } \\
\text { leptin levels during } \\
\text { adulthood in a } \\
\text { sample of men } \\
\text { and women } \\
\text { involved in the } \\
\text { Quebec Family } \\
\text { Study. }\end{array}$ & $\begin{array}{l}\text { Anthropometric } \\
\text { measures, plasma } \\
\text { lipid-lipoprotein } \\
\text { profile, plasma } \\
\text { leptin } \\
\text { concentrations, } \\
\text { and total sleep } \\
\text { duration }\end{array}$ & $\begin{array}{l}\text { Lower adiposity for } \\
\text { those sleeping } 7-8 \\
\text { hours compared to } 5-6 \\
\text { hours. OR for obesity } \\
\text { was } 1.38 \text { for } 9-10 \text { hours } \\
\text { and } 1.69 \text { for those } \\
\text { sleeping 5-6 hours. The } \\
\text { expected measured } \\
\text { leptin levels were } \\
\text { significantly lower than } \\
\text { predicted values for } \\
\text { short duration sleepers } \\
\text { (5-6 hours) }\end{array}$ \\
\hline
\end{tabular}




\section{Conclusion}

The purpose of this comprehensive literature review was to address the present research about the effects of sleep deprivation and extension on physical and psychological performance and nutritional behaviors in collegiate athletes. In reviewing the research, there are few studies that have investigated the effects of sleep extension on psychological and physical performance as well as nutritional behaviors in collegiate athletes. Additionally, these studies show inconsistent data. Therefore further research is needed to better understand the implications of extending sleep in athletes. 


\section{CHAPTER III}

\section{STUDY TIMELINE \& DESIGN}

\section{Timeline of SleEP iN Study}

The proposal for the research project took place in November of 2012, which consisted of committee members from nutrition, exercise physiology, and the psychology department. A meeting was held with WVU's women's track and field coach early January in order to get consent to recruit his athletes. The SleEP iN intervention study took place in March 2013 and January 2014. The recruitment process began in early March 2013 (Trial 1) of the study and lasted for one week due to spring break interference at the end of the month. A second recruitment wave (Trial 2) because of a small sample size from wave one. Trail 2 started in December 2013 and lasted a month. Baseline assessments took place mid-March of 2013 (Trial 1) and early January of 2014 (Trail 2) once participants responded to the screening survey and an email to participate in the study. The intervention of extending sleep one hour more of baseline sleep was mandated over a one week period.

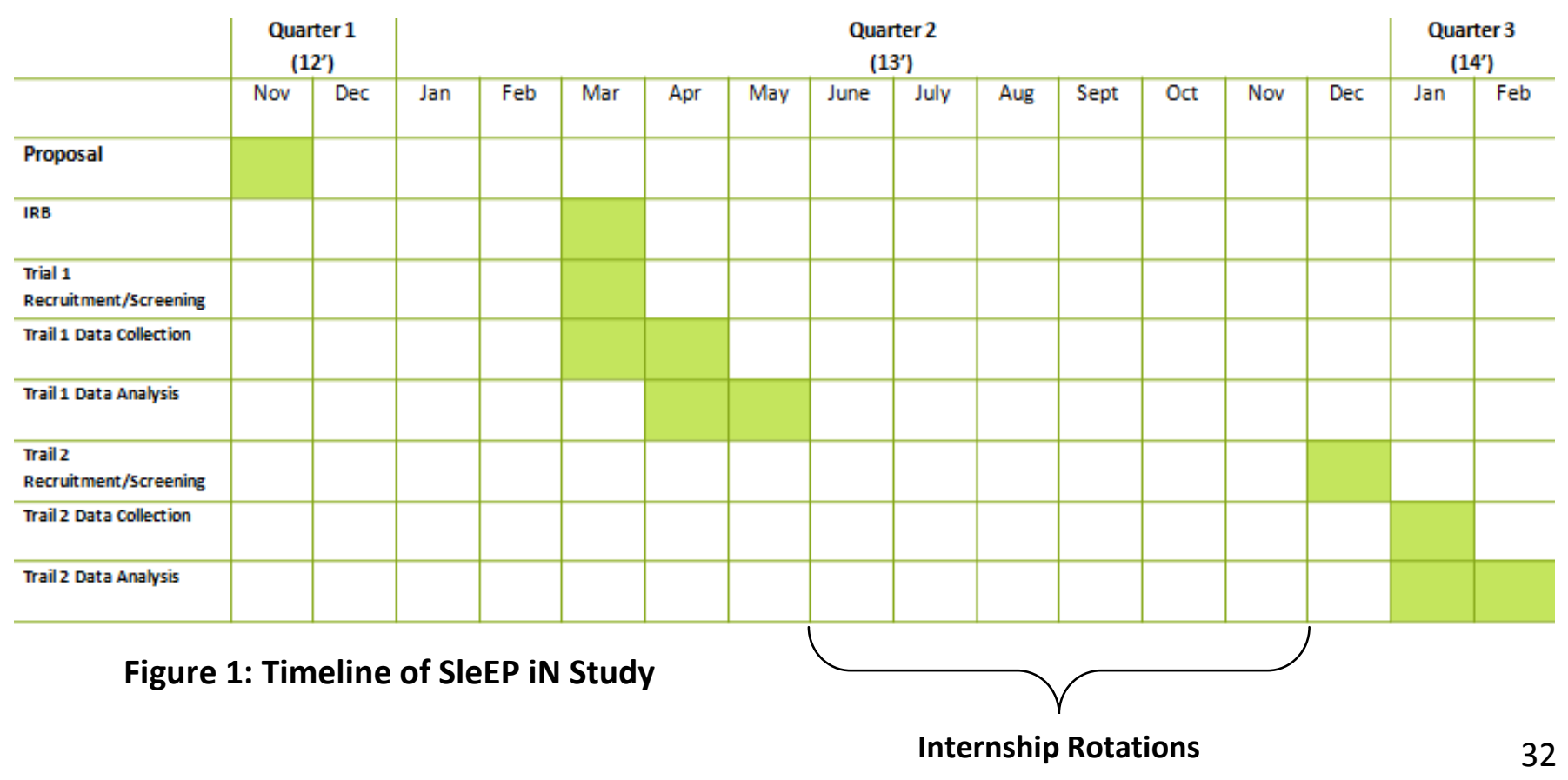




\section{SleEP iN Study Design}

Recruitment and screening of individuals was done after IRB approval and lasted for one month. Individuals were contacted if willing to participate in the study and a consent time was scheduled at the Human Performance Lab. Habitual sleep was assessed for one week then baseline data were measured (TO). Baseline data were followed by a one week sleep extension period, then post measurements were taken (T1).

\section{Intervention}

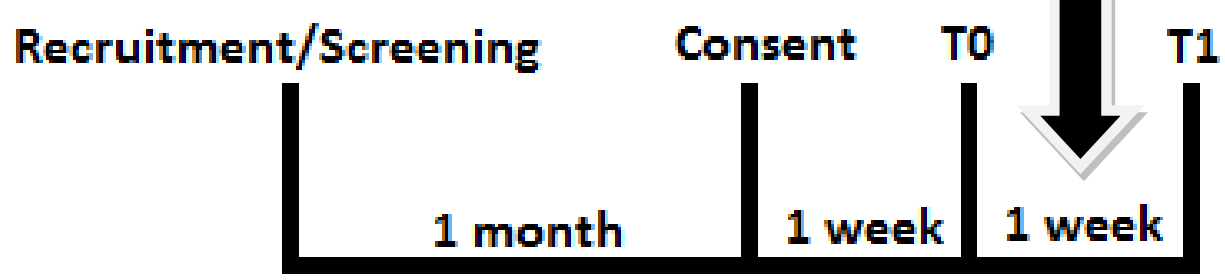

Figure 2: SleEP iN Study Design 


\section{CHAPTER IV}

\section{METHODOLOGY}

\section{IRB and Training of Research Team}

The Institutional Review Board (IRB) at WVU approved the screening survey and the SleEP iN Study in March 2013 (Appendix A). Undergraduate and graduate nutrition and exercise physiology students were recruited to train for the data collection of baseline and post-assessment for the SleEP iN Study research team. All research members were required to complete the Collaborative Institutional Training Initiative (CITI) training; attend all scheduled meetings and trainings; participate in inter-rater reliability (IRR) training to maintain consistent data measures, collection and recording at baseline and post-assessment.

\section{Recruitment}

The aim of the study was to recruit 20 WVU female track and field athletes, with emails sent targeting that group. A screening survey was sent to students' mix accounts, which were provided by the assistant WVU track and field coach. Emails were also sent to the undergraduate exercise physiology students' mix accounts provided by the secretary of the department. The reason for the inclusion of the exercise physiology department was to reach additional athletes through the department. Class announcements were also made to the classes in the departments. The inclusion criteria for the study was: 18-24 years old, female, defined as a WVU track athlete, full-time student, free from life threatening illness, pregnancy, or diet and/or activity-related medical restrictions and limited drug and alcohol intake. The screening survey was distributed to mix accounts of the students and athletes, consisting of sleep, physical activity, eating attitudes, and menstrual history questions. The survey asked the 
participant whether they agreed to be contacted by the study team and to provide contact information so they could be scheduled to be consented at the Human Performance Lab (HPL). Informed Consent Process/Health History Questionnaire

All athletes were verbally consented and signed the informed consent that was approved by WVU's IRB prior to scheduling their physical assessment. By protocol of the HPL, a review of their health history questionnaire was performed on all participants by a staff member of the HPL. After consenting was completed and their health history collected and approved, the athlete's anthropometrics including: height, weight (Bioelectrical Impedance Analysis), BMI calculated, and waist circumference were taken. An actigraph was initialized and put on the athlete's wrist and a sleep log was given in order to assess their baseline sleep. Actigraphy is an accepted method used to quantify sleep-wake activity based on subject movement ${ }^{(80)}$ in healthy young adults ${ }^{(81)}$. Actigraphy devices were worn around the wrist of the subject's dominant hand $24 \mathrm{~h} /$ day except during times were it may be immersed in water (showers or swim) and during training or competition if subject requested so (ActiGraph GT3X, Actilife 6.0 Software Pensacola, FL). Athletes were then prompted to schedule their physical assessment date.

\section{Data Collection/Assessments}

Participants of the SleEP iN Study completed a total of two assessments (baseline and one week post-assessment). All assessments were performed at the HPL at WVU's Health Sciences Campus. There were a total of four stations to complete with different physical, psychological and nutritional measures collected (Table 1). 
During assessments, anthropometrics and questionnaires were completed. Body composition, by BodPod, was only completed during the baseline assessments. Prior to assessments, the participant was instructed to remove the actigraph, where it was re-charged and re-calibrated in order to assess intervention sleep. Each anthropometric measurement was taken following standard procedures by trained research team members using calibrated equipment and recorded immediately. The Wingate Anaerobic Test (WAnT) and the BodPod protocol were completed by a staff member of the HPL to assure standard procedures were met. The WAnT is the most widely used test to evaluate anaerobic power ${ }^{(82,83)}$. Anaerobic power is an important measure for competitive athletic events which largely depend on anaerobic power ${ }^{(83,84)}$. POMS (Appendix E) was completed by the participant by hand and the PVT (Appendix E), PSS (Appendix E), Automated Self Administered (ASA) 24-diet recall and the CDC Quality of Life (Appendix E) were completed on the computer and overseen by members of the research team. After completion of all assessments, the participant was given their actigraph and sleep diary and prompted to schedule their post assessment date at least one week later, with no more than a couple days past the week deadline. Subjects were instructed to get one more hour of sleep by such methods: putting themselves to sleep earlier than usual, forming healthy sleeping habits (dark room, no distractions, etc), or waking up later than usual. Subjects received a text message of how many hours of sleep they should be aiming for from their baseline sleep data. The post-assessments consisted of the same procedures (excluding the BodPod) and the only data analyzed were from subjects who completed both pre- and posttests. The primary investigator was responsible for imputing the data into the Excel database and a research team member verified all data recorded using a two-pass data entry method. 
Table 3: Description of the Tools/Measurements

\begin{tabular}{|c|c|c|}
\hline Measure/Unit(s) & Equipment/Manufacturer & Protocol \\
\hline \multicolumn{3}{|c|}{ Stage 1: Anthropometrics } \\
\hline Height & $\begin{array}{l}\text { Model } 235 \text { Heightronic } \\
\text { Digital Stadiometer } \\
\text { Issaquah, WA }\end{array}$ & $\begin{array}{l}\text { 1. Have participants remove shoes and socks. Hair } \\
\text { ornaments to be removed if necessary. } \\
\text { 2. Instruct participants to look straight ahead and } \\
\text { maintain four points of contact (heels, buttocks, shoulder } \\
\text { blades, back of head) with the wall } \\
\text { 3. Have participant take a deep breath and stand tall } \\
\text { 4. Move the stadiometer top slide and fix it in place, } \\
\text { make sure it is firmly against participant's head } \\
\text { 5. Record height to the nearest } 0.01 \mathrm{~cm} \\
\text { 6. Repeat until measures are within } 0.2 \mathrm{~cm} \\
\text { 7. Record average to two decimal places }\end{array}$ \\
\hline $\begin{array}{l}\text { Weight }(\mathrm{kg}) \\
\text { BMI }\left(\mathrm{kg} / \mathrm{m}^{2}\right)\end{array}$ & $\begin{array}{l}\text { Model TBF- 300A Tanita } \\
\text { Electronic Scale }\end{array}$ & $\begin{array}{l}\text { 1. Zero the scale } \\
\text { 2. Have participants remove excess clothing and empty } \\
\text { bladder } \\
\text { 3. Ask participant to center both feet on the scale while } \\
\text { standing still }\end{array}$ \\
\hline Body Fat Percentage (\%) & Arlington Heights, IL & $\begin{array}{l}\text { 4. Record weight to the nearest } 0.01 \mathrm{~kg} \\
\text { 5. Repeat until within } 0.2 \mathrm{~kg} \\
\text { 6. Record average to two decimal points } \\
\text { 7. Record BMI calculated during each weight assessment }\end{array}$ \\
\hline Waist Circumference & Gulick tape & $\begin{array}{l}\text { 1. Have participant raise their shirt and lower their shorts } \\
\text { directly below the top of the iliac crests (hip bones) } \\
\text { 2. Palpate for the top of the participant's iliac crests (hip } \\
\text { bones) and place gulick tape measure accordingly } \\
\text { 3. Have participants take a deep breath and exhale; } \\
\text { measure at the end of the expiration } \\
\text { 4. Tighten the tape gently } \\
\text { 5. Repeat until two measures are within } 0.5 \mathrm{~cm} \\
\text { 6. Record average to two decimal places }\end{array}$ \\
\hline
\end{tabular}




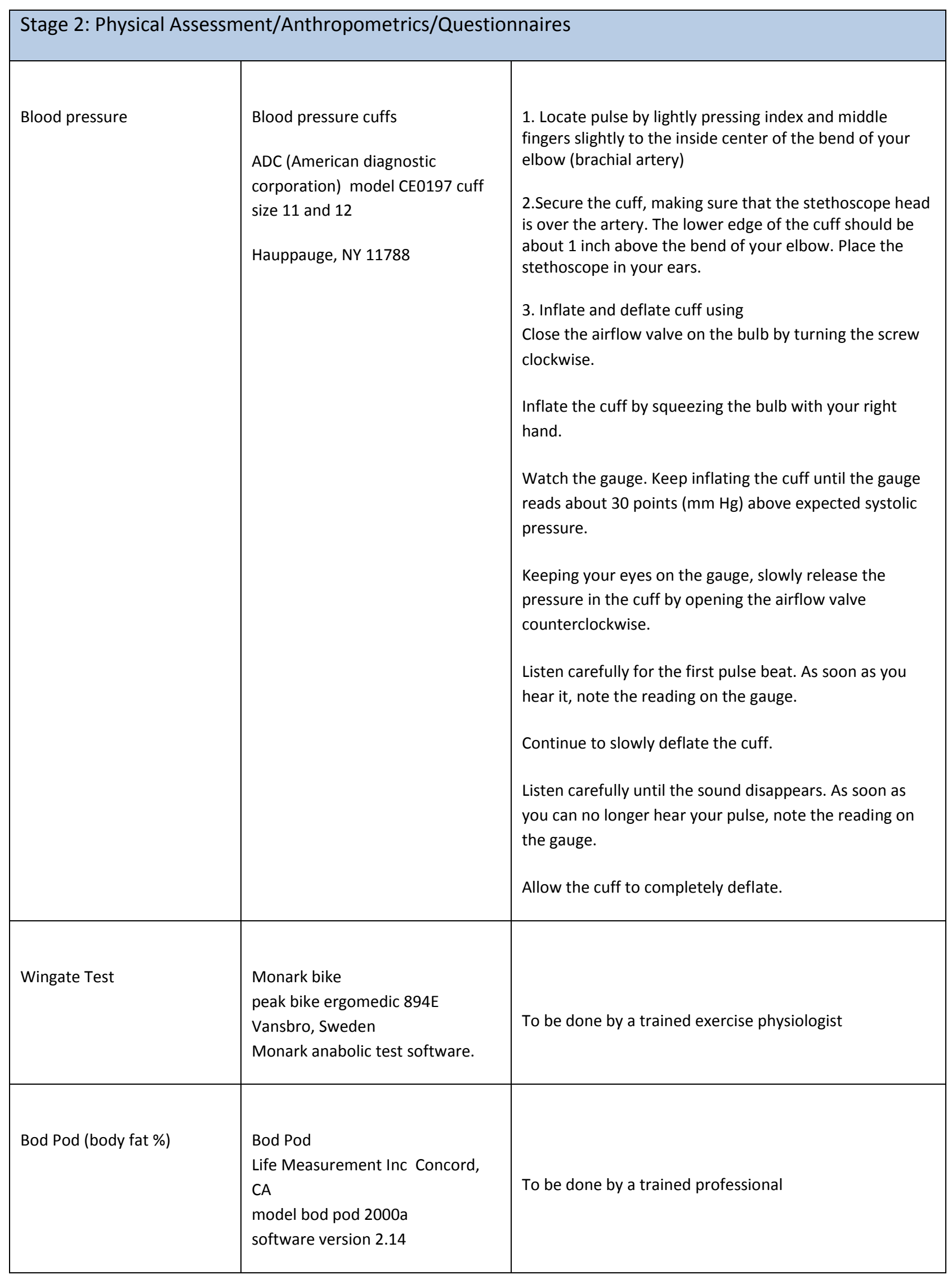




\begin{tabular}{|c|c|c|}
\hline *Reaction Test & $\begin{array}{l}\text { Tiredness Test } \\
\text { Welcome Collection } \\
183 \text { Euston Road, London }\end{array}$ & $\begin{array}{l}\text { 1. Go to } \\
\text { http://www.wellcomecollection.org/tiredness/index.html } \\
\text { 2. Instruct participant to click on "Launch Tiredness Test" }\end{array}$ \\
\hline $\begin{array}{l}\text { *Same hardware and } \\
\text { software used }\end{array}$ & & $\begin{array}{l}\text { 3. Participant will react as quickly as possible to numbers } \\
\text { that pop up on screen by clicking right side of mouse. } \\
\text { 3. Record the duration, signals missed, false starts and } \\
\text { average reaction time. }\end{array}$ \\
\hline Diet Recall & $\begin{array}{l}\text { Automated Self-Administered 24- } \\
\text { hour Dietary Recall (ASA24) } \\
\text { Westat } \\
\text { Rockville, MD }\end{array}$ & $\begin{array}{l}\text { 1. Go to https://asa24.westat.com/ } \\
\text { 2. Give participant username and password combination } \\
\text { that is already assigned on the "ASA-24 } \\
\text { Username/Password" worksheet } \\
\text { 3. Have participant fill out the entire recall, making sure } \\
\text { participant also fills out supplements. }\end{array}$ \\
\hline Moods States & $\begin{array}{l}\text { Profile of Moods Questionnaire } \\
\text { Multi-Health Systems, Inc } \\
\text { North Tonawanda, NY }\end{array}$ & $\begin{array}{l}\text { 1. Give participants a Profile of Moods questionnaire } \\
\text { 2. Have participant put their ID number on the } \\
\text { questionnaire. ID numbers can be found on the "Subject's } \\
\text { name and ID numbers" worksheet } \\
\text { 3. Have participant fill out the entire questionnaire, } \\
\text { staying around to answer any questions on a specific } \\
\text { mood. Definitions of the words can be found on "POMS } \\
\text { Definitions Worksheet" }\end{array}$ \\
\hline
\end{tabular}




\begin{tabular}{|c|c|c|}
\hline Quality of Life & $\begin{array}{l}\text { Health Related Quality of Life } \\
\text { (HRQOL) } \\
\text { Centers for Disease Control and } \\
\text { Prevention } \\
\text { Atlanta, GA }\end{array}$ & $\begin{array}{l}\text { 1. Go to } \\
\text { http://wvu.qualtrics.com/SE/?SID=SV_4OsvT2wqrG87Rel } \\
\text { 2. Have participant fill out the survey using their ID } \\
\text { numbers. This can be found on the "Subject's name and } \\
\text { ID numbers" worksheet }\end{array}$ \\
\hline Self-Perception on Stress & $\begin{array}{l}\text { Perceived Stress Scale } \\
\text { Mind Garden, Inc } \\
\text { Menlo Park, CA }\end{array}$ & $\begin{array}{l}\text { 1. Go to } \\
\text { http://wvu.qualtrics.com/SE/?SID=SV_4OsvT2 wqrG87Rel } \\
\text { 2. Have participant fill out the survey using their ID } \\
\text { numbers. This can be found on the "Subject's name and } \\
\text { ID numbers" worksheet }\end{array}$ \\
\hline \multicolumn{3}{|c|}{ Stage 3: Accelerometer Destitution } \\
\hline Actigraph & $\begin{array}{l}\text { ActiGraph GT3X } \\
\text { Actilife } 6.0 \text { Software } \\
\text { Pensacola, FL }\end{array}$ & $\begin{array}{l}\text { 1. Record the last } 4 \text { digits of the accelerometer number } \\
\text { below the barcode on the participant's data sheet } \\
\text { 2. Initialize accelerometer by entering the participant's } \\
\text { height (inches), weight (pounds), birth date and ethnicity } \\
\text { 3. Provide a throughout explanation regarding how/when } \\
\text { to wear the device } \\
\text { 4. Device should not be submerged in water (i.e. shower, } \\
\text { swimming) } \\
\text { 5. Instruct participant to wear accelerometer for } 7 \text { days }\end{array}$ \\
\hline
\end{tabular}

\section{Data Analysis/Handling}

The research conducted was a qualitative and quantitative experiment using mixed

methodology. The dependent variables were the WAnT measurements, POMS, PVT scores, and amount of calories with percent of fat and carbohydrate distribution. The independent variable was the sleep extension of one hour more from baseline. 
Statistical analysis was performed using SAS 9.3 statistical software for baseline and one week post-assessment data. Descriptive data were conducted on continuous variables (age, height, weight, body fat percent, and waist circumference) with percent and frequencies analyzed for categorical variables (position on team, menstrual status, race, and year in school). The matched paired t-test was run to determine significance between the assessments and scores from pre and post data, resulting in understanding if sleep extension had an effect on physical performance and nutritional behaviors of the female athletes. The significance level was set at an alpha of $P \leq 0.05$. Adjustment of $p$ values by Bonferroni correction was used to reduce Type I error. T-test assumptions of equal variance were tested and $95 \%$ Confidence intervals of the means were reported and also assessed for significance. Effect sizes of Cohen's $\mathrm{d}$ was calculated by $\mathrm{g}^{*}$ power and a power analysis was conducted using SAS 9.3.

\section{Power Analysis}

A power analysis was run for each research question on our outcome variables (power output, fatigue index, total calories, percent fat intake) to determine statistical significance for Trial 1 of the study. Statistical significance was not achieved (0.58-0.65) on any research question, therefore an ad hoc power analysis was conducted to examine the power needed by obtaining a larger sample size. After running the power analysis to see the appropriate sample size to lower our Type II error, five additional athletes were needed to achieve a power between 0.77 and 0.83 , leading to Trail 2 . 


\section{CHAPTER V}

\section{RESULTS}

\section{Descriptive Statistics}

\section{Subject Characteristics}

The descriptive statistics of the athletes are shown in Tables 4 and 6 . After recruiting and collecting data from 25 female track and field athletes, only 21 females were included in the results. One of the four participants dropped out of the study due to injury, two subjects had no baseline sleep data due to error of initialization of actigraphs, and one subject did not wear the actigraph at night.

Most of the athletes were Caucasian (90.5\%), followed by $4.8 \%$ African American and $4.8 \%$ other (Table 4 ). About $71.0 \%$ of the athletes were long distance athletes, $14.3 \%$ ran short distance and the remaining $14.3 \%$ participated in a field event (shot-put, discus, etc). Of the 21 female athletes, most were freshman and senior (33.3\% equally), followed by $19.1 \%$ Sophomore, 9.5\% Junior and one student (4.8\%) was a fifth year. In comparing menstrual status, 15 (71.4\%) of the athletes were classified as being eumenorrheic (periods every 28-30 days) with a small percentage being oligomenorrheic (23.8\%; periods longer than $>35$ days) or amenorrheic (2.8\%; absence of periods) (Table 4). Of those who were reported normal menstrual cycles, $47.6 \%$ were long distance runners followed by sprinters (14.3\%) and field participants (9.5\%) (Table 5). All of the participants who were considered oligomenorrheic were long distance runners (Table 5).

The average age of the participants was $20.2 \pm 1.8$ years old (Table 6$)$. Average weight of the athletes was $61.6 \pm 17.3 \mathrm{~kg}$, with an average BMI of participants being $22.8 \pm 5.1$, 
indicating normal BMI. In examining body fat percentage of the athletes by the BodPod, average body fat percentage was $19.4 \pm 8.1 \%$, with a minimum percentage of $8.7 \%$ and a maximum percentage of $40.4 \%$ (Table 6). Depending on the position in track, a healthy range of body fat percentage for female athletes may vary from $12 \%$ (i.e. sprinters and distance runners) to $22 \%$ (i.e. throwing, shot-put, and discus) ${ }^{(85)}$. However, no accepted percentage body fat standards exist for athletes.

\section{Inferential Statistics}

\section{Total Sleep Time}

According to the Pittsburgh Quality of Sleep Index conducted during screening of participants, they reported receiving 6.5-7.5 hours of sleep at night. Subject sleep logs showed a trend towards increased total time in bed by 17 minutes (0.08) (Table 8). After running a matched paired t-test, participants increased total daily sleep time from baseline to sleep extension according to objective actigraphy (Table 8, Figure 3 ). Sleep time significantly increased during the sleep extension period compared to baseline by 22 minutes $(429.3 \pm 38.4$ vs. $451.3 \pm 44.8, p=0.03$ ). The $95 \%$ confidence interval of the mean difference ( 41.35 to 2.66 ) indicated statistical significance (i.e., the confidence interval did not include 0). Cohen's d effect size suggested this difference was medium $(\mathrm{d}=0.53)$. Sleep efficiency increased following sleep extension (91.7\% vs. $92.1 \%)$, however this was not significant $(p=0.39)$.

\section{Physical Performance}

No significant differences were seen in any indices assessing physical performance using the WAnT (Table 9). Athletes showed improvement in maximal power output on the WAnT test from baseline to end of the sleep extension period $(692.9 \pm 213.16$ watts vs. $713.5 \pm 214.59$ 
watts; $p=0.07 ; d=0.10$ ). Fatigue index slightly declined when athletes slept more than habitual nightly sleep as seen by an increase in percentage from baseline (37.3\% vs. $38.3 \% ; p=0.28)$.

\section{Mental Performance}

During sleep extension compared to baseline, subjects showed no change in PVT performance (Table 10). Total Mood Disturbance Score by POMS significantly decreased following sleep extension $(p=0.01)$. The $95 \%$ confidence interval of the mean difference (1.87 to 14.22) also indicated statistical significance and the effect size suggested this difference was small $(\mathrm{d}=0.32)$. All POMS subscale scores demonstrated improvement with marked changes seen in POMS anger, tension, and depression (Table11), however none were significant after Bonferonni adjustment.

\section{Nutrient Intake}

Total energy intake and percent macronutrient distribution during baseline and sleep extension are shown in Table 10 and Figure 5. Longer sleep duration was associated with an increase in caloric intake, with an increase in percent fat (29.8 vs. $31.7 \%)$ and a decrease in percent carbohydrate (54.8 vs. 53.8\%) (Table 12). No differences were seen in percent caloric intake from protein following sleep extension (Figure 5). In addition, athletes decreased water intake after the sleep intervention (Table 13).

\section{Other Outcomes}

Number of unhealthy days (physical and mental) for baseline and sleep extension was assessed with the CDC's Quality of Life survey (Figure 6). A decrease in unhealthy days was shown from baseline to the sleep extension period. A similar trend was shown on the Cohen's 
Stress Scale with perceived stress scores (Figure 7), however there was no significant

differences seen in either.

\begin{tabular}{|l|c|c|}
\hline \multicolumn{2}{|l|}{ Table 4: Athlete Characteristics } \\
\hline & Frequency (n=21) & Percent (\%) \\
\hline Race & 19 & 90.5 \\
Caucasian & 1 & 4.8 \\
African American & 1 & 4.8 \\
Other & & \\
\hline Year in School & 7 & 33.3 \\
Freshman & 4 & 19.1 \\
Sophomore & 2 & 9.5 \\
Junior & 7 & 33.3 \\
Senior & 1 & 4.8 \\
Other & 3 & \\
\hline Position in Track & 15 & 14.3 \\
Sprinter & 3 & 71.4 \\
Long Distance & & 14.3 \\
Field & 15 & \\
\hline Menstrual Status & 5 & 71.4 \\
Eumenorrheic & 1 & 23.8 \\
Oligomenorrheic & & 4.8 \\
Amenorrheic & & \\
\hline
\end{tabular}

\begin{tabular}{|l|c|c|}
\hline \multicolumn{2}{|l|}{ Table 5: Menstrual Cycle by Position in Track } \\
\hline Sprinter & Frequency (n=21) & Percent (\%) \\
$\quad$ Eumenorrheic & 3 & 14.3 \\
Oligomenorrheic & 0 & - \\
Amenorrheic & 0 & - \\
\hline Long Distance & 10 & 47.6 \\
Eumenorrheic & 5 & 23.8 \\
Oligomenorrheic & 0 & - \\
Amenorrheic & 2 & 9.5 \\
\hline Field & 0 & - \\
Eumenorrheic & 1 & 4.8 \\
Oligomenorrheic & & \\
Amenorrheic & & \\
\hline
\end{tabular}

\begin{tabular}{|l|c|c|}
\hline Table 6: Descriptive and Anthropometrics of Athletes \\
\hline (n=21) & Mean (Standard Deviation) & Range \\
\hline Age (years) & $20.2(1.8)$ & $18-23$ \\
\hline Height (cm) & $162.4(7.1)$ & $147.8-179.0$ \\
\hline Weight (kg) & $61.6(17.3)$ & $45.8-117.7$ \\
\hline Waist (cm) & $77.7(11.3)$ & $67.5-110.0$ \\
\hline BMI (kg/m $\mathbf{m}^{2}$ & $22.8(5.1)$ & $18.2-39.1$ \\
\hline Body Fat (\%) & $19.4(8.1)$ & $8.7-40.4$ \\
\hline
\end{tabular}




\begin{tabular}{|c|c|c|c|c|c|}
\hline & Position in Track & Medications & Menstrual Status & Fat Mass (\%) & $\begin{array}{c}\text { Lean Mass } \\
\text { (\%) }\end{array}$ \\
\hline Subject 1 & Sprinter & Yaz, Multivitamin & Eumenorrheic & 27.6 & 72.4 \\
\hline Subject 2 & Long Distance & Iron, Vitamin C & Oligomenorrheic & 19.6 & 80.4 \\
\hline Subject 3 & Long Distance & Iron, Calcium, Vitamin D & Eumenorrheic & 17.1 & 82.9 \\
\hline Subject 4 & Field & $\begin{array}{l}\text { Folic acid \& B Vitamins, } \\
\text { Depo provera, Advil PRN }\end{array}$ & Amenorrheic & 25.8 & 74.2 \\
\hline Subject 5 & Long Distance & $\begin{array}{l}\text { Pulmicort, Multivitamin, } \\
\text { Vitamin C }\end{array}$ & Eumenorrheic & 8.7 & 91.3 \\
\hline Subject 6 & Long Distance & Multivitamin & Eumenorrheic & 11.5 & 88.5 \\
\hline Subject 7 & Sprinter & $\begin{array}{l}\text { Acne Medication, } \\
\text { Multivitamin }\end{array}$ & Eumenorrheic & 12.2 & 87.8 \\
\hline Subject 8 & Field & Fish Oil, Calcium & Eumenorrheic & 40.4 & 59.6 \\
\hline Subject 9 & Long Distance & Multivitamin, Vitamin D3 & Eumenorrheic & 11.8 & 88.2 \\
\hline Subject 10 & Field & $\begin{array}{l}\text { Muscle Relaxer PRN, } \\
\text { Ortho Tri-cyclen, } \\
\text { Multivitamin }\end{array}$ & Eumenorrheic & 32.7 & 67.3 \\
\hline Subject 11 & Sprinter & Lamictal & Eumenorrheic & 12.1 & 87.9 \\
\hline Subject 12 & Long Distance & Multivitamin, Vitamin D & Oligomenorrheic & 21 & 79 \\
\hline Subject 13 & Long Distance & $\begin{array}{l}\text { Multivitamin, Claritin } \\
\text { PRN, Iron }\end{array}$ & Eumenorrheic & 18.2 & 81.8 \\
\hline Subject 14 & Long Distance & None & Eumenorrheic & 14 & 86 \\
\hline Subject 15 & Long Distance & $\begin{array}{c}\text { Singulair, Prozac, } \\
\text { Loestrin, Symbicort, } \\
\text { Omeprazole, Allegra, } \\
\text { Mucinex }\end{array}$ & Eumenorrheic & 29.9 & 70.1 \\
\hline Subject 16 & Long Distance & $\begin{array}{l}\text { Calcium, Multivitamin, } \\
\text { Iron, B complex }\end{array}$ & Oligomenorrheic & 20.1 & 79.9 \\
\hline Subject 17 & Long Distance & Nasal Spray & Eumenorrheic & 19.7 & 80.3 \\
\hline Subject 18 & Long Distance & $\begin{array}{l}\text { Vimpat, Keppra, Iron, } \\
\text { Multivitamin, Omega } 3\end{array}$ & Oligomenorrheic & 11.9 & 88.1 \\
\hline Subject 19 & Long Distance & Multivitamin & Eumenorrheic & 13.2 & 86.8 \\
\hline Subject 20 & Long Distance & $\begin{array}{c}\text { Flonase, Iron, } \\
\text { Multivitamin, Vitamin C, } \\
\text { B complex }\end{array}$ & Oligomenorrheic & 22.2 & 77.8 \\
\hline Subject 21 & Long Distance & None & Eumenorrheic & 16.9 & 83.1 \\
\hline
\end{tabular}

\begin{tabular}{|c|c|c|c|c|}
\hline \multicolumn{7}{|c|}{ Table 8: Total Sleep Time per Night During Baseline and Sleep Extension } & $\mathbf{p}$ \\
\hline & Baseline & Sleep Extension & $\begin{array}{c}95 \% \text { CI Mean (95\% CI } \\
\text { SD) }\end{array}$ & 0.08 \\
\hline $\begin{array}{c}\text { Total Bed Time (min) } \\
\text { by Subject Sleep Logs }\end{array}$ & $465.6 \pm 48.1$ & $482.6 \pm 50.7$ & $\begin{array}{c}0.60 \text { to }-0.04(0.54 \text { to } \\
1.02)\end{array}$ & $0.03^{*}$ \\
\hline $\begin{array}{c}\text { Total Sleep Time } \\
\text { (min) }\end{array}$ & $429.3 \pm 38.4$ & $451.3 \pm 44.8$ & $\begin{array}{c}41.35 \text { to } 2.66(32.51 \text { to } \\
61.37)\end{array}$ & 0.39 \\
\hline $\begin{array}{c}\text { Total Sleep Efficiency } \\
\text { (\%) }\end{array}$ & $91.7 \pm 3.2$ & $92.1 \pm 2.5$ & $\begin{array}{c}1.48 \text { to }-0.61(1.76 \text { to } \\
3.31)\end{array}$ \\
\hline
\end{tabular}

*Significant after Bonferroni adjustment

Data presented as mean \pm standard deviation 


\begin{tabular}{|c|c|c|c|c|}
\hline & Baseline & Sleep Extension & 95\% CI Mean (95\% CI SD) & $\mathbf{p}$ \\
\hline $\begin{array}{l}\text { Power Output } \\
\text { (Watts) }\end{array}$ & $692.9 \pm 213.2$ & $713.5 \pm 214.6$ & $\begin{array}{c}43.27 \text { to }-2.10 \text { (38.13 to } \\
71.97)\end{array}$ & 0.07 \\
\hline Fatigue Index (\%) & $37.3 \pm 10.6$ & $38.3 \pm 8.4$ & $\begin{array}{c}4.28 \text { to }-1.29 \text { (4.69 to } \\
8.84)\end{array}$ & 0.28 \\
\hline
\end{tabular}

Data presented as mean \pm standard deviation

\begin{tabular}{|c|c|c|c|c|}
\hline \multicolumn{6}{|c|}{ Table 10: Mental Performance During Baseline and Sleep Extension } \\
\hline & Baseline & Sleep Extension & $\mathbf{9 5 \%}$ CI Mean (95\% Cl SD) & $\mathbf{p}$ \\
\hline $\begin{array}{c}\text { Total Mood } \\
\text { Disturbance Score }\end{array}$ & $20.2 \pm 24.5$ & $12.2 \pm 25.7$ & $\begin{array}{c}1.87 \text { to } 14.23(32.51 \text { to } \\
61.37)\end{array}$ & $0.01^{*}$ \\
\hline $\begin{array}{c}\text { Mean reaction time } \\
\text { (ms) }\end{array}$ & $302.7 \pm 20.2$ & $302.8 \pm 23.5$ & $\begin{array}{c}10.08 \text { to }-9.79(16.70 \text { to } \\
31.52)\end{array}$ & 0.98 \\
\hline
\end{tabular}

*Significant after Bonferroni adjustment

Data presented as mean \pm standard deviation

\begin{tabular}{|c|c|c|c|c|}
\hline Table 11: POMS Distribution Scores \\
\hline & Baseline & Sleep Extension & 95\% CI Mean (95\% CI SD) & $\mathbf{p}$ \\
\hline Vigor & $18.8 \pm 4.4$ & $19.4 \pm 4.9$ & $\begin{array}{c}2.35 \text { to }-1.11(2.91 \text { to } \\
5.49)\end{array}$ & 0.46 \\
\hline Fatigue & $8.1 \pm 6.1$ & $6.0 \pm 4.4$ & $\begin{array}{c}0.54 \text { to } 3.55(2.53 \text { to } \\
4.78)\end{array}$ & 0.01 \\
\hline Tension & $10.3 \pm 5.6$ & $8.3 \pm 5.8$ & $\begin{array}{c}0.05 \text { to } 3.86(3.21 \text { to } \\
6.05)\end{array}$ & 0.05 \\
\hline Depression & $7.1 \pm 6.9$ & $5.5 \pm 7.3$ & $\begin{array}{c}0.25 \text { to }-3.39(3.06 \text { to } \\
5.77)\end{array}$ & 0.09 \\
\hline Anger & $6.5 \pm 5.5$ & $5.7 \pm 5.7$ & $\begin{array}{c}1.28 \text { to }-2.90(3.52 \text { to } \\
6.64)\end{array}$ & 0.43 \\
\hline Confusion & $7.1 \pm 4.6$ & $6.1 \pm 4.3$ & $\begin{array}{c}0.67 \text { to }-2.77(2.89 \text { to } \\
5.45)\end{array}$ & 0.22 \\
\hline
\end{tabular}

Data presented as mean \pm standard deviation

\begin{tabular}{|c|c|c|c|c|}
\hline \multicolumn{5}{|c|}{ Table 12: Total Energy and Percent Macronutrient Distribution During Baseline and Sleep Extension } \\
\hline & Baseline & Sleep Extension & 95\% CI Mean (95\% Cl SD) & $\mathbf{p}$ \\
\hline Total energy (kcal) & $2107.0 \pm 681.8$ & $2126.3 \pm 744.7$ & $\begin{array}{c}252.2 \text { to }-213.8(391.6 \text { to } \\
739.2)\end{array}$ & 0.87 \\
\hline $\begin{array}{c}\text { Percentage from Fat } \\
\text { (\%) }\end{array}$ & $29.8 \pm 9.0$ & $31.7 \pm 7.8$ & $\begin{array}{c}5.19 \text { to }-1.39(5.53 \text { to } \\
10.44)\end{array}$ & 0.24 \\
\hline $\begin{array}{c}\text { Percentage from } \\
\text { Carbohydrate (\%) }\end{array}$ & $54.8 \pm 8.6$ & $53.8 \pm 8.7$ & $\begin{array}{c}2.70 \text { to }-4.83(6.33 \text { to } \\
11.94)\end{array}$ & 0.56 \\
\hline
\end{tabular}

Data presented as mean \pm standard deviation

\begin{tabular}{|c|c|}
\hline \multicolumn{2}{|c|}{ Table 13: Water Intake (g) Baseline \& Sleep Extension } \\
\hline Pre & 2606 \\
\hline Post & 2571 \\
\hline
\end{tabular}




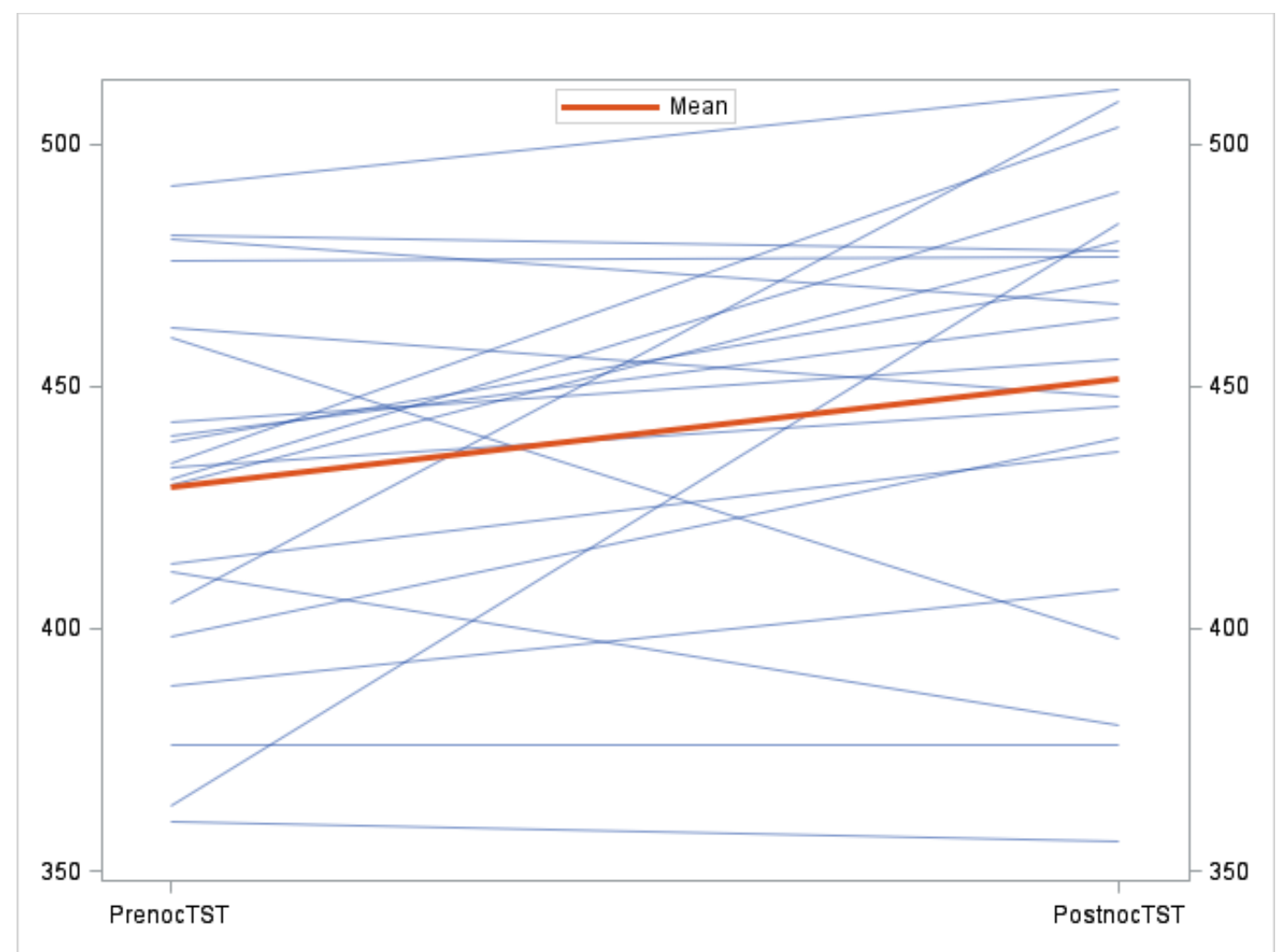

Figure 3: Subject Profiles for Pre and Post Total Time in Bed (minutes)

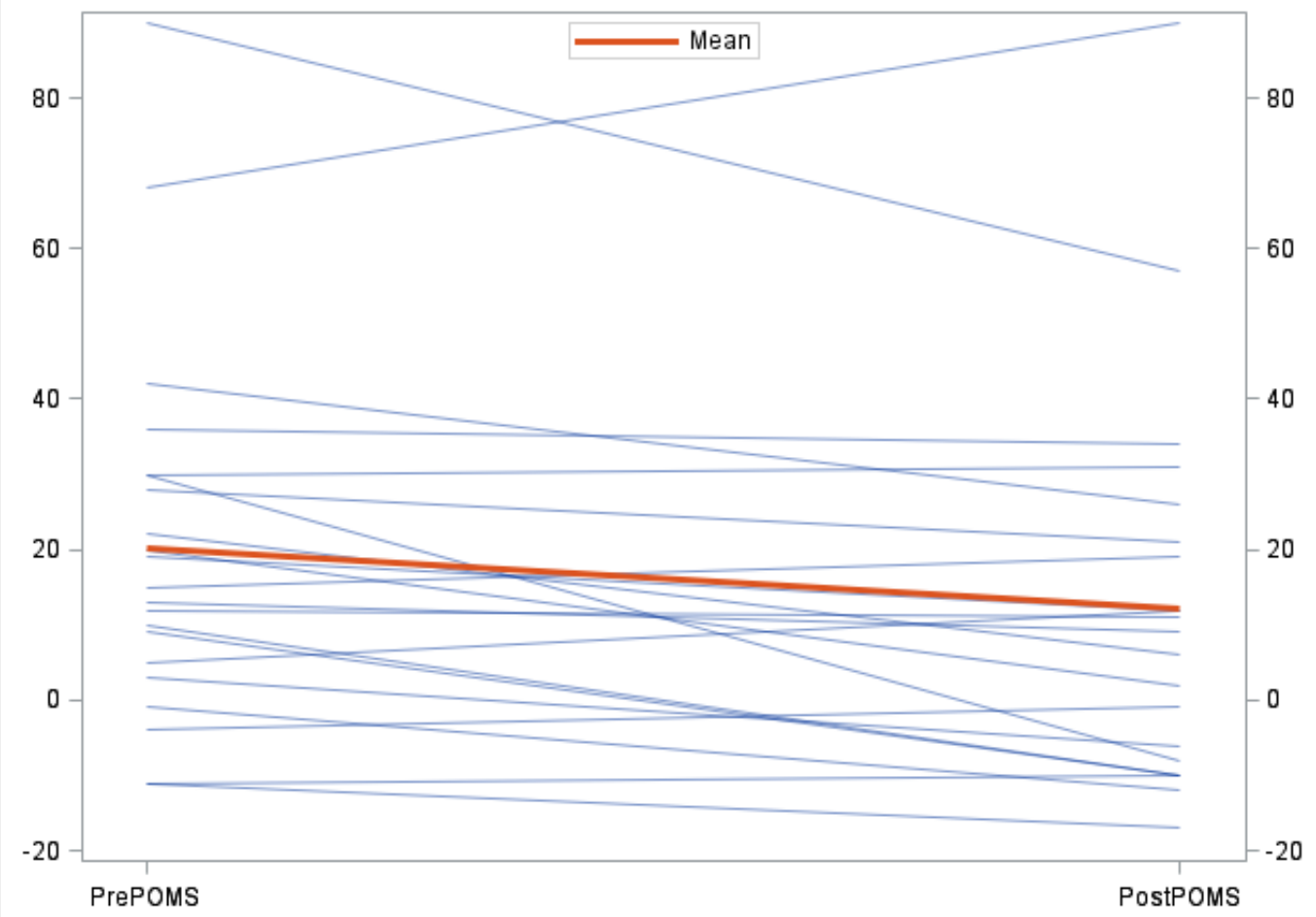

Figure 4: Subject Profiles for Pre and Post Total Mood Disturbance Scores 
Baseline Macronutrient Distribution

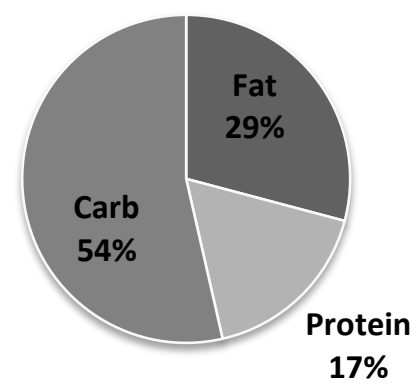

Sleep Extension Macronutrient Distribution

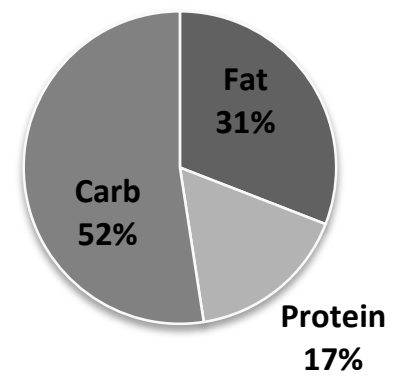

Figure 5: Macronutrient Distribution Baseline and Sleep Extension

Number of Unhealthy Days from Baseline to Sleep Extension

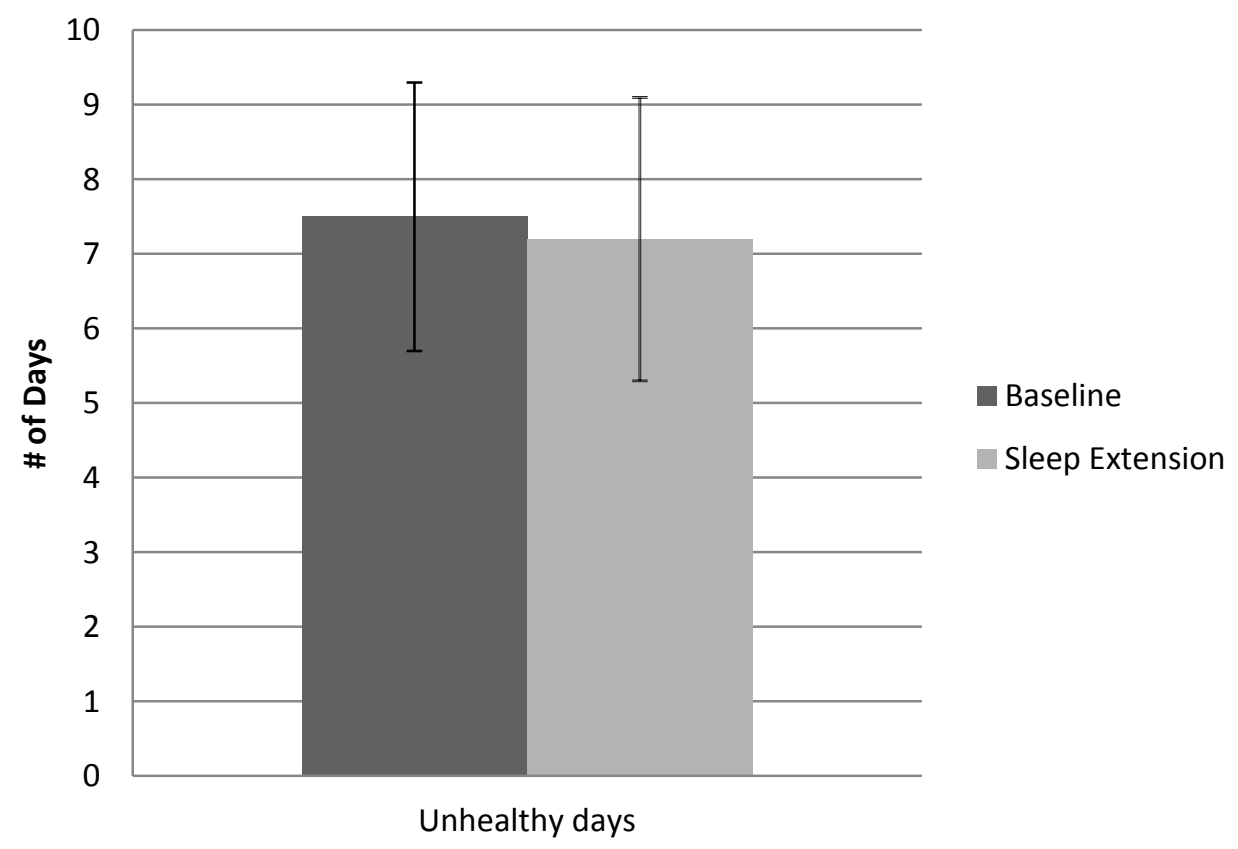

Figure 6: CDC's Quality of Life Baseline and Sleep Extension 
Perceived Stress Score from Baseline to Sleep

Extension

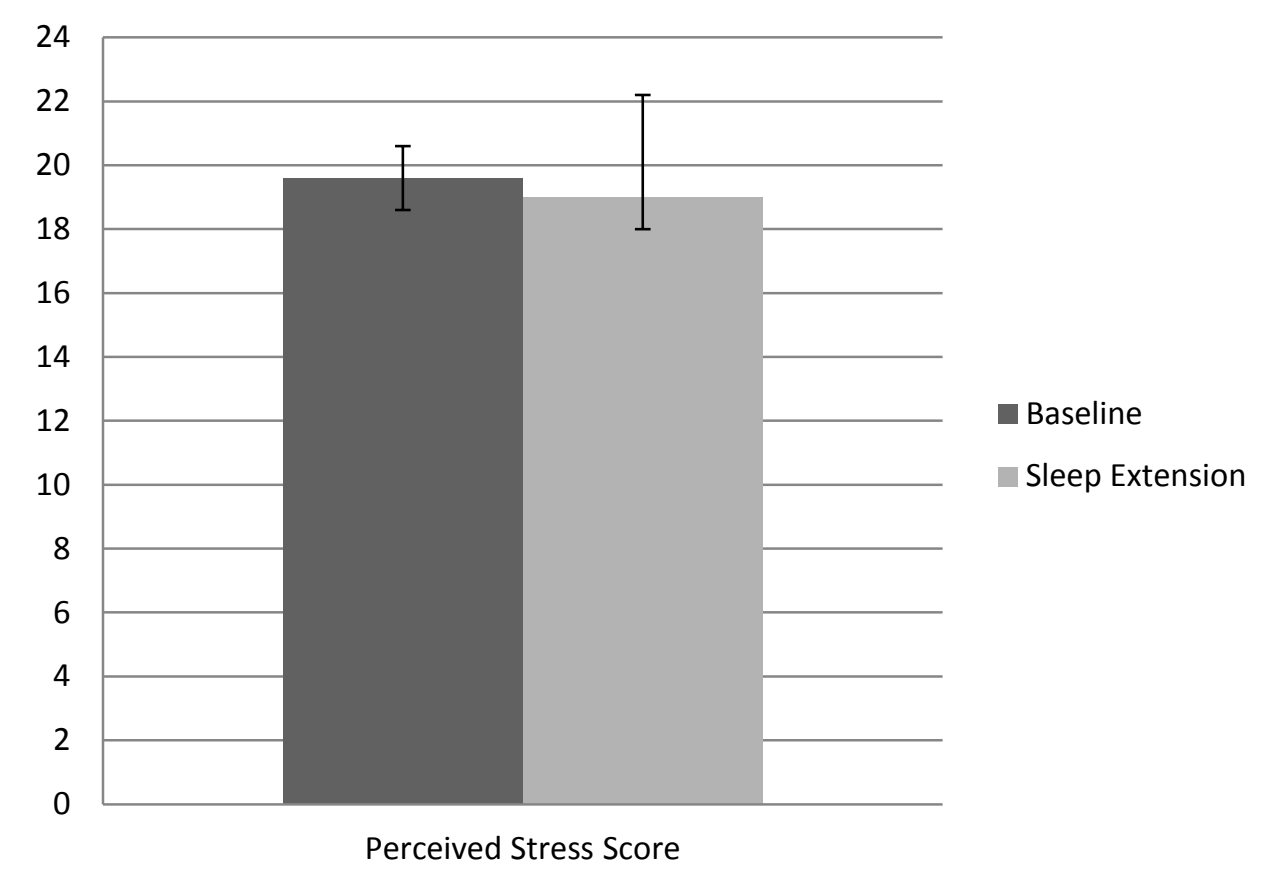

Figure 7: Cohen's Stress Baseline and Sleep Extension 


\section{CHAPTER VI}

\section{DISCUSSION}

This study was conducted under the premise that collegiate athletes carry a sizeable sleep debt from chronic sleep deprivation, due to many time commitments and busy schedules from being both a student and an athlete. In addition, studies have shown that female college students exhibit more sleep disturbances than males, with reports of more difficulty falling asleep, more frequent nocturnal awakenings, and poorer overall sleep quality than male counterparts ${ }^{(86)}$. Total nightly baseline sleep in our study $(7.16 \mathrm{~h})$ is consistent with the findings by Leeder et. al. (2012), showing highly trained athletes in a range for healthy sleep ${ }^{(20)}$. Although our athletes were within the healthy range compared to young adults who are shown

to be sleep deprived ${ }^{(87,88)}$, research has argued in favor of athletes receiving added sleep for its physiological and psychological restorative effects that occur with training and competition ${ }^{(32)}$. Nonetheless, our subjects were able to significantly increase total nightly sleep during sleep extension (7.52h), showing that sleep debt was present before extra sleep was given. Based on self reported sleep logs from baseline and sleep extension, subjects increased total time in bed by about 20 minutes, presumably spending all of that extra time sleeping since total sleep time by actigraphy increased by 22 minutes. This shows that subjects had small sleep pressure and could have slept longer periods due to unchanged sleep efficiency. Still, this is subjective data and no good sleep onset latency measurement was utilized. Furthermore, the sleep logs illustrates that subjects did not follow the sleep protocol, where many reported sleeping later than going to bed earlier, but still not getting an additional hour of sleep. However, it is still worth mentioning that no strict procedures were given to the athletes 
because we wanted them to sleep by implementing it into their schedules and not experience insomnia-like symptoms. Thus, the extra 22 minutes from baseline shows that the subjects were able to increase sleep in addition to fulfilling personal time, work and sport activities.

Participants of the WVU female varsity track and field team experienced no significant improvements or decrements in physical performance, but demonstrated significant improvements in psychological performance after sleep extension over one week. A vast majority of the literature on sleep deprivation and performance has been well documented in this population. These studies have shown that subjects who have disruptions in their normal sleep cycles by varying amounts of sleep deprivation have decreased reaction time on the $\mathrm{PVT}^{(41)}$, less positive mood ${ }^{(42)}$, decreased endurance ${ }^{(11)}$, increased resting oxygen uptake ${ }^{(12)}$, and lower sprint times ${ }^{(27)}$. In lieu of these findings, current research has looked to examine the consequence of increasing a subject's sleep on measures of performance.

Kamdar et. al. (2004) reported significant increases in MSLT scores, improvements in reaction times and POMS ratings when 15 healthy college students (male and females) slept as much as possible ${ }^{(38)}$. While this current study showed no change in reaction time from baseline to sleep extension, subjects showed significant improvements in mood, where vigor increased and fatigue, depression and tension decreased with extra sleep. These results parallel those seen in 11 National Collegiate Athletic Association (NCAA) male basketball players, who lowered POMS fatigue scores and improved POMS vigor scores ${ }^{(36)}$. The indication of these mood scores may help eliminate the assumption that athletes bear a generous amount fatigue throughout their sport's season. This study also looked at quality of life measures and stress scores and showed improvements after 20 more minutes of extra sleep. Since most of the 
females of this study train year long, it may contribute to increased stress and fatigue where treatment by sleep extension may help add to athletic performance by benefiting overall wellbeing and mental approach.

To our knowledge only two studies have been published to examine the effects of extended sleep on physical performance measures; both looking exclusively at male participants. Pierce et. al. (1993) examined endurance exercise performance and showed greater running economy $\left(\mathrm{VO}_{2}\right)$ through the first two stages of a treadmill protocol after a 60 90 minute sleep bout, while the control group of the study yielded greater economy through the remaining stages ${ }^{(37)}$. The researchers proposed that the cognitive benefits of sleep produced less anxiety in the patients for the first two stages of the protocol, with exercise duration increasing physiological arousal and limiting performance. The same proposed hypothesis may explain the differential effect of power output found in our subjects. While no significant changes were seen from baseline, subjects were able to slightly increase maximum power $(692.9 \pm 213.2$ watts vs. $713.5 \pm 214.6)$ and demonstrated decrements in maintaining fatigue index ( $37.3 \pm 10.6$ watts/sec vs. $38.3 \pm 8.4)$ as the test duration increased. Although a possible explanation could be a difference in levels of anxiety as a result of treatment, another explanation could be familiarity of the test. No pre-test was given to subjects before baseline measurements, however detailed and consistent instruction and encouragement from researchers was given for both baseline and post-assessment.

Even though our study showed no significant differences in physical performance with sleep extension, Mah et. al. (2011) found significant improvements in physical performance measures related to basketball ${ }^{(36)}$ (faster sprint time and improved shooting accuracy) with a 
minimal goal of 10 hours in bed each night for five to seven weeks. This brings to question whether the sleep extension period of this study was sufficient duration (dosage) to reveal improvements in performance and eliminate all sleep debt. Without utilizing MSLT by polysomnography, it is difficult to determine if sleep debt was eliminated. Therefore, it is likely that a longer period of sleep extension is crucial for obtaining such significant measures.

While this study's investigation focused specifically on assessing physical performance in the lab, future research may benefit from more valuable measures of performance to the sport of interest in their athletes. Although there are many advantages that exist with the WAnT test (accurate determination of load, direct assessment of maximal capacity tailored to the participant, and standard laboratory conditions) it lacks the transformation of results into field conditions and it relies on individual will and motivation from the participant. Thus, potential studies may benefit from athletic performance measures specific to the sport and during actual competition rather than practice.

As far as we are aware, this is the first study to address the impact on sleep extension on nutritional consumption. More specifically, this study looked to address the impact on increased sleep on nutrition in the athletic population, knowing that optimal performance is enhanced by proper nutrition ${ }^{(6)}$. Current knowledge on the topic of sleep and nutrition stems from research carried out over the past few decades, examining the link between the global trend in increasing obesity and sleep deprivation in children and adults ${ }^{(47)}$. Many pathways have been made known that could mediate an adverse effect of sleep loss on the risk of obesity including increases in sympathetic nervous system activity ${ }^{(52)}$, impact on hormones involved in appetite regulation $^{(56)}$, and poor eating habits ${ }^{(73,74,77)}$. Studies have shown an increase in fat 
consumption and decrease in carbohydrate consumption with sleep loss ${ }^{(73)}$. In the current study, no significant differences were seen in macronutrient distribution from baseline to sleep extension in the female track and field athletes. Since this is a novel study looking at sleep extension and dietary behavior, no research has been documented that indicates why such results may occur. Due to administration of only one 24 hour dietary recall at baseline and again at post, this could limit the chance to see significant differences after extending sleep. Although multiple-pass 24-hour diet-recall approach is considered to be a gold standard for nutrition epidemiology ${ }^{(89)}$, ideally, 24-hour recalls should be administered over multiple periods to maximize reliability. Further this is a measure of self-report rather than controlled feeding or even measured intake and output, but self-report is more realistic in the cost-effective need to do this type of research.

Although little increases in calories consumed from fat and decrease in calories consumed from carbohydrate were seen in our study population after sleep extension, the overall macronutrient distribution breakdown at baseline and sleep extension leaned toward a healthy balanced diet for endurance athletes ${ }^{(6)}$. The findings of this study may be attributed to the amount of nutritional resources available to these female athletes (access to a sports dietitian and nutrition courses offered) leading to sound nutritional practices in their diets. It is believed that many of the individuals of this study have met with or currently visit with the sports dietitian. In contrast, healthy eating behaviors have also been a result of the influence of neurotransmitters, more specifically serotonin levels ${ }^{(90)}$. It has been determined that the serotonergic system helps determine hunger, satiety, and feeding behavior where decreased levels of serotonin increase need for carbohydrates rich in sugars and refined starches in order 
to produce positive mood ${ }^{(91)}$. With increasing serotonin levels seen with exercise and adequate sleep, it is possible that our subjects decreased the amount of carbohydrate rich foods due to elevated serotonin levels with sleep extension and increased activity. Nevertheless, there is still conflicting data that shows the athletes in our study mimicking the trend towards proobesogenic (increase in fat intake) behaviors seen in subjects who were sleep deprived. While this behavior may have occurred, no biochemical data were taken (i.e. urine excretion, blood samples) and levels of cravings were not assessed to further examine why such results would occur. Thus, future studies would look to invest in such methods to further examine nutrient intake.

Our results are consistent with a study on female collegiate athletes where the majority (72.5\%) of the athletes were asymptomatic of disordered eating and engaged in healthy eating behavior $^{(66,92)}$. However, it is warranted whether these athletes were truly asymptomatic of an eating disorder. Investigators have demonstrated athletes of lean-sports (gymnasts, endurance athletes, figure skaters) are at high risk for disordered eating ${ }^{(93)}$. Although an eating attitude survey was distributed during screening to our subjects, no data were seen from the survey or food diaries of the subjects to suggest disordered-eating symptoms were prevalent.

It should also be noted that a trend was evident for a negative association between increased sleep and decreased water intake in our subjects. This is consistent with another study where the same effect was seen with post-menopausal women ${ }^{(74)}$. A possibility of the decrease in intake could be due to water being a diuretic that may disrupt sleep. Another possibility could be that increasing sleep time may leave less time for water intake. 
In spite of the findings from this study, more research is needed to examine these potential links to the extent that it exists among female athletes. Furthermore, more studies would benefit from examining whether sleep extension as a lifestyle intervention for healthy eating is only beneficial for those who are sleep deprived and show signs of unhealthy eating patterns.

\section{Limitations}

In interpreting the results of this study, several limitations must be acknowledged. One limitation being a convenience sample was used. Due to limitations in incentives for NCAA athletes, all reported measures are subject to socially desirable responding by the subjects willing to participate in the study. Several steps were taken to encourage honest responding and participation through subjects: informed of the confidential nature of their responses, no coaches or athletic department personnel present during data collection, and participant understanding there were no right or wrong answers. Also, participants were given access to individual data if requested.

In regards to study design, study length was seven days which may be considered short and it was conducted in-season on the assumption that the subjects entered the study at a high performance level after training the previous semester. This would eliminate differences in baseline and post-intervention due to training and not the treatment of sleep extension. However, the short study length may have been insufficient in order to alter sleep debt enough to show significant differences in performance and nutrition. The researchers in this study felt a one hour increase in sleep extension was adequate as the subjects entered the study at a fairly healthy sleep range (approximately 7 hours). However, greater effects on performance and 
nutrition from the additional hour of sleep may have been better suited to a population that was more sleep deprived and receiving less than seven hours of sleep at baseline.

A third limitation of this study was the enrollment of a small sample size. Although the sample was representative of the female track and field athletes at WVU, and was slightly larger than previous studies that have studied this population, future studies would benefit for a larger study population with the addition of a control group. A traditional control arm in a study on collegiate athletes in the same team may be difficult due to small team sizes. Therefore future studies desiring a control arm are likely feasible with a population outside of one athletic team.

In looking at the study's subject breakdown, most of the athletes recruited were long distance runners. Thus, another limitation of the study was the protocol used to measure physical performance (WAnt test). Although some researchers suggest that an endurance athlete with the best suited anaerboic system may establish the margin in a race ${ }^{(94)}$, it is arguable that this test is designed for anaerobically trained athletes who possess more fast twist muscle fibers. Implementation of this protocol could explain no significant differences in physical performance seen with sleep extension as most subjects were aerobically trained. Even though the researchers in the study established the protocol before knowing the breakdown of their subjects, future research would profit by assessing physical performance with measures related to physiological status (i.e. fiber type, lactate threshold, muscle enzyme profile, etc). Lastly, although a novel part of this research looked at the treatment of sleep extension on performance and nutrition in females, there is research to demonstrate the impact on certain phases of the menstrual cycle on sleep quality ${ }^{(95)}$. In this study, menstrual cycle was 
assessed in the screening and recruitment of the subject, however it was not taken into account during data collection. Future investigation is still warranted for more studies focusing on females in this field; ideally matching like menstrual cycles among female participants in a control/intervention design would help investigators to better answer their research questions. 


\section{CHAPTER VII}

\section{SUMMARY AND CONCLUSION}

The purpose of the study was to investigate the effectiveness of sleep extension on physical and psychological performance and nutritional outcomes of female college athletes. The findings from this study demonstrate that these female athletes, ages 18-24, were able to increase sleep regardless of their time-consuming schedules. Although literature suggests that increasing sleep duration in this population will enhance performance, the findings of this study show no significant differences in pre and post physical performance measures when one more hour of sleep was given. In addition, there was no significant difference in nutritional outcomes of the female athletes after the sleep extension period. As shown in other studies, sleep deprivation leads to obesogenic behaviors, not favorable for an athlete. To our knowledge, this was the first study to examine increasing sleep duration on nutritional behaviors in this population.

Collegiate athletes have full schedules, balancing class commitments, training schedules and leisure time. When it comes to achieving optimal performance, sleep should be considered just as important as training and eating right. Future research would benefit from longer sleep extension periods with previously identification of sleep deprivation.

Finally, this study was implemented on an extreme physically fit and nutritionally sound group of people. A future implication of this study may be to treat an unhealthy population (i.e. obese individuals) and investigate sleep extension on lifestyle behaviors. 


\section{REFERENCES}

1. Walters PH. Sleep, the athlete, and performance. / le sommeil, I ' athlete et la performance. Strength \& Conditioning Journal. 2002 04;24(2):17-24.

2. Coren S. Sleep thieves: An eye-opening exploration into the science and mysteries of sleep. 1996.

3. Hartmann E. The sleep book: Understanding and preventing sleep problems in people over 50. American Association of Retired Persons; 1987.

4. Pilcher JJ, Huffcutt AJ. Effects of sleep deprivation on performance: A meta-analysis. Sleep: Journal of Sleep Research \& Sleep Medicine. 1996;19(4):318-26.

5. Porter JM, Horne JA. Exercise and sleep behaviour: A questionnaire approach. Ergonomics. 1981 07;24(7):51121.

6. American Dietetic Association, Dietitians of Canada, American College of Sports Medicine, Rodriguez NR, Di Marco NM, Langley S. American college of sports medicine position stand. nutrition and athletic performance. Med Sci Sports Exerc. 2009 Mar;41(3):709-31.

7. Larkin M. Feature: Can nutrition improve athletic performance? Lancet. 2005 Dec;366 Suppl 1:S27-8.

8. Spiegel K, Tasali E, Penev P, Van Cauter E. Brief communication: Sleep curtailment in healthy young men is associated with decreased leptin levels, elevated ghrelin levels, and increased hunger and appetite. Ann Intern Med. 2004 12/07;141(11):846-50.

9. Bonnet, M., \& Arand, D. <br />How much sleep do we need? National Sleep Foundation. 2011.

10. Luckhaupt SE, Tak S, Calvert GM. The prevalence of short sleep duration by industry and occupation in the national health interview survey. Sleep. 2010 02;33(2):149-59.

11. Oliver SJ, Costa RJS, Laing SJ, Bilzon JLJ, Walsh NP. One night of sleep deprivation decreases treadmill endurance performance. Eur J Appl Physiol. 2009 09;107(2):155-61.

12. Azboy $O$, Kaygisiz Z. Effects of sleep deprivation on cardiorespiratory functions of the runners and volleyball players during rest and exercise. Acta Physiol Hung. 2009 Mar;96(1):29-36.

13. Sadeh A, Gruber R, Raviv A. The effects of sleep restriction and extension on school-age children: What a difference an hour makes. Child Dev. 2003 03;74(2):444-55.

14. Fairbanks DNF, Mickelson SA, Woodson BT. Snoring and obstructive sleep apnea. Lippincott Williams \& Wilkins; 2002.

15. Maas JB, Wherry ML, Axelrod DJ, Hogan BR, Blumin JA. Power sleep: The revolutionary program that prepares your mind for peak performance. William Morrow Paperbacks; 1998.

16. Davenne D. Sleep of athletes - problems and possible solutions. Biol Rhythm Res. 2009 02;40(1):45-52.

17. Tsai L, Li S. Sleep patterns in college students: Gender and grade differences. J Psychosom Res. 2004 02;56(2):231.

18. LIGUORI G, SCHUNA JR,JOHN, MOZUMDAR A. Semester long changes in sleep duration for college students. College Student Journal. 2011 09;45(3):481-92.

19. Reilly T. Exercise and sleep: An overview. Sports science.London: E and FN Spon. 1986:414-9.

20. Leeder J, Glaister M, Pizzoferro K, Dawson J, Pedlar C. Sleep duration and quality in elite athletes measured using wristwatch actigraphy. J Sports Sci. 2012 03/15;30(6):541-5.

21. Carskadon MA, Dement WC. Normal human sleep: An overview. Principles and practice of sleep medicine. 2000;4:13-23.

22. Reilly T, Waterhouse J, Edwards B. Jet lag and air travel: Implications for performance. Clin Sports Med. 2005;24(2):367-80.

23. Carney CE, Waters WF. Effects of a structured problem-solving procedure on pre-sleep cognitive arousal in college students with insomnia. Behavioral Sleep Medicine. 2006;4(1):13-28.

24. Reilly T, Edwards B. Altered sleep-wake cycles and physical performance in athletes. Physiol Behav. 2007 Feb 28;90(2-3):274-84.

25. Suzuki K, Miyamoto M, Miyamoto T, Sakuta H, Hirata K. The impact of sleep disturbances on neuroendocrine and autonomic functions. Nihon Rinsho. 2012 Jul;70(7):1169-76.

26. Leger D, Metlaine A, Choudat D. Insomnia and sleep disruption: Relevance for athletic performance. Clin Sports Med. 2005 Apr;24(2):269,85, viii. 
27. Skein M, Duffield R, Edge J, Short MJ, Mundel T. Intermittent-sprint performance and muscle glycogen after 30 h of sleep deprivation. Med Sci Sports Exerc. 2011 Jul;43(7):1301-11.

28. Goodman J, Radomski M, Hart L, Plyley M, Shephard RJ. Maximal aerobic exercise following prolonged sleep deprivation. / L ' exercice aerobie maximal apres une privation de sommeil. Int J Sports Med. 1989 $12 ; 10(6): 419-23$.

29. Lindsey LR. The effects of sleep deprivation on aerobic and anaerobic performance. 1995.

30. Martin BJ, Gaddis GM. Exercise after sleep deprivation. Med Sci Sports Exerc. 1981;13(4):220-3.

31. Hill DW, Borden DO, Darnaby KM, Hendricks DN. Aerobic and anaerobic contributions to exhaustive highintensity exercise after sleep deprivation. J Sports Sci. 1994 Oct;12(5):455-61.

32. Dement WC. Sleep extension: Getting as much extra sleep as possible. Clin Sports Med. 2005 Apr;24(2):251,68, viii.

33. Barbato G, Barker C, Bender C, Giesen HA. Extended sleep in humans in 14 hour nights (LD 10:14): Relationship between REM density and spontaneous awakening. Electroencephalography \& Clinical Neurophysiology. 1994 04;90(4):291-7.

34. Koslowsky M, Babkoff $\mathrm{H}$. Meta-analysis of the relationship between total sleep deprivation and performance. Chronobiol Int. 1992 Apr;9(2):132-6.

35. Engle-Friedman M, Palencar V, Riela S. Sleep and effort in adolescent athletes. J Child Health Care. 2010 Jun;14(2):131-41.

36. Mah CD, Mah KE, Kezirian EJ, Dement WC. The effects of sleep extension on the athletic performance of collegiate basketball players. Sleep. 2011 Jul 1;34(7):943-50.

37. Pierce EF, McGowan RW, Barkett E, Fry RW. The effects of an acute bout of sleep on running economy and VO2 max. J Sports Sci. 1993 Apr;11(2):109-12.

38. Kamdar BB, Kaplan KA, Kezirian EJ, Dement WC. The impact of extended sleep on daytime alertness, vigilance, and mood. Sleep Med. 2004 09;5(5):441-8.

39. Taub JM, Globus GG, Phoebus E, Drury R. Extended sleep and performance. Nature. 1971 09/10;233(5315):142-3.

40. Harrison $Y$, Horne JA. Long-term extension to sleep--are we really chronically sleep deprived? Psychophysiology. 1996 01;33(1):22-30.

41. Belenky G, Wesensten NJ, Thorne DR, Thomas ML, Sing HC, Redmond DP, et al. Patterns of performance degradation and restoration during sleep restriction and subsequent recovery: A sleep dose-response study. J Sleep Res. 2003 03;12(1):1-12.

42. Carskadon MA, Dement WC. Effects of total sleep loss on sleep tendency. Percept Mot Skills. 1979 04;48(2):495-506.

43. Roehrs T, Shore E, Papineau K, Rosenthal L, Roth T. A two-week sleep extension in sleepy normals. Sleep. 1996 09;19(7):576-82.

44. Hayashi $M$, Watanabe $M$, Hori T. The effects of a 20 min nap in the mid-afternoon on mood, performance and EEG activity. Clinical Neurophysiology. 1999 02;110(2):272-9.

45. Knutson KL, van Cauter E. Associations between sleep loss and increased risk of obesity and diabetes. Ann N Y Acad Sci. 2008 05;1129:287-304.

46. Cizza G, Skarulis M, Mignot E. A link between short sleep and obesity: Building the evidence for causation. Sleep. 2005 10;28(10):1217-20.

47. Cappuccio FP, Taggart FM, Kandala N, Currie A, Peile E, Stranges S, et al. Meta-analysis of short sleep duration and obesity in children and adults. Sleep. 2008 05;31(5):619-26.

48. Hasler G, Buysse DJ, Klaghofer R, Gamma A, Ajdacic V, Eich D, et al. The association between short sleep duration and obesity in young adults: A 13-year prospective study. Sleep. 2004 Jun 15;27(4):661-6.

49. Olds TS, Maher CA, Matricciani L. Sleep duration or bedtime? exploring the relationship between sleep habits and weight status and activity patterns. Sleep. 2011 10/01;34(10):1299-307.

50. Chaput J, Després J, Bouchard C, Tremblay A. The association between sleep duration and weight gain in adults: A 6-year prospective study from the quebec family study. Sleep: Journal of Sleep and Sleep Disorders Research. 2008 04;31(4):517-23.

51. Choi KM, Lee JS, Park HS, Baik SH, Choi DS, Kim SM. Relationship between sleep duration and the metabolic syndrome: Korean national health and nutrition survey 2001. Int J Obes. 2008 07;32(7):1091-7. 
52. Kant GJ, Genser SG, Thorne DR, Pfalser JL, Mougey EH. Effects of 72 hour sleep deprivation on urinary cortisol and indices of metabolism. Sleep. 1984;7(2):142-6.

53. Chaput J, Després J, Bouchard C, Tremblay A. Short sleep duration is associated with reduced leptin levels and increased adiposity: Results from the québec family study. Obesity (19307381). 2007 01;15(1):253-61.

54. AlDabal L, BaHammam AS. Metabolic, endocrine, and immune consequences of sleep deprivation. Open Respiratory Medicine Journal. 2011 01;5:31-43.

55. Spiegel K, Tasali E, Penev P, Van Cauter E. Brief communication: Sleep curtailment in healthy young men is associated with decreased leptin levels, elevated ghrelin levels, and increased hunger and appetite. Ann Intern Med. 2004 12/07;141(11):846,W-157.

56. Taheri S, Lin L, Austin D, Young T, Mignot E. Short sleep duration is associated with reduced leptin, elevated ghrelin, and increased body mass index. PLoS Medicine. 2004 12;1(3):210-7.

57. Redwine L, Hauger RL, Gillin JC, Irwin M. Effects of sleep and sleep deprivation on interleukin-6, growth hormone, cortisol, and melatonin levels in humans. J Clin Endocrinol Metab. 2000 10;85(10):3597-603.

58. Papanicolaou DA, Wilder RL, Manolagas SC, Chrousos GP. The pathophysiologic roles of interleukin- 6 in human disease. Ann Intern Med. 1998 01/15;128(2):127-37.

59. Chaput J, Després J, Bouchard C, Tremblay A. Short sleep duration is associated with reduced leptin levels and increased adiposity: Results from the québec family study. Obesity (19307381). 2007 01;15(1):253-61.

60. Cummings DE, Foster KE. Ghrelin-leptin tango in body-weight regulation. Gastroenterology. 2003 05;124(5):1532-5.

61. Forquer LM, Camden AE, Gabriau KM, Johnson CM. Sleep patterns of college students at a public university. Journal of American College Health. 2008 Mar;56(5):563-5.

62. Quintiliani L, Allen J, Marino M, Kelly-Weeder S, Li Y. Multiple health behavior clusters among female college students. Patient Education \& Counseling. 2010 04;79(1):134-7.

63. Morse KL, Driskell JA. Observed sex differences in fast-food consumption and nutrition self-assessments and beliefs of college students. Nutr Res. 2009 03;29(3):173-9.

64. Pyle RL, Halvorson PA, Neuman PA, Mitchell JE. The increasing prevalence of bulimia in freshman college students. Int J Eat Disord. 1986 05;5(4):631-47.

65. Orzech KM, Salafsky DB, Hamilton LA. The state of sleep among college students at a large public university. Journal of American College Health. 2011 Aug;59(7):612-9.

66. Greenleaf C, Petrie TA, Carter J, Reel JJ. Female collegiate athletes: Prevalence of eating disorders and disordered eating behaviors. Journal of American College Health. 2009 Mar;57(5):489-96.

67. White S, Reynolds-Malear J, Cordero E. Disordered eating and the use of unhealthy weight control methods in college students: 1995, 2002, and 2008. EAT DISORD. 2011 2011;19(4):323-34.

68. Economos CD, Bortz SS, Nelson ME. Nutritional practices of elite athletes. practical recommendations. Sports Medicine. 1993 12;16(6):381-99.

69. Keith RE, O'Keeffe,K.A., Alt LA, Young KL. Dietary status of trained female cyclists. J Am Diet Assoc. 1989 $11 ; 89(11): 1620-3$.

70. van EB, Saris WH, Binkhorst RA, Vos JA, Elvers JW. Nationwide survey on nutritional habits in elite athletes. part I. energy, carbohydrate, protein, and fat intake. / enquete nationale sur les habitudes alimentaires des athletes d' elite. partie I: Energie, hydrate de carbones, proteines et graisses. Int J Sports Med. 1989 05;10:3-s10.

71. COLE CR, SALVATERRA GF, DAVIS JR J,E., BORJA ME, POWELL LM, DUBBS EC, et al. Evaluation of dietary practices of national collegiate athletic association division i football players. Journal of Strength \& Conditioning Research (Allen Press Publishing Services Inc ). 2005 08;19(3):490-4.

72. Jonnalagadda SS, Rosenbloom CA, Skinner R. Dietary practices, attitudes, and physiological status of collegiate freshman football players. Journal of Strength \& Conditioning Research (Allen Press Publishing Services Inc ). 2001 11;15(4):507-13.

73. Weiss A, Xu F, Storfer-Isser A, Thomas A, levers-Landis CE, Redline S. The association of sleep duration with adolescents' fat and carbohydrate consumption. Sleep. 2010 Sep;33(9):1201-9.

74. Grandner MA, Kripke DF, Naidoo N, Langer RD. Relationships among dietary nutrients and subjective sleep, objective sleep, and napping in women. Sleep Med. 2010 02;11(2):180-4.

75. Nedeltcheva AV, Kilkus JM, Imperial J, Kasza K, Schoeller DA, Penev PD. Sleep curtailment is accompanied by increased intake of calories from snacks. Am J Clin Nutr. 2009;89(1):126-33. 
76. Schmid SM, Hallschmid M, Jauch-Chara K, Wilms B, Benedict C, Lehnert H, et al. Short-term sleep loss decreases physical activity under free-living conditions but does not increase food intake under time-deprived laboratory conditions in healthy men. Am J Clin Nutr. 2009 12;90(6):1476-82.

77. Baron KG, Reid KJ, Kern AS, Zee PC. Role of sleep timing in caloric intake and BMI. Obesity (Silver Spring). 2011 07;19(7):1374-81.

78. Nishiura C, Noguchi J, Hashimoto H. Dietary patterns only partially explain the effect of short sleep duration on the incidence of obesity. Sleep. 2010 06;33(6):753-7.

79. Cizza G, Marincola P, Mattingly M, Williams L, Mitler M, Skarulis M, et al. Treatment of obesity with extension of sleep duration: A randomized, prospective, controlled trial. Clin Trials. 2010 06;7(3):274-85.

80. Weiss AR, Johnson NL, Berger NA, Redline S. Validity of activity-based devices to estimate sleep. J Clin Sleep Med. 2010 Aug 15;6(4):336-42.

81. Cellini N, Buman MP, McDevitt EA, Ricker AA, Mednick SC. Direct comparison of two actigraphy devices with polysomnographically recorded naps in healthy young adults. Chronobiol Int. 2013;30(5):691-8.

82. Bar-Or O. The wingate anaerobic test an update on methodology, reliability and validity. Sports Medicine. 1987;4(6):381-94.

83. Bulbulian R, Jeong JW, Murphy M. Comparison of anaerobic components of the wingate and critical power tests in males and females. Med Sci Sports Exerc. 1996 Oct;28(10):1336-41.

84. Nieman DC. Exercise testing and prescription: A health-related approach. Mayfield Pub.; 1999.

85. Brzycki M. The female athlete: Train for success. Wish Publishing; 2004.

86. Buboltz Jr WC, Brown F, Soper B. Sleep habits and patterns of college students: A preliminary study. Journal of American College Health. 2001;50(3):131-5.

87. Bonnet MH, Arand DL. We are chronically sleep deprived. SLEEP-NEW YORK-. 1995;18:908-11.

88. Levine B, Roehrs T, Zorick F, Roth T. Daytime sleepiness in young adults. Sleep: Journal of Sleep Research \& Sleep Medicine. 1988.

89. Jonnalagadda SS, Mitchell DC, Smiciklas-Wright H, Meaker KB, Heel Nv, Karmally W, et al. Accuracy of energy intake data estimated by a multiplepass, 24-hour dietary recall technique. J Am Diet Assoc. 2000;100(3):30311.

90. Magalhães CP, de Freitas, Manuela Figueiroa Lyra, Nogueira MI, Campina, Renata Cristinny de Farias, Takase LF, de Souza SL, et al. Modulatory role of serotonin on feeding behavior. Nutr Neurosci. 2010;13(6):246-55.

91. Wurtman RJ, Wurtman JJ. Brain serotonin, Carbohydrate-Craving, obesity and depression. Obes Res. 1995;3(S4):477S-80S.

92. Warren BJ, Stanton AL, Blessing DL. Disordered eating patterns in competitive female athletes. Int J Eat Disord. 1990;9(5):565-9.

93. Reinking MF, Alexander LE. Prevalence of disordered-eating behaviors in undergraduate female collegiate athletes and nonathletes. J Athl Train. 2005 Mar;40(1):47-51.

94. Bulbulian R, Wilcox AR, Darabos BL. Anaerobic contribution to distance running performance of trained crosscountry athletes. Med Sci Sports Exerc. 1986 Feb;18(1):107-13.

95. Shechter A, Varin F, Boivin DB. Circadian variation of sleep during the follicular and luteal phases of the menstrual cycle. Sleep. 2010 May;33(5):647-56. 


\section{APPENDICES}

Appendix A: Institutional Review Board Approval and Consent and Information Form.........66

Appendix B: Approval Letter by WVU Track and Field Coach............................................67

Appendix C: Project Directory................................................................................68

Appendix D: Screening Questionnaire.........................................................................69

Appendix E: Questionnaires/Protocols/Assessment Tools...............................................87

Appendix F: Data Collection Form ...............................................................................99 


\section{APPENDIX A}

\section{INSTITUTIONAL REVIEW BOARD APPROVAL AND CONSENT AND INFORMATION FORM}

WVU IRB Approved Protocol H-24544 Title: SleEP iN Study: Sleeping Longer to Enhance Exercise Performance in Nutrition on March 1, 2013

The 56 page document including consent can be found in the BRAAN 2 system with the tracking number 24544. 


\section{MOUNTAINIEERS}

West Virginia University

Intercollegiate Athletics

$\mathrm{PO} \mathrm{Bo} 877$

Morgantown WV 26507-0877

To the WVU IRB Review Committee:

I have met with the "Sleep In" Research Investigators that are examining the effects of sleep extension on exercise performance and nutritional behaviors in female athletes, and I support the need for research in this area. My understanding is that there will be a one week sleep intervention study that will not affect the subjects negatively. I see this study as beneficial to the athletes and the sport, therefore the researchers of this study have my provision to go along and recruit and assess the females of WVU Track and Field. It is also my understanding that this research will be completely voluntary and that the subjects will be asked to consent to participate and can leave the study at any time. Also, the data being collected from the study will be confidential and will be kept between participants and researchers.

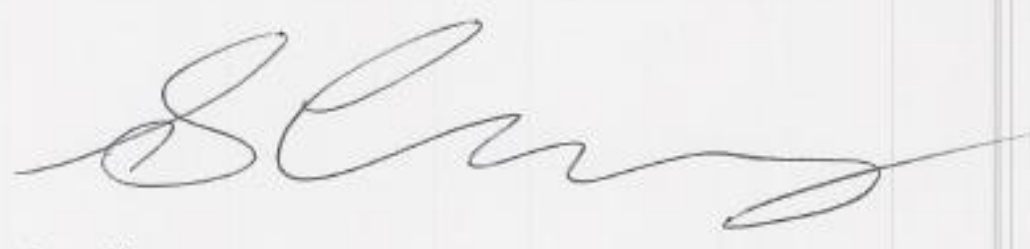

Sean Cleary

Head Coach of WVU Women's Track and Field 


\section{APPENDIX C \\ PROJECT DIRECTORY}

Melissa Olfert, Ph.D., R.D. PI

Oluremi Famodu, PI

Shannon Ackerman, Research

Assistant

Jessie Popelka, Research

Assistant

Stephanie Barton, Research

Assistant

Tiffany Mihaliak, Research

Assistant

Rachel Namey, Research

Assistant

Samantha James, Research

Assistant

Hannah Saffle, Research

Assistant

Dr. Hawley Montgomery-Downs, Committee Advisor

Dr. Randall Bryner, Committee

Advisor

Dr. Sean Cleary, Head Coach

Women's Track and Field
Melissa.olfert@mail.wvu.edu

304-293-1918

oafamodu@mix.wvu.edu

612-281-1908

snackerman@mix.wvu.edu

304-692-3559

jtpopelka@mix.wvu.edu

402-770-5441

Sbarton1@mix.wvu.edu

304-671-7469

tmihalia@mix.wvu.edu

304-677-6014

rnamey@mix.wvu.edu

304-545-6289

sjames6@mix.wvu.edu

hhoppe1@mix.wvu.edu

304-377-0300

hawley.montgomery-

downs@mail.wvu.edu

rbryner@has.wvu.edu

304-293-0441

sean.cleary@mail.wvu.edu

304-293-2101 
APPENDIX D

SCREENING QUESTIONNAIRE

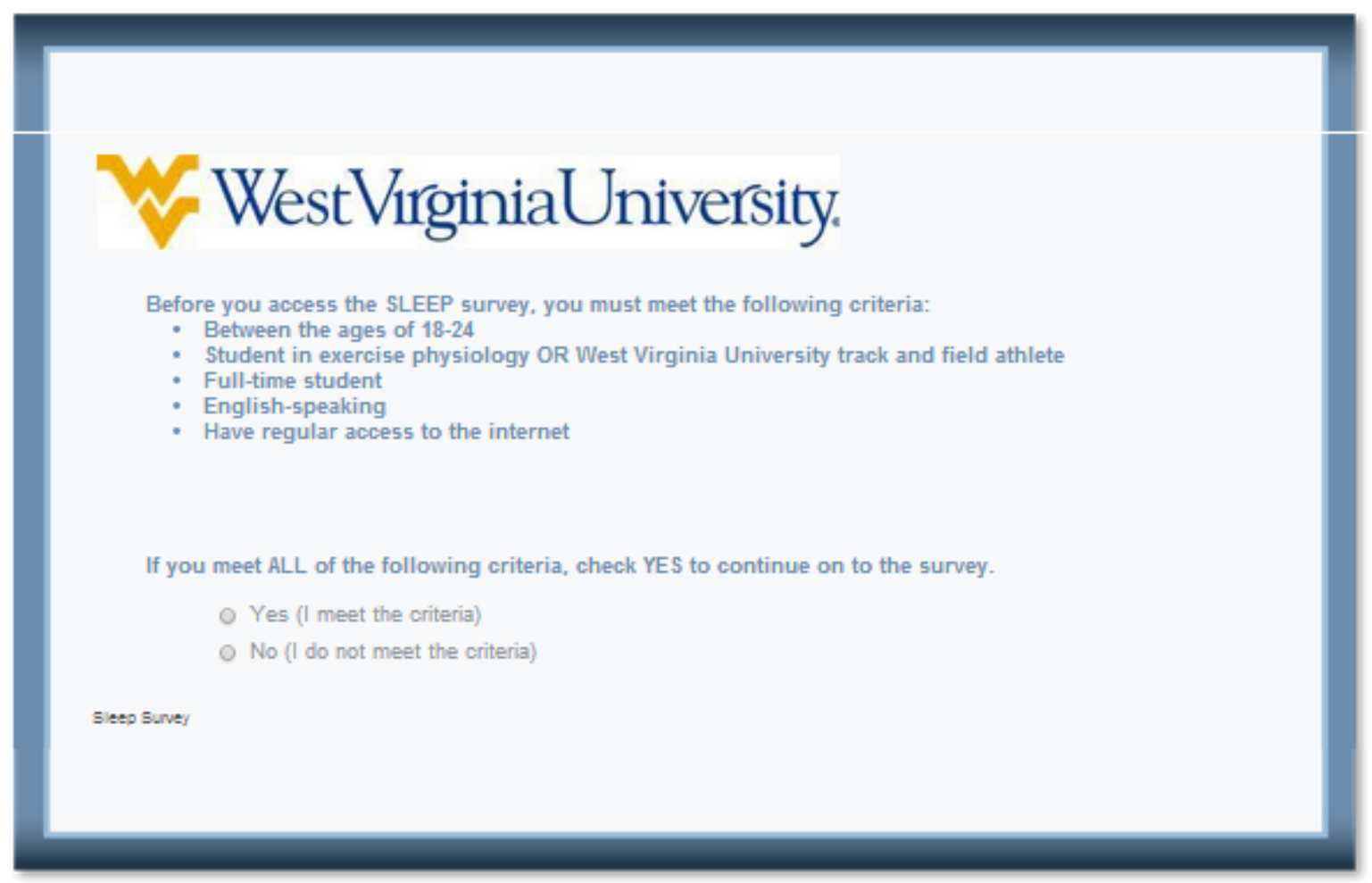

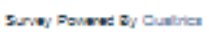




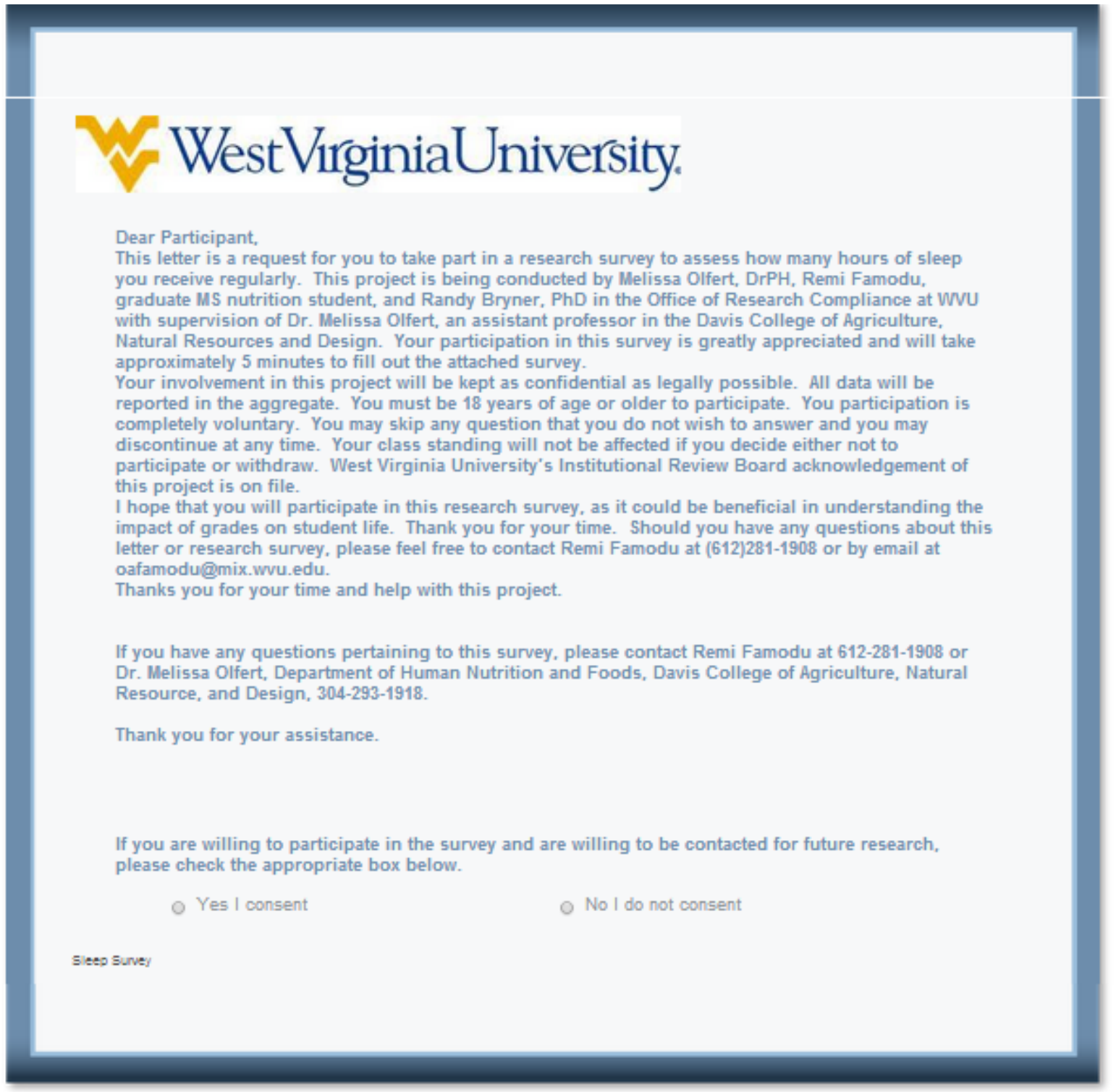

Senve Pourwe $\mathrm{D}_{j}$ Cuatica 


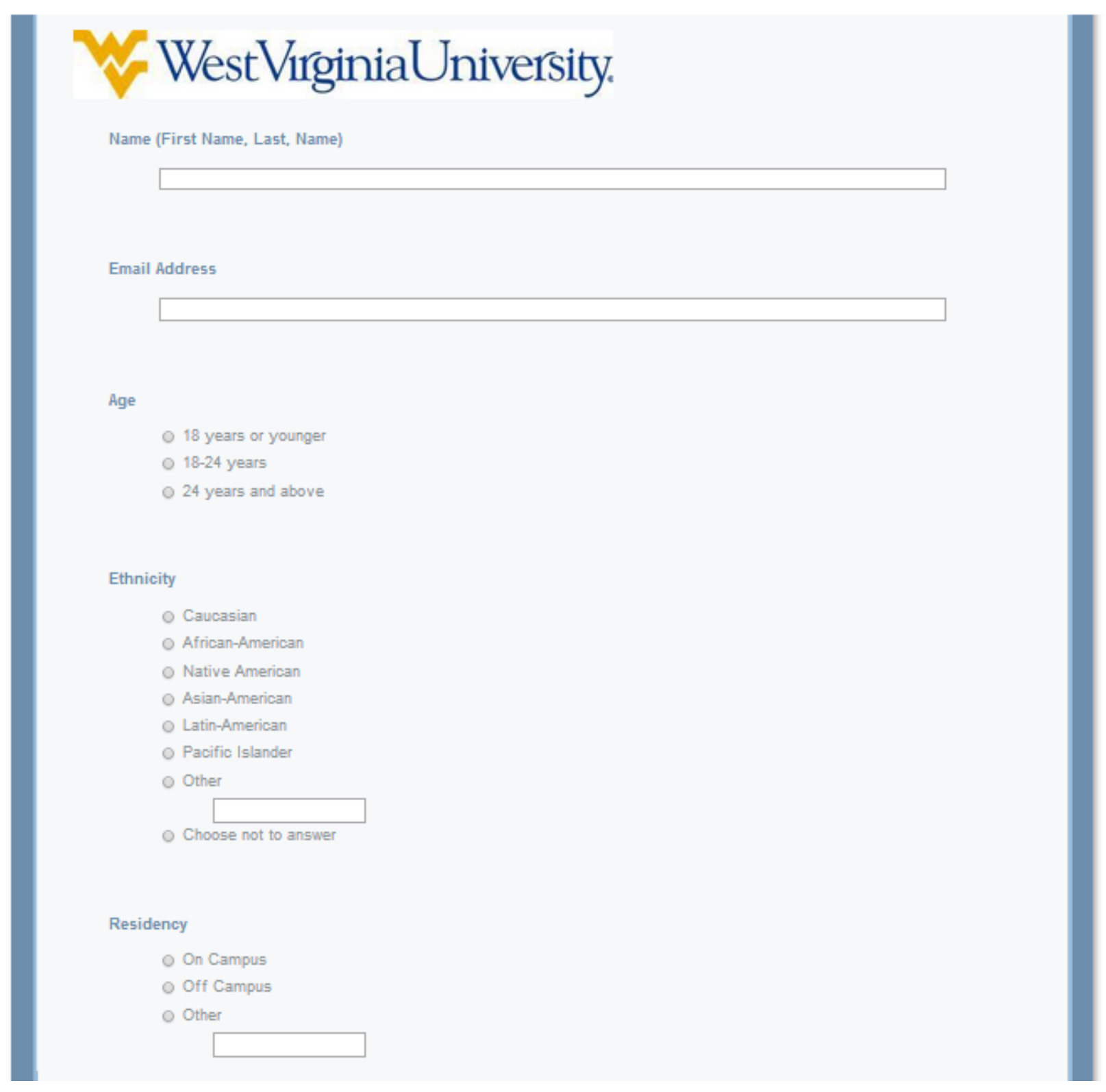


Year of Schooling

- Freshman

- Sophomore

- Junior

- Senior

- Graduate Student

o Other

Height (inches)

Weight (in lbs)

Do you smoke?

- Yes

o No

Do you use illicit drugs? ( i.e. marijuana, cocaine)

- Yes

o No

Do you consume alcohol?

- Yes

o No

Siees Survey 


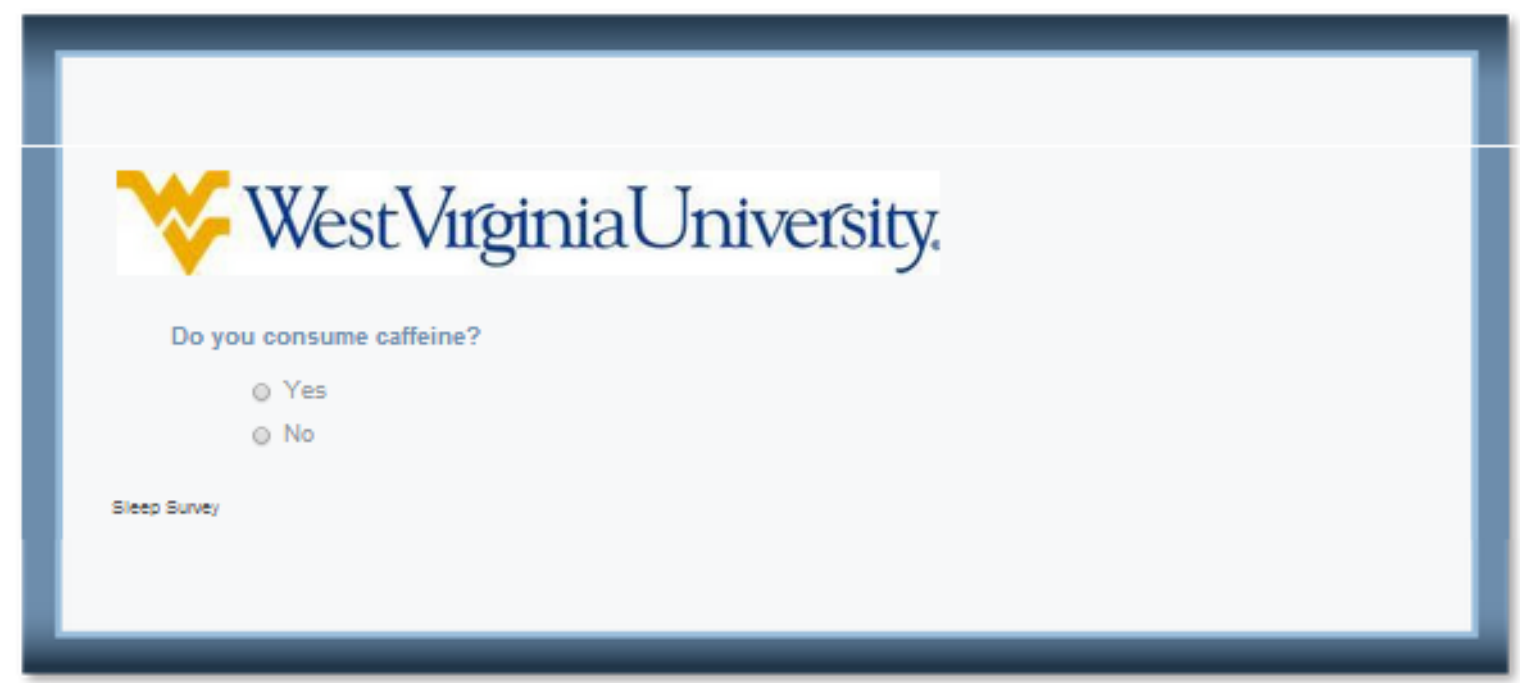

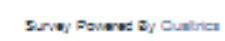


During the past month, what time have you usually gone to bed?

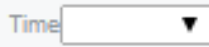

During the past month, how long (in minutes) has it usually taken you to fall asleep each night?

$$
\text { Minutes }
$$

During the past month, what time have you usually gotten up in the morning?

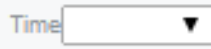

During the past month, how many hours of actual sleep did you get at night? (This may be different than the number of hours you spent in bed.)

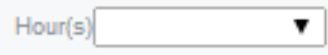

During the past month, how often have you had trouble sleeping because you...

\begin{tabular}{|c|c|c|c|c|}
\hline & $\begin{array}{l}\text { Not during the } \\
\text { past month }\end{array}$ & $\begin{array}{l}\text { Less than once } \\
\text { a week }\end{array}$ & $\begin{array}{c}\text { Once or twice a } \\
\text { week }\end{array}$ & $\begin{array}{l}\text { Three or more } \\
\text { times a week }\end{array}$ \\
\hline $\begin{array}{l}\text { Cannot get to sleep within } \\
30 \text { minutes }\end{array}$ & $\circ$ & 0 & $\circ$ & 0 \\
\hline $\begin{array}{l}\text { Wake up in the middle of } \\
\text { the night or early morning }\end{array}$ & 0 & 0 & 0 & $\circ$ \\
\hline $\begin{array}{l}\text { Have to get up to use the } \\
\text { bathroom }\end{array}$ & $\circ$ & 0 & 0 & 0 \\
\hline $\begin{array}{l}\text { Cannot breathe } \\
\text { comfortably }\end{array}$ & 0 & 0 & 0 & $\circ$ \\
\hline Cough or snore loudly & 0 & $\circ$ & 0 & $\circ$ \\
\hline Feel too cold & $\circ$ & 0 & 0 & 0 \\
\hline Feel too hot & 0 & $\circ$ & 0 & $\circ$ \\
\hline Had bad dreams & $\circ$ & $\circ$ & $\circ$ & $\circ$ \\
\hline Have pain & $\circ$ & $\circ$ & 0 & 0 \\
\hline Other (please explain) & & & & \\
\hline
\end{tabular}


During the past month, how would you rate your sleep quality overall?
Very Good
Good
Poor
- Very Poor

During the past month, how often have you taken medicine to help you sleep ( prescribed or "over the counter")?
Not during the past month
Less than once a week
Once or twice a week
Three or more times a week

During the past month, how often have you had trouble staying awake while driving. eating meals, or engaging in social activity?
Not during the past month
Less than once a week
Once or twice a week
Three or more times a week

During the past month, how much of a problem has it been for you to keep up enough enthusiasm to get things done?
Not a problem at all
Only a very slight problem
Somewhat of a problem
A very big problem

Do you have a bed partner or room mate?
No bed partner or room mate
- Partner/room mate in other room
- Partner in same room, but not same bed
Partner in same bed

Blees Surve; 


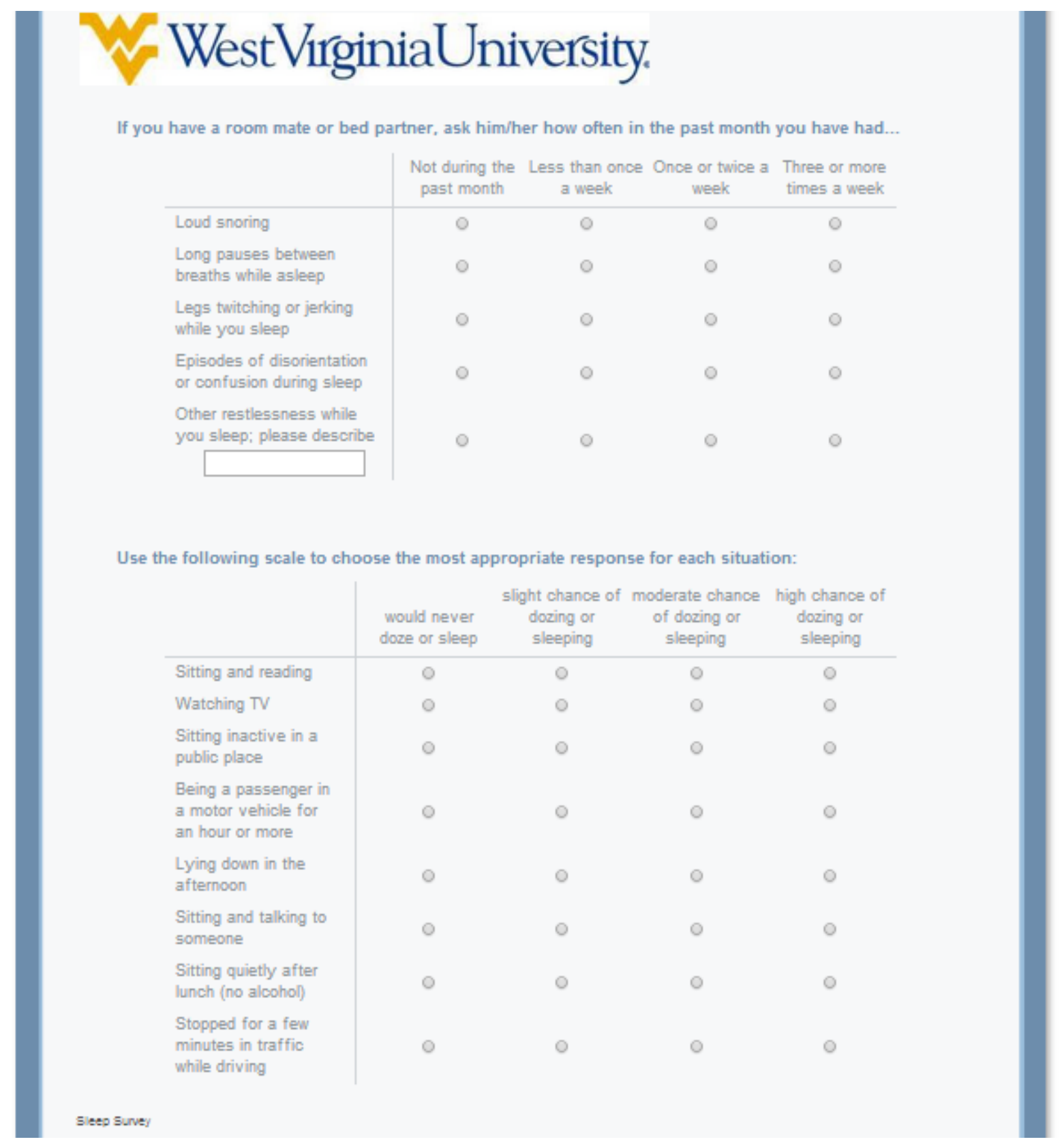




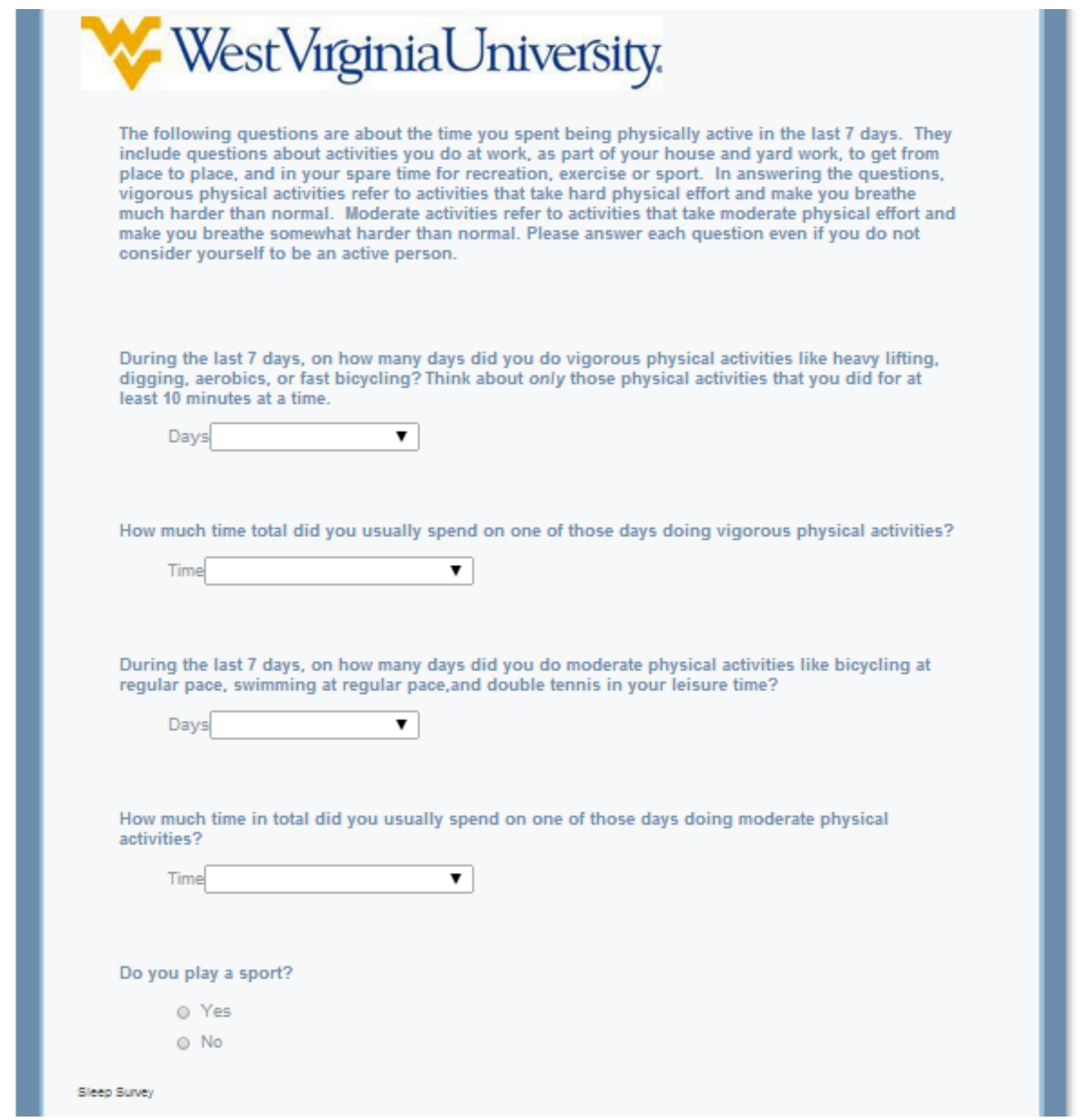




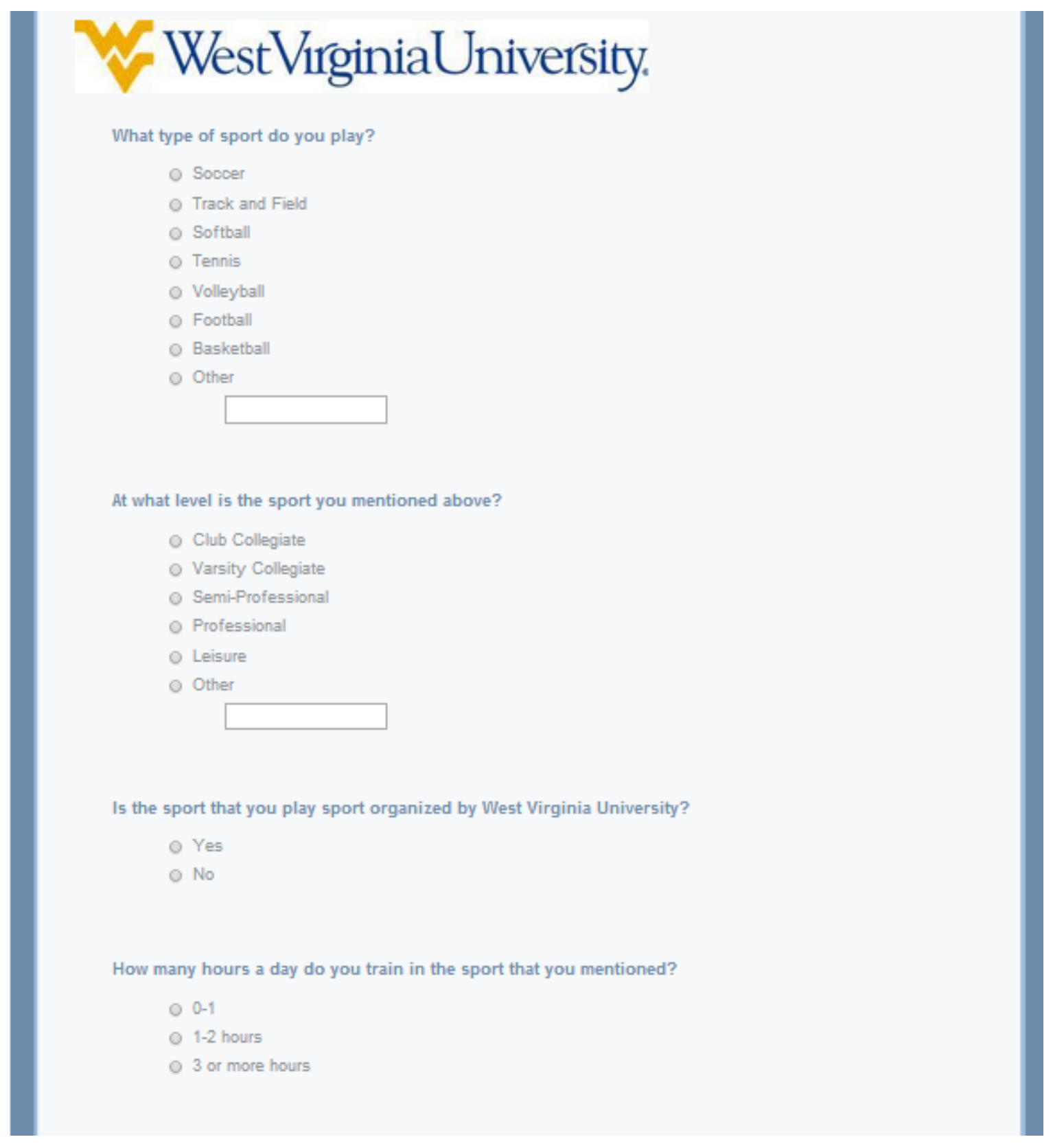


Please check the response that best reflects the extent to which you agree or disagree with each statement in relation to your own sport participation.

\begin{tabular}{|c|c|c|c|c|c|c|c|}
\hline & $\begin{array}{l}\text { Strongly } \\
\text { Disagree }\end{array}$ & Disagree & $\begin{array}{c}\text { Somewhat } \\
\text { Disagree }\end{array}$ & $\begin{array}{l}\text { Neither } \\
\text { Agree nor } \\
\text { Disagree }\end{array}$ & $\begin{array}{l}\text { Somewhat } \\
\text { Agree }\end{array}$ & Agree & $\begin{array}{l}\text { Strongly } \\
\text { Agree }\end{array}$ \\
\hline $\begin{array}{l}\text { I consider myself } \\
\text { an athlete }\end{array}$ & 0 & 0 & 0 & 0 & 0 & 0 & 0 \\
\hline $\begin{array}{l}\text { I have many goals } \\
\text { related to sport }\end{array}$ & 0 & 0 & 0 & 0 & 0 & 0 & 0 \\
\hline $\begin{array}{l}\text { Most of my friends } \\
\text { participate in sport }\end{array}$ & 0 & 0 & 0 & 0 & 0 & 0 & 0 \\
\hline $\begin{array}{l}\text { Sport is the most } \\
\text { important part of } \\
\text { my life }\end{array}$ & 0 & 0 & 0 & 0 & $\circ$ & 0 & 0 \\
\hline $\begin{array}{l}\text { I spend more time } \\
\text { thinking about sport } \\
\text { than anything else }\end{array}$ & 0 & 0 & 0 & 0 & 0 & 0 & 0 \\
\hline $\begin{array}{l}\text { Other people see } \\
\text { me as an athlete }\end{array}$ & 0 & 0 & 0 & 0 & 0 & 0 & 0 \\
\hline $\begin{array}{l}\text { I feel bad about } \\
\text { myself when I play } \\
\text { poorly in practice or } \\
\text { competition }\end{array}$ & 0 & 0 & 0 & 0 & 0 & 0 & 0 \\
\hline $\begin{array}{l}\text { Sport is the only } \\
\text { important thing in } \\
\text { my life }\end{array}$ & 0 & 0 & 0 & 0 & 0 & 0 & 0 \\
\hline $\begin{array}{l}\text { When I am } \\
\text { participating in } \\
\text { sport, I am happy }\end{array}$ & 0 & 0 & 0 & 0 & 0 & 0 & 0 \\
\hline $\begin{array}{l}\text { My family expects } \\
\text { me to participate in } \\
\text { sport }\end{array}$ & 0 & 0 & 0 & 0 & 0 & 0 & 0 \\
\hline $\begin{array}{l}\text { I feel badly when I } \\
\text { fail to meet my } \\
\text { athletic goals }\end{array}$ & 0 & 0 & 0 & 0 & $\circ$ & 0 & 0 \\
\hline $\begin{array}{l}\text { Being an athlete is } \\
\text { who I am and want } \\
\text { to make a career of } \\
\text { sport }\end{array}$ & 0 & 0 & 0 & 0 & 0 & 0 & 0 \\
\hline $\begin{array}{l}\text { It is important that } \\
\text { other people know } \\
\text { about my sport } \\
\text { involvement }\end{array}$ & 0 & 0 & 0 & 0 & 0 & 0 & 0 \\
\hline
\end{tabular}




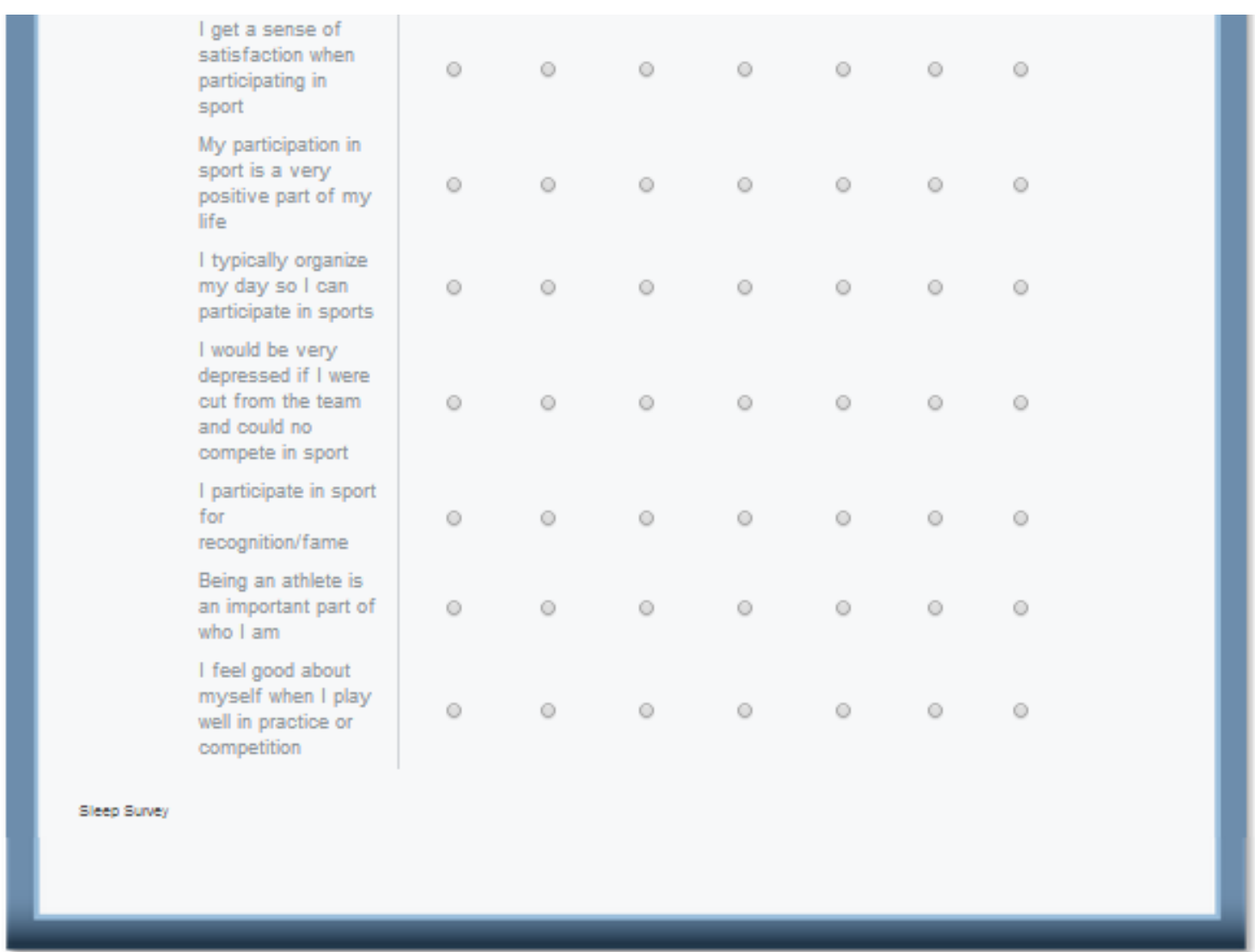

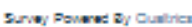




\section{W. WestVrrginiaUniversity.}

Please select the appropriate response to each statement. All answers will be kept confidential.

\begin{tabular}{|c|c|c|c|c|c|c|}
\hline & Always & Usually & Often & Sometimes & Rarely & Never \\
\hline $\begin{array}{l}\text { I am terrified about } \\
\text { being overweight }\end{array}$ & $\circ$ & 0 & 0 & 0 & 0 & 0 \\
\hline $\begin{array}{l}\text { I avoid eating when I } \\
\text { am hungry }\end{array}$ & 0 & 0 & 0 & 0 & 0 & 0 \\
\hline $\begin{array}{l}\text { I find myself } \\
\text { preoccupied with food }\end{array}$ & 0 & 0 & 0 & 0 & 0 & 0 \\
\hline $\begin{array}{l}\text { I have gone on eating } \\
\text { binges where I feel } \\
\text { that I may not be } \\
\text { able to stop }\end{array}$ & 0 & 0 & 0 & $\circ$ & 0 & 0 \\
\hline $\begin{array}{l}\text { I cut my food into } \\
\text { small pieces }\end{array}$ & 0 & 0 & 0 & 0 & 0 & 0 \\
\hline $\begin{array}{l}\text { I am aware of the } \\
\text { calorie content of } \\
\text { foods that I eat }\end{array}$ & 0 & 0 & 0 & 0 & 0 & 0 \\
\hline \multirow{2}{*}{$\begin{array}{l}\text { I particularly avoid } \\
\text { food with a high } \\
\text { carbohydrate content } \\
\text { (i.e. bread, rice, } \\
\text { potatoes) }\end{array}$} & 0 & 0 & 0 & 0 & 0 & 0 \\
\hline & Ahways & Usually & Often & Sometimes & Rarely & Never \\
\hline $\begin{array}{l}\text { I feel that others } \\
\text { would prefer I eat } \\
\text { more }\end{array}$ & 0 & 0 & 0 & 0 & $\circ$ & $\circ$ \\
\hline $\begin{array}{l}\text { I vomit after I have } \\
\text { eaten }\end{array}$ & 0 & 0 & 0 & 0 & $\circ$ & 0 \\
\hline $\begin{array}{l}\text { I feel extremely } \\
\text { guilty after eating }\end{array}$ & $\circ$ & 0 & 0 & 0 & 0 & 0 \\
\hline $\begin{array}{l}\text { I am preoccupied with } \\
\text { a desire to be thinner }\end{array}$ & 0 & 0 & 0 & 0 & $\circ$ & 0 \\
\hline $\begin{array}{l}\text { I think about burning } \\
\text { calories when I } \\
\text { exercise }\end{array}$ & 0 & $\circ$ & 0 & $\circ$ & $\circ$ & 0 \\
\hline $\begin{array}{l}\text { Other people think } \\
\text { that I am too thin }\end{array}$ & $\circ$ & 0 & 0 & 0 & 0 & 0 \\
\hline $\begin{array}{l}\text { I am preoccupied with } \\
\text { the though of having } \\
\text { fat on my body }\end{array}$ & 0 & 0 & 0 & 0 & 0 & 0 \\
\hline
\end{tabular}




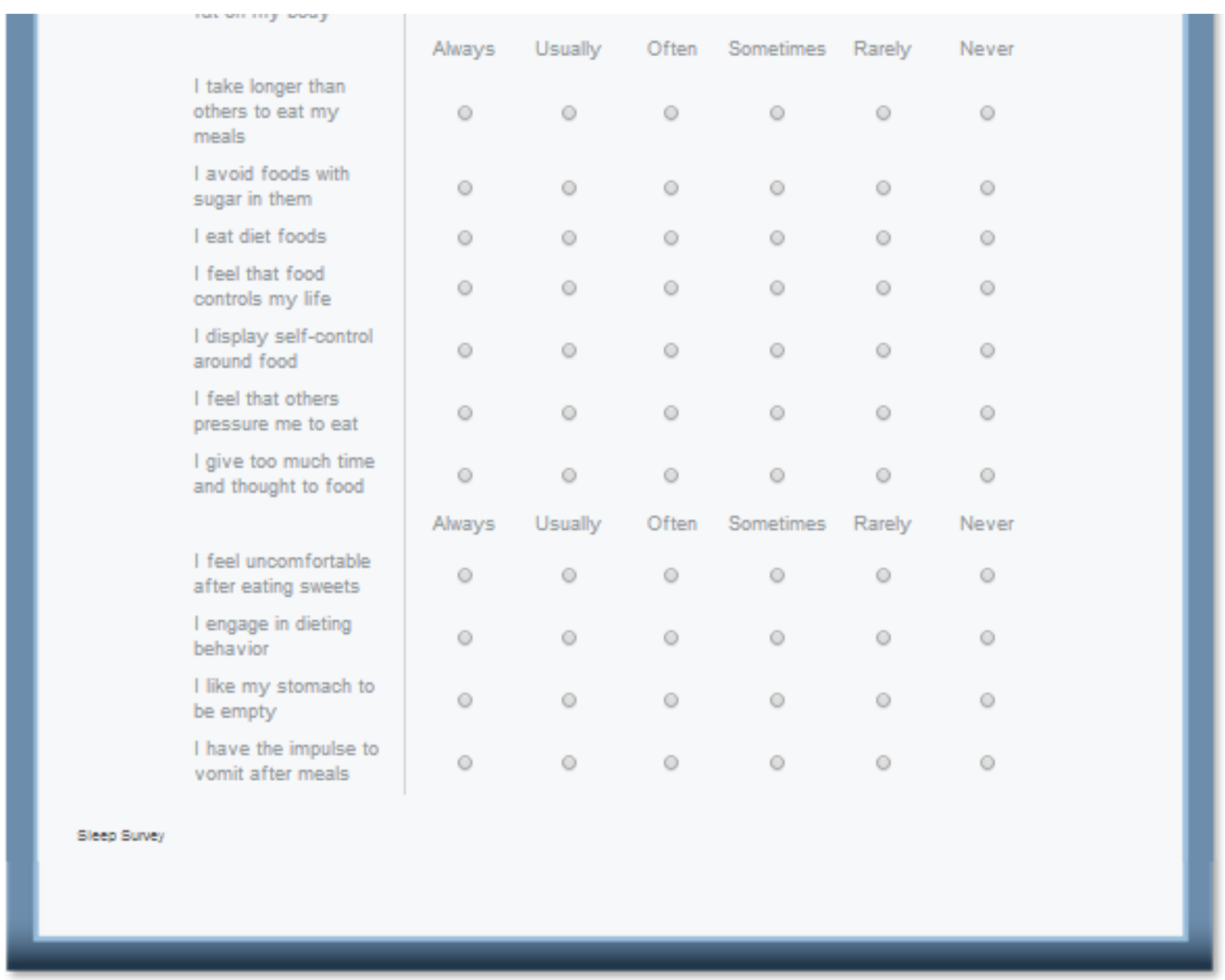

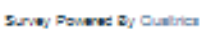




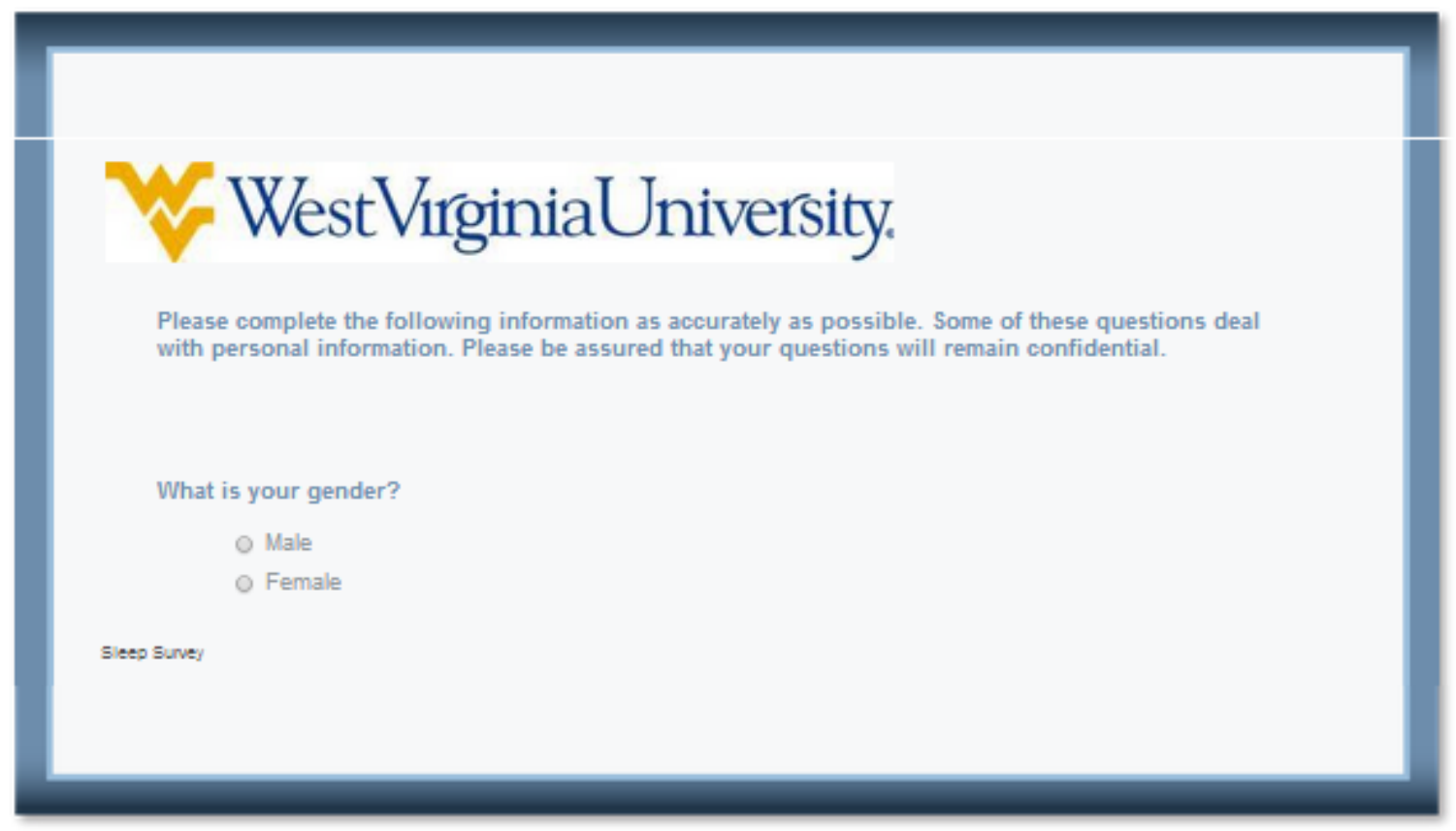




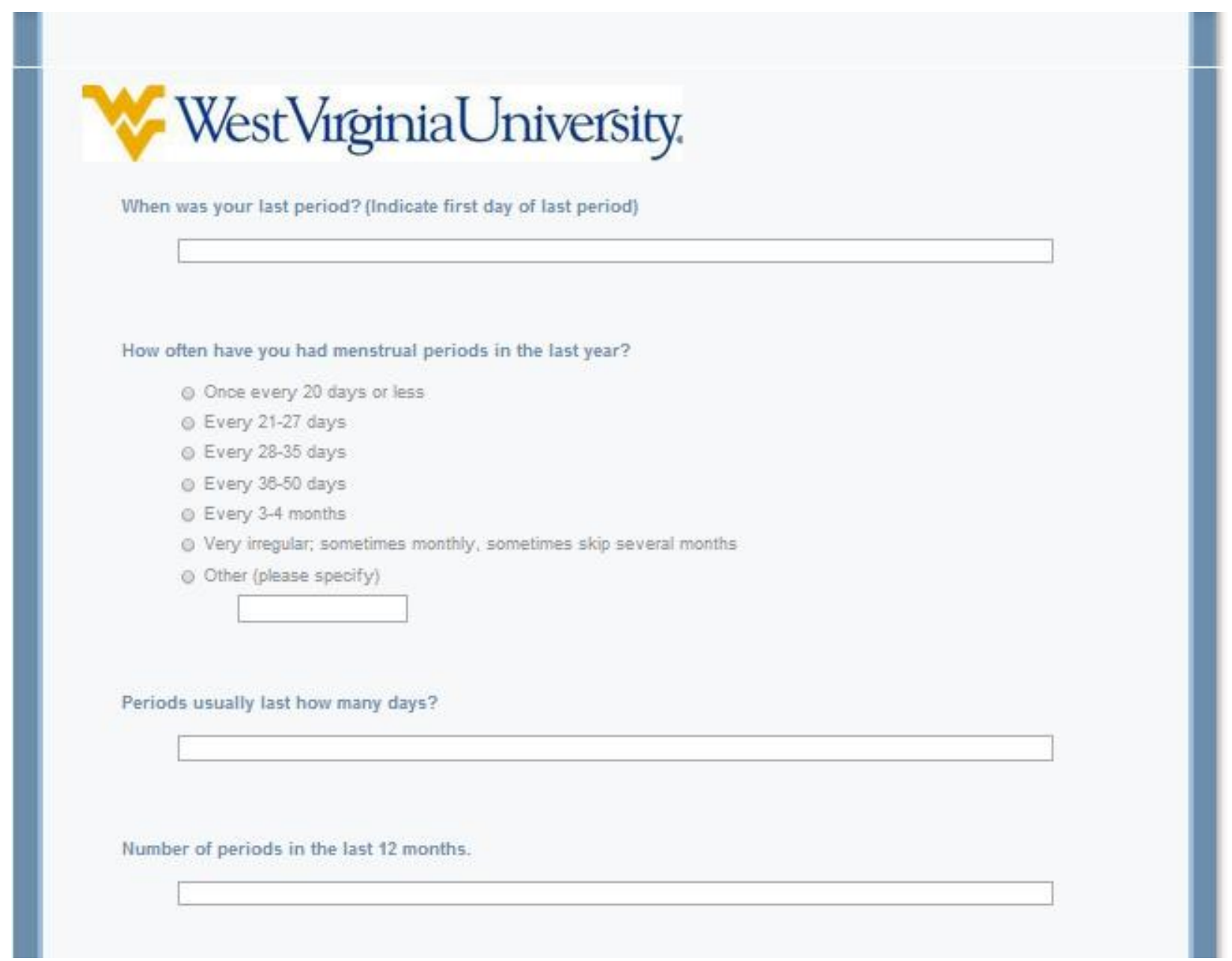


Do you keep track of your menstrual history?
$\circ \mathrm{Yes}$
○ No

Would you be willing to record your menstrual cycle?
○ Yes
No

Are you pregnant?

O Yes

○ No

Is there a possibility that you could be pregnant?
O Yes
№

Do you take any type of estrogens (i.e oral contraceptives)
- Yes (please explain)
№

Siees Surve; 


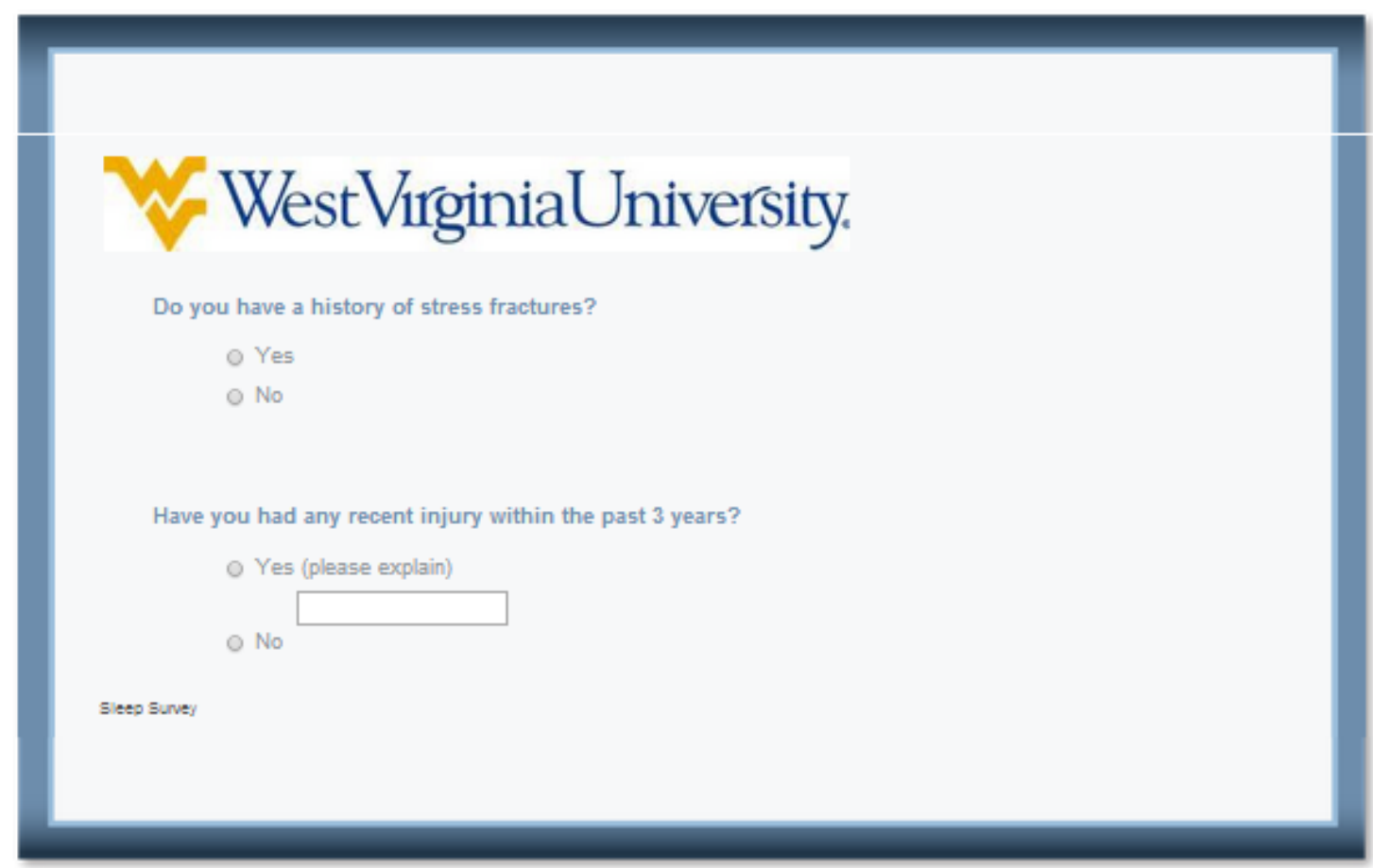




\section{APPENDIX E}

QUESTIONNAIRES/PROTOCOLS/ASSESSMENT TOOLS

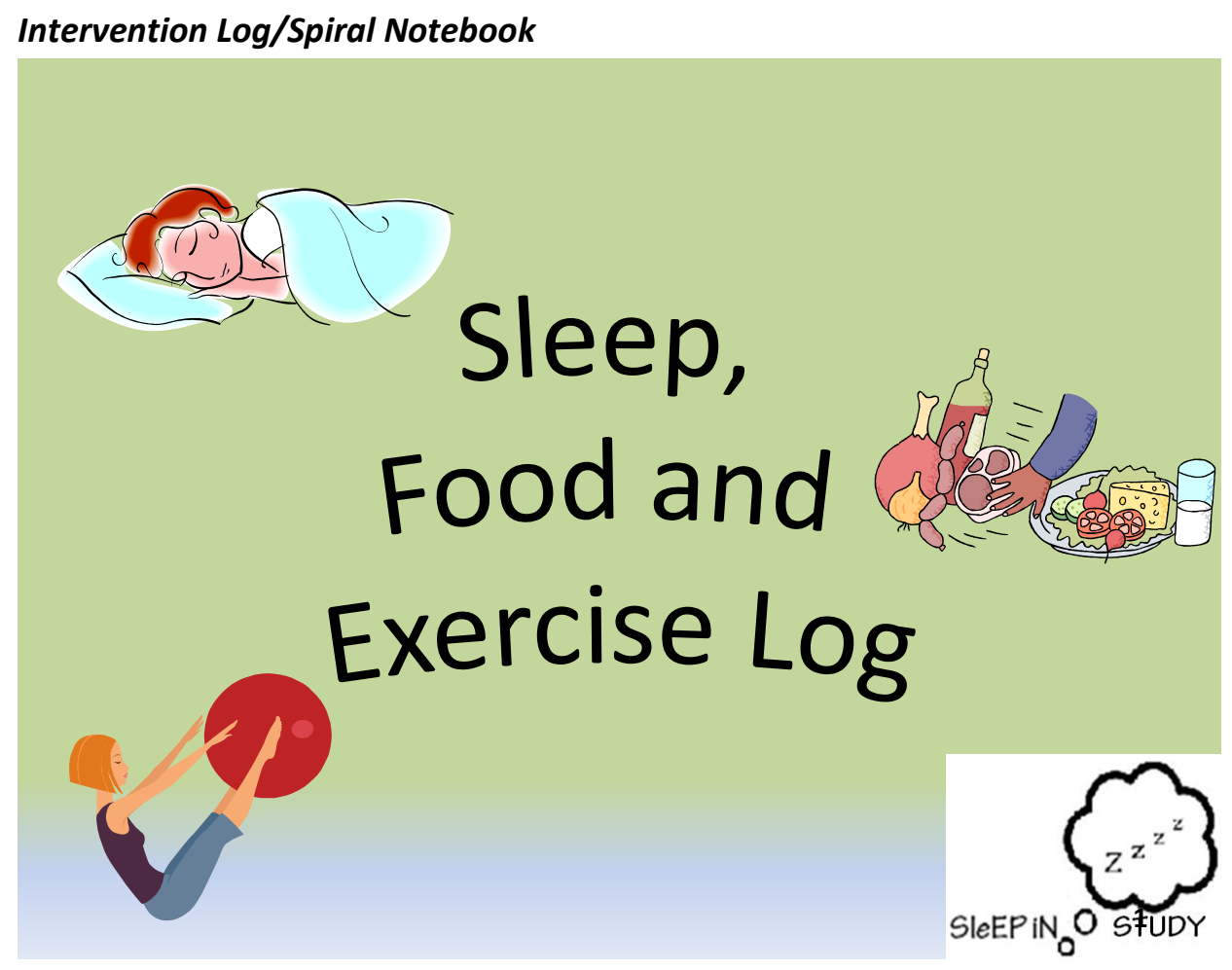




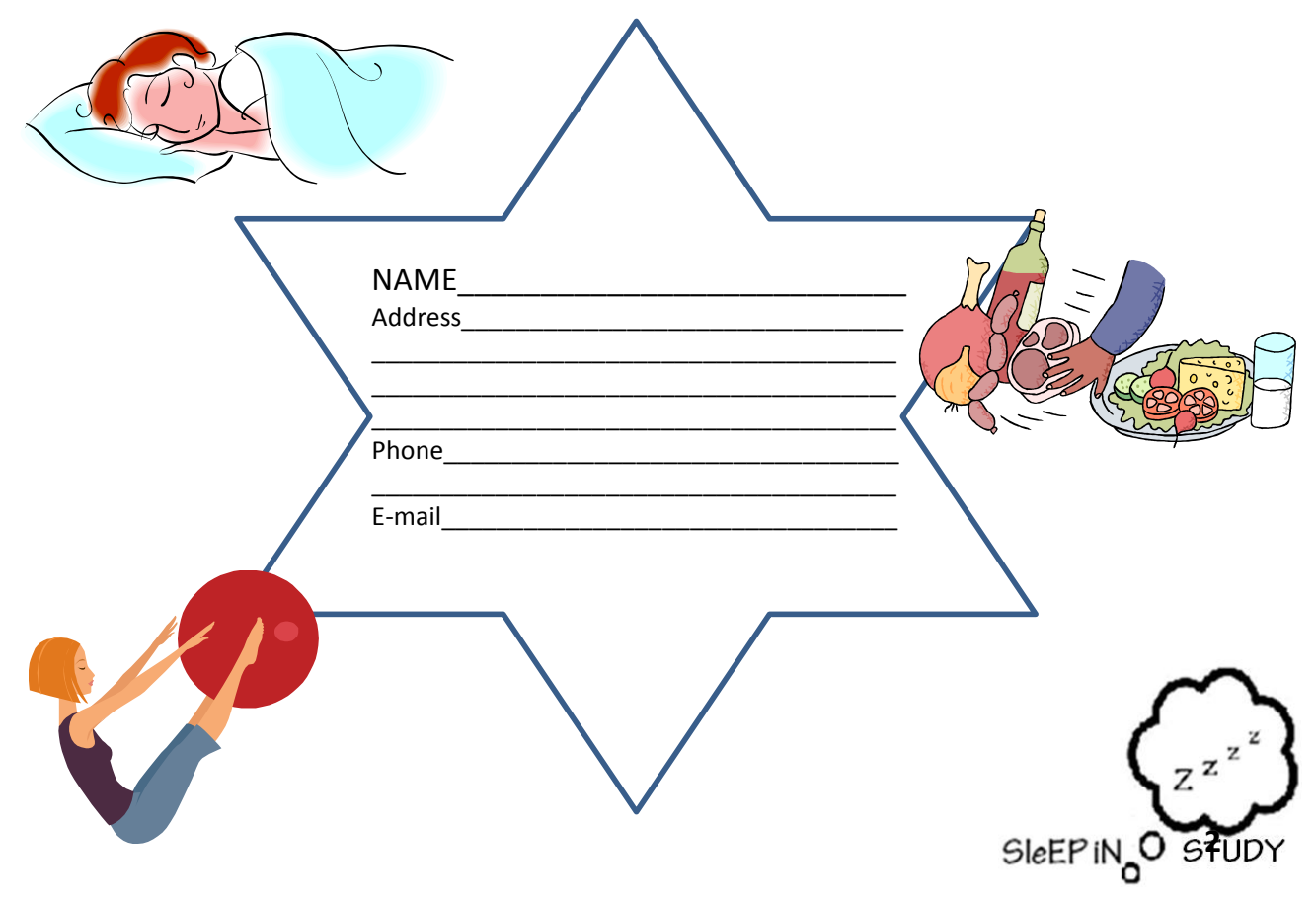

\section{SleEP iN Study}

Thank you for participating in the SleEP iN study!

Please use this notebook to track your sleep, exercise and nutrition for one week. Please be as specific as possible.

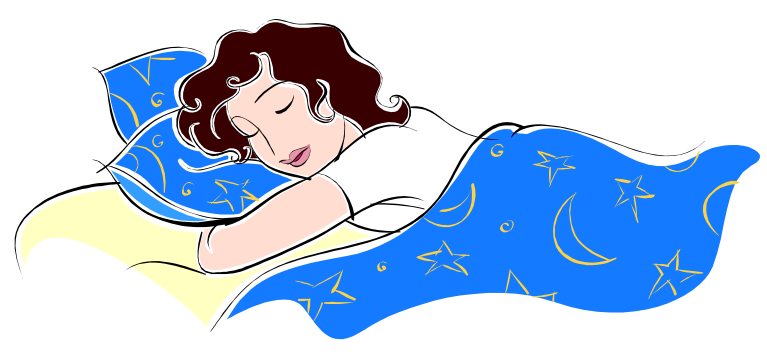

Oluremi Famodu

Research Coordinator oafamodu@mix.wvu.edu 612-281-1908

Ag. Sci Building Rm. \#1032 Melissa Olfert DrPH,MS,RD,LD

Principle Investigator melissa.olfert@mail.wvu.edu 304-293-1918 

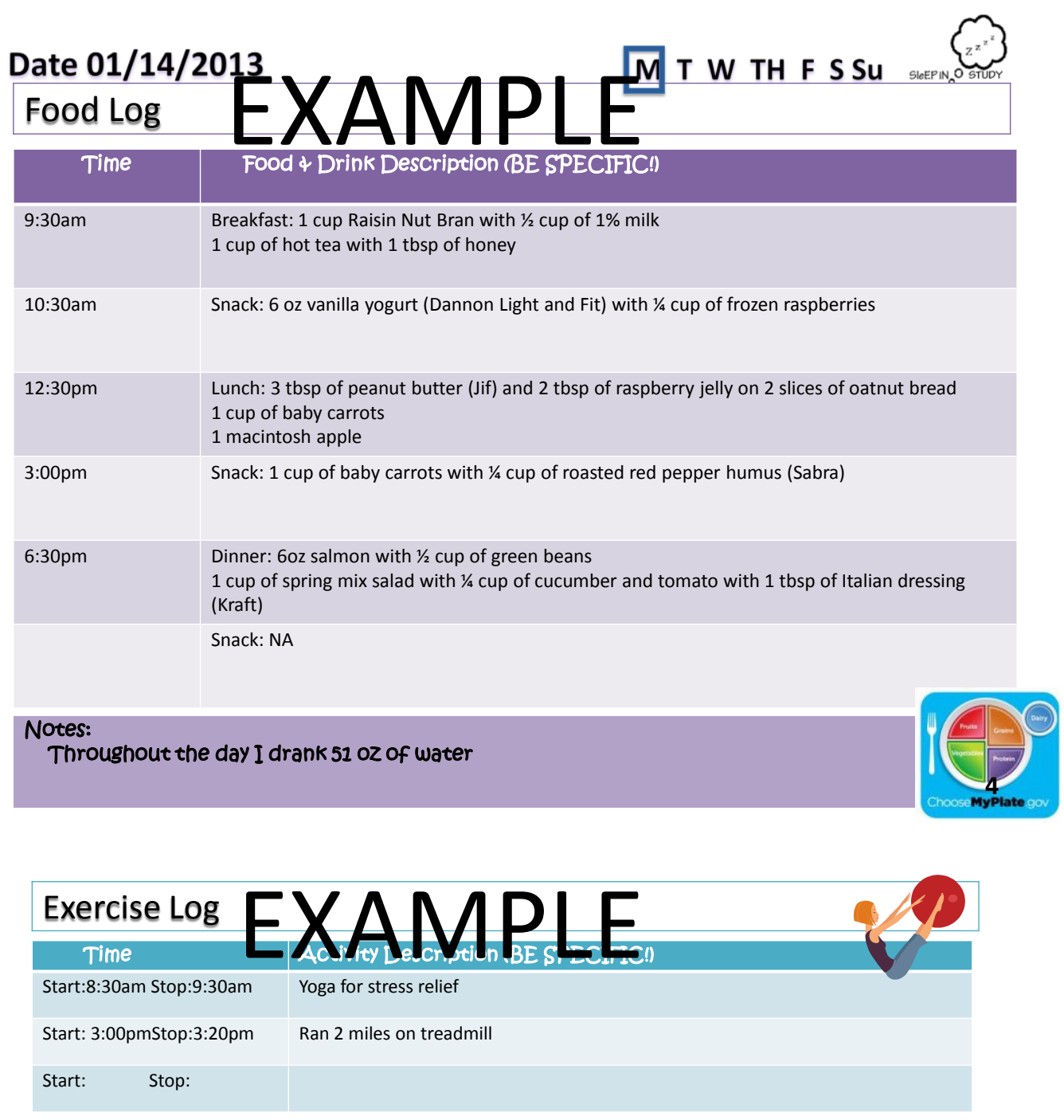

\section{Sleep Log}

\begin{tabular}{|c|c|c|c|}
\hline Time To Bed & \multicolumn{3}{|l|}{ 11:00 PM } \\
\hline Time Fell Asleep & \multicolumn{3}{|l|}{ 11:15PM } \\
\hline Time Woke Up & \multicolumn{3}{|l|}{ 8:00AM } \\
\hline Nap Times & 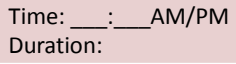 & $\begin{array}{l}\text { Time: } \\
\text { Duration: }\end{array}$ & $\begin{array}{l}\text { Time: } \_ \text {Duration: } \\
\text { AM/PM }\end{array}$ \\
\hline
\end{tabular}

Please use the sleepiness scale below to rate how you are feeling at the given times.

1: Feeling active, vital, alert and wide awake

2: Functioning at a high level, but not at peak; able to concentrate

3: Awake, but relaxed; responsive, but not fully alert

4: Somewhat foggy

5: Foggy; losing interest in remaining awake; slowed down

6: Sleepy, woozy, fighting sleep; prefer to lie down

7: No longer fighting sleep. Sleep onset soon; having dream like

thoughts

$\mathrm{X}$ : Asleep

\begin{tabular}{|r|l|}
\hline $9: 00 \mathrm{am}$ & 1 \\
\hline $11: 00 \mathrm{am}$ & 1 \\
\hline $1: 00 \mathrm{pm}$ & 1 \\
\hline $3: 00 \mathrm{pm}$ & 2 \\
\hline $5: 00 \mathrm{pm}$ & 3 \\
\hline $7: 00 \mathrm{pm}$ & 4 \\
\hline $9: 00 \mathrm{pm}$ & 5 \\
\hline $11: 00 \mathrm{pm}$ & 7 \\
\hline
\end{tabular}




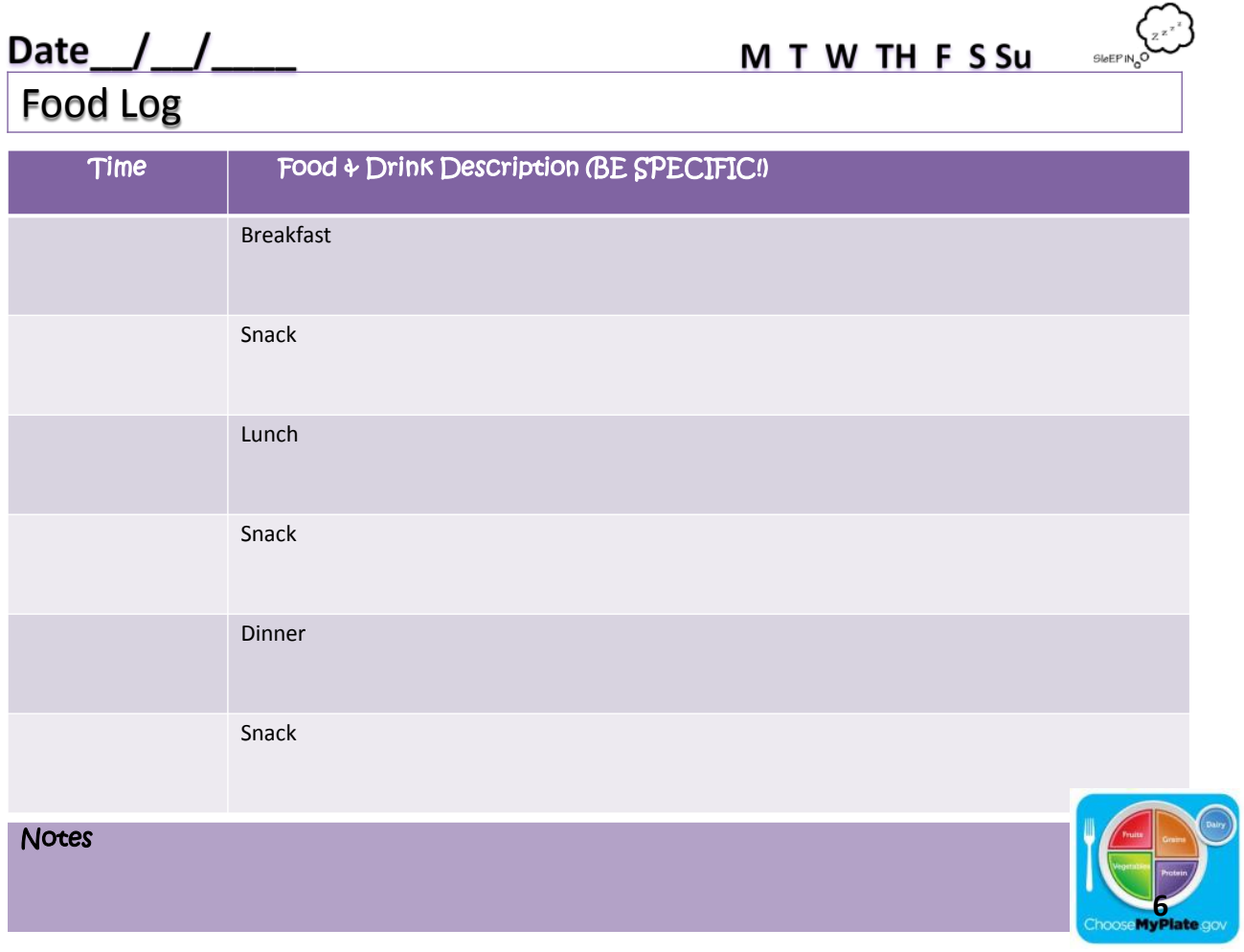

\section{Exercise Log}

\begin{tabular}{|c|c|c|}
\hline \multicolumn{2}{|c|}{ Time } & ACtivity Description (BE SPECIFIC!) \\
\hline Start: & Stop: & \\
\hline Start: & Stop: & \\
\hline Start: & Stop: & \\
\hline
\end{tabular}

\section{Sleep Log}

\begin{tabular}{|c|c|c|c|}
\hline Time To Bed & \multicolumn{3}{|l|}{$\ldots$ _ AM/PM } \\
\hline Time Fell Asleep & $\ldots$ _ & & \\
\hline Time Woke Up & $\ldots$ _ & & \\
\hline Nap Times & $\begin{array}{l}\text { Time: } \_ \text {Duration: } \\
\text { DM/PM }\end{array}$ & $\begin{array}{l}\text { Time: } \\
\text { Duration: }\end{array}$ & $\begin{array}{l}\text { Time: } \_ \text {Duration: } \\
\text { AM/PM }\end{array}$ \\
\hline
\end{tabular}

Please use the sleepiness scale below to rate how you are feeling at the given times.

1: Feeling active, vital, alert and wide awake

2: Functioning at a high level, but not at peak; able to concentrate

3: Awake, but relaxed; responsive, but not fully alert

4: Somewhat foggy

5: Foggy; losing interest in remaining awake; slowed down

6: Sleepy, woozy, fighting sleep; prefer to lie down

7: No longer fighting sleep. Sleep onset soon; having dream like

thoughts

$\mathrm{X}$ : Asleep

\begin{tabular}{|r|r|}
\hline $9: 00 \mathrm{am}$ & \\
\hline $11: 00 \mathrm{am}$ & \\
\hline $1: 00 \mathrm{pm}$ & \\
\hline $3: 00 \mathrm{pm}$ & \\
\hline $5: 00 \mathrm{pm}$ & \\
\hline $7: 00 \mathrm{pm}$ & \\
\hline $9: 00 \mathrm{pm}$ & \\
\hline $11: 00 \mathrm{pm}$ & \\
\hline
\end{tabular}




\begin{tabular}{|c|c|}
\hline \multicolumn{2}{|l|}{$\begin{array}{l}\text { This is a quick way to assess how alert you are feeling. If it is during } \\
\text { about your business, ideally you would want a rating of a one. Take } \\
\text { people have two peak times of alertness daily, at about } 9 \text { a.m. and } 9 \text { p } \\
\text { its lowest point at around } 3 \text { p.m.; after that it begins to build again. } \\
\text { different times during the day. If you go below a three when you shou } \\
\text { is an indication that you have a serious sleep debt and you ne } \\
\text { An Introspective Measure of Sleepiness } \\
\text { The Stanford Sleepiness Scale (SSS) }\end{array}$} \\
\hline Degree of Sleepiness & $\begin{array}{l}\text { Scale } \\
\text { Rating }\end{array}$ \\
\hline Feeling active, vital, alert, or wide awake & 1 \\
\hline $\begin{array}{l}\text { Functioning at high levels, but not at peak; able to } \\
\text { concentrate }\end{array}$ & 2 \\
\hline Awake, but relaxed; responsive but not fully alert & 3 \\
\hline Somewhat foggy, let down & 4 \\
\hline $\begin{array}{l}\text { Foggy; losing interest in remaining awake; slowed } \\
\text { down }\end{array}$ & 5 \\
\hline Sleepy, woozy, fighting sleep; prefer to lie down & 6 \\
\hline $\begin{array}{l}\text { No longer fighting sleep, sleep onset soon; having } \\
\text { dream-like thoughts }\end{array}$ & 7 \\
\hline Asleep & $\mathrm{X}$ \\
\hline
\end{tabular}




\title{
Centers for Disease Control and Prevention Health-Related Quality-of- Life 14-Item Measure
}

\author{
CDC HRQOL-14 \\ "Healthy Days Measure"
}

\begin{abstract}
Healthy Days Core Module (4 questions)
Activity Limitations Module (5 questions)

Healthy Days Symptoms Module (5 questions)
\end{abstract}

Division of Adult and Community Health

National Center for Chronic Disease Prevention and Health Promotion

The standard 4-item set of Healthy Days core questions (CDC HRQOL-4) has been in the State-based Behavioral Risk Factor Surveillance System (BRFSS) since 1993 (see BRFSS Website http://www.cdc.gov/brfss). Since 2000, the CDC HRQOL-4 has been in the National Health and Nutrition Examination Survey (NHANES) for persons aged 12 and older. Since 2003, the CDC HRQOL-4 has been in the Medicare Health Outcome Survey (HOS) - a NCQA HEDIS measure. Standard Activity Limitation and Healthy Days Symptoms modules have also been available since January 1995. When used together, these measures comprise the full CDC HRQOL-14 Measure.

\section{Healthy Days Core Module (CDC HRQOL-4)}

1. Would you say that in general your health is:

Please Read
a. Excellent
1
b. Very good
2
c. Good
3
d. Fair
4

or

e. Poor 5

Do not read these responses

Don't know/Not sure 7

Refused 9

2. Now thinking about your physical health, which includes physical illness and injury, for how many days during the past 30 days was your physical health not good?

a. Number of Days

b. None $\overline{8} \overline{8}$

Don't know/Not sure 77

Refused 
3. Now thinking about your mental health, which includes stress, depression, and problems with emotions, for how many days during the past 30 days was your mental health not good?

a. Number of Days

b. None

$$
88
$$

If both Q2 AND Q3 ="None", skip next

Don't know/Not sure question

Refused

99

4. During the past 30 days, for about how many days did poor physical or mental health keep you from doing your usual activities, such as self-care, work, or recreation?

a. Number of Days

b. None

$\overline{8} \overline{8}$

Don't know/Not sure 77

Refused

99

Back to top

\section{Activity Limitations Module}

These next questions are about physical, mental, or emotional problems or limitations you may have in your daily life.

1. Are you LIMITED in any way in any activities because of any impairment or health problem?
a. Yes
1
b. No
2 Go to Q1 of Healthy Days
Don't know/Not sure 7 Go to Q1 of Healthy Days Symptoms Module
Refused
$9 \begin{aligned} & \text { Go to Q1 of Healthy Days } \\ & \text { Symptoms Module }\end{aligned}$

2. What is the MAJOR impairment or health problem that limits your activities?

Do Not Read. Code Only One Category.
a. Arthritis/rheumatism
01
b. Back or neck problem
02
c. Fractures, bone/joint injury
03
d. Walking problem
04
e. Lung/breathing problem
05
f. Hearing problem
06
g. Eye/vision problem
07
h. Heart problem
08
i. Stroke problem
09
j. Hypertension/high blood pressure 10
k. Diabetes
11 
I. Cancer

$\mathrm{m}$. Depression/anxiety/emotional problem 13

n. Other impairment/problem $\quad 14$

Don't know/Not sure 77

Refused 99

3. For HOW LONG have your activities been limited because of your major impairment or health problem?

Do Not Read. Code using respondent's unit of time.
a. Days
1
b. Weeks
2
c. Months
3
d. Years

Don't know/Not sure 777

Refused $\quad 999$

4. Because of any impairment or health problem, do you need the help of other persons with your PERSONAL CARE needs, such as eating, bathing, dressing, or getting around the house?
a. Yes
1
b. No
2
Don't know/Not sure Refused
7

5. Because of any impairment or health problem, do you need the help of other persons in handling your ROUTINE needs, such as everyday household chores, doing necessary business, shopping, or getting around for other purposes?
a. Yes
1
b. No
Don't know/Not sure
Refused
7
9

\section{Back to top}

\section{Healthy Days Symptoms Module}

1. During the past 30 days, for about how many days did PAIN make it hard for you to do your usual activities, such as self-care, work, or recreation?
a. Number of Days
b. None $\overline{8} \overline{8}$
Don't know/Not sure 77
Refused
99

2. During the past 30 days, for about how many days have you felt SAD, BLUE, or DEPRESSED? 

a. Number of Days
b. None
$\overline{8} \overline{8}$
Don't know/Not sure 77
Refused 99

3. During the past 30 days, for about how many days have you felt WORRIED, TENSE, or ANXIOUS?

a. Number of Days

b. None

$\overline{8} \overline{8}$

Don't know/Not sure 77

Refused $\quad 99$

4. During the past 30 days, for about how many days have you felt you did NOT get ENOUGH REST or SLEEP?

a. Number of Days

b. None

$\overline{8} \overline{8}$

Don't know/Not sure 77

Refused

99

5. During the past 30 days, for about how many days have you felt VERY HEALTHY AND FULL OF ENERGY?

a. Number of Days

b. None

$\overline{8} \overline{8}$

Don't know/Not sure 77

Refused

99 


\section{Perceived Stress Scale}

The questions in this scale ask you about your feelings and thoughts during the last month. In each case, you will be asked to indicate by circling how often you felt or thought a certain way.

Name

Date

Age Gender (Circle): M F Other

$$
0=\text { Never } \quad \mathbf{1}=\text { Almost Never } \quad 2 \text { = Sometimes } \quad 3=\text { Fairly Often } \quad 4=\text { Very Often }
$$

1. In the last month, how often have you been upset because of something that happened unexpectedly? $\begin{array}{llll}0 & 1 & 2 & 3\end{array}$

2. In the last month, how often have you felt that you were unable to control the important things in your life? $\begin{array}{lllll}0 & 1 & 2 & 3 & 4\end{array}$

3. In the last month, how often have you felt nervous and "stressed"? $\begin{array}{llll}0 & 1 & 2 & 3\end{array}$

4. In the last month, how often have you felt confident about your ability to handle your personal problems? $\begin{array}{lllll}0 & 1 & 2 & 3 & 4\end{array}$

5. In the last month, how often have you felt that things were going your way? $\begin{array}{llll}0 & 1 & 2 & 3\end{array}$

6. In the last month, how often have you found that you could not cope with all the things that you had to do?

7. In the last month, how often have you been able to control irritations in your life?

$\begin{array}{llllllll}\text { 8. In the last month, how often have you felt that you were on top of things?.. } & 0 & 1 & 2 & 3 & 4\end{array}$

9. In the last month, how often have you been angered because of things that were outside of your control?

10. In the last month, how often have you felt difficulties were piling up so high that you could not overcome them?

Please feel free to use the Perceived Stress Scale for your research.

\section{Mind Garden, Inc. info@mindgarden.com www.mindgarden.com}

\section{References}

The PSS Scale is reprinted with permission of the American Sociological Association, from Cohen, S., Kamarck, T., and Mermelstein, R. (1883). A global measure of perceived stress. Joumal of Health and Social Behavior, 24, 396-396.

Cohen, S. and Williamson, G. Perceived Stress in a Probability Sample of the United States. Spacapan, S. and Oskamp, S. (Eds.) The Social Psychology of Health. Newbury Park, CA: Sage, 1888. 
PROFILE OF MOOD STATES

Directions: Describe HOW YOU FEEL RIGHT NOW by checking one space after each of the words listed below:

FEELING

Friendly

Tense

Angry

Worn Out

Unhappy

Clear-headed

Lively

Confused

Sony for things done

Shaky

Listless

Peeved

Considerate

Sad

Active

On edge

Grouchy

Blue

Energetic

Panicky

Hopeless

Relaxed

Unworthy

Spiteful

Sympathetic

Uneasy

Restless

Unable to concentrate

Fatigued

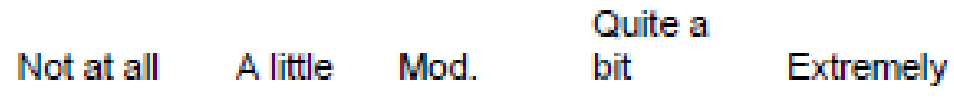

1

1

1

1

1

1

1

1

1

1

1

1

1

1

1

1

1

1

1

1

1

1

1

1

1

1

1

1

1

12

12

12

12

1

2

2

2

2

2

2

2

2

2

2

2

2

2

2

2

2

2

2

2

2

2

2

2

2

2

2

2

2

2

2

3

3

45

3

3

3

3

3

3

3

3

3

3

3

3

3

3

3

3
3

3

3

3
3

3

3

3

3

3

3

3

3
3

3

$\begin{array}{ll}4 & 5 \\ 4 & 5 \\ 4 & 5\end{array}$

$\begin{array}{ll}4 & 5 \\ 4 & 5\end{array}$

$\begin{array}{ll}4 & 5 \\ 4 & 5\end{array}$

$\begin{array}{ll}4 & 5 \\ 4 & 5\end{array}$

$\begin{array}{ll}4 & 5 \\ 4 & 5 \\ 4 & 5\end{array}$

$\begin{array}{ll}4 & 5 \\ 4 & 5\end{array}$

$\begin{array}{ll}4 & 5 \\ 4 & 5\end{array}$

$\begin{array}{ll}4 & 5 \\ 4 & 5\end{array}$

$\begin{array}{ll}4 & 5 \\ 4 & 5 \\ 4 & 5\end{array}$

$\begin{array}{ll}4 & 5 \\ 4 & 5\end{array}$

$\begin{array}{ll}4 & 5 \\ 4 & 5 \\ 4 & 5\end{array}$

$\begin{array}{ll}4 & 5 \\ 4 & 5\end{array}$

$\begin{array}{ll}4 & 5 \\ 4 & 5\end{array}$

$\begin{array}{ll}4 & 5 \\ 4 & 5 \\ 4 & 5\end{array}$

$\begin{array}{ll}4 & 5 \\ 4 & 5\end{array}$

$\begin{array}{ll}4 & 5 \\ 4 & 5 \\ 4 & 5\end{array}$

\begin{tabular}{ll}
4 & 5 \\
4 & 5 \\
4 & 5 \\
4 & 5 \\
\hline
\end{tabular}




\begin{tabular}{|c|c|c|c|c|c|}
\hline Helpfil & 1 & 2 & 3 & 4 & 5 \\
\hline Annoyed & 1 & 2 & 3 & 4 & 5 \\
\hline Discouraged & 1 & 2 & 3 & 4 & 5 \\
\hline Resentfiul & 1 & 2 & 3 & 4 & 5 \\
\hline Nervous & 1 & 2 & 3 & 4 & 5 \\
\hline Lonely & 1 & 2 & 3 & 4 & 5 \\
\hline Misenable & 1 & 2 & 3 & 4 & 5 \\
\hline Mudiled & 1 & 2 & 3 & 4 & 5 \\
\hline Cherfin & 1 & 2 & 3 & 4 & 5 \\
\hline Bitter & 1 & 2 & 3 & 4 & 5 \\
\hline Exharisted & 1 & 2 & 3 & 4 & 5 \\
\hline Anvious & 1 & 2 & 3 & 4 & 5 \\
\hline Ready to fight & 1 & 2 & 3 & 4 & 5 \\
\hline Good-natured & 1 & 2 & 3 & 4 & 5 \\
\hline Glooury & 1 & 2 & 3 & 4 & 5 \\
\hline Despente & 1 & 2 & 3 & 4 & 5 \\
\hline Shugish & 1 & 2 & 3 & 4 & 5 \\
\hline Rebellivus & 1 & 2 & 3 & 4 & 5 \\
\hline Helpless & 1 & 2 & 3 & 4 & 5 \\
\hline Weary & 1 & 2 & 3 & 4 & 5 \\
\hline Benildered & 1 & 2 & 3 & 4 & 5 \\
\hline Alert & 1 & 2 & 3 & 4 & 5 \\
\hline Deceived & 1 & 2 & 3 & 4 & 5 \\
\hline Furious & 1 & 2 & 3 & 4 & 5 \\
\hline Eficious: & 1 & 2 & 3 & 4 & 5 \\
\hline Trusting & 1 & 2 & 3 & 4 & 5 \\
\hline Full of pep & 1 & 2 & 3 & 4 & 5 \\
\hline Bud-tempered & 1 & 2 & 3 & 4 & 5 \\
\hline Worthless & 1 & 2 & 3 & 4 & 5 \\
\hline Forgetfil & 1 & 2 & 3 & 4 & 5 \\
\hline Carefiee & 1 & 2 & 3 & 4 & 5 \\
\hline Terrified & 1 & 2 & 3 & 4 & 5 \\
\hline Guily & 1 & 2 & 3 & 4 & 5 \\
\hline Vigorous & 1 & 2 & 3 & 4 & 5 \\
\hline Dhestuhi ilsul thing & 1 & 2 & 3 & 4 & 5 \\
\hline Bubled & 1 & 2 & 3 & 4 & 5 \\
\hline
\end{tabular}


APPENDIX F

DATE COLLECTION FORM

Demographics/Contact Information

\begin{tabular}{|l|l|}
\hline Name: Last, First & Sport: \\
\hline ID \#: & $\begin{array}{l}\text { Year in School (circle) Freshman } \\
\text { Sophomore Junior Senior } \\
\text { Graduate }\end{array}$ \\
\hline Age: & $\begin{array}{l}\text { Sirthdate (mo/day/yr) } \\
\text { Campus ADDRESS: }\end{array}$ \\
\hline CELL PHONE \# (with area code): & EMAIL ADDRESS: \\
\hline email $\square$ day phone $\square$ cell phone $\square$ Other, specify: & \\
\hline BEST WAY TO CONTACT (check any applicable box):
\end{tabular}

Physical Assessment

\begin{tabular}{|l|l|l|}
\hline Subject ID \# & \multicolumn{1}{|c|}{ Baseline } & \\
\hline Actigraph \#: & & \\
\hline DATE & & \\
\hline TIME & & \\
\hline $\begin{array}{l}\text { RESEARCHER who } \\
\text { completed } \\
\text { assessment }\end{array}$ & & \\
\hline
\end{tabular}




\begin{tabular}{|c|c|c|c|c|c|c|}
\hline & Measure 1 & Measure 2 & $\begin{array}{c}\text { Average of } \\
1 \& 2^{* *}\end{array}$ & Measure 1 & Measure 2 & $\begin{array}{c}\text { Average of } \\
1 \& 2^{* *}\end{array}$ \\
\hline WEIGHT (kg) & & & $*$ & & & $*$ \\
\hline HEIGHT (cm) & & & $*$ & & & $*$ \\
\hline $\begin{array}{l}\text { WAIST } \\
\text { CIRCUMFERENCE } \\
(\mathrm{cm})\end{array}$ & & & $*$ & & & $*$ \\
\hline $\begin{array}{l}\text { BLOOD PRESSURE } \\
(\mathrm{mm} / \mathrm{Hg})\end{array}$ & & & $*$ & & & $*$ \\
\hline BMI Calculation & & & & & & \\
\hline \% Body Fat (BodPod) & & & & & & \\
\hline $\begin{array}{l}\text { Psychomotor } \\
\text { Vigilance Test (PVT) }\end{array}$ & $\begin{array}{l}\text { Test Duration: } \\
\text { False Starts: }\end{array}$ & \multicolumn{2}{|c|}{$\begin{array}{l}\text { Signals Missed: } \\
\text { Avg. Rxtn Time: }\end{array}$} & \multicolumn{3}{|c|}{$\begin{array}{ll}\text { Test Duration: } & \text { Signals Missed: } \\
\text { False Starts: } & \text { Avg. Rxtn Time: }\end{array}$} \\
\hline $\begin{array}{l}\text { Wingate Protocol } \\
\text { Assessment } \\
\text { (resistance, distance) }\end{array}$ & & & & & & \\
\hline $\begin{array}{l}\text { Power Output } \\
\text { (Watts) } \\
\text { Fatigue Index } \\
\text { (Watts } / \mathrm{sec} \text { ) }\end{array}$ & & & & & & \\
\hline $\begin{array}{l}\text { CONCERNS FOR } \\
\text { ERROR (for weight, } \\
\text { height, waist } \\
\text { circumference } \\
\text { measures, blood } \\
\text { pressure) }\end{array}$ & & & & & & \\
\hline
\end{tabular}

* Enter these data on excel file for each participant

** Round the average of the two official measurements to two decimal places (e.g. 0.2 $+0.3=0.5 / 2=0.25)$. 


\section{CURRICULUM VITAE of Oluremi Famodu}

I was born in Bloomington, MN. I graduated from John F. Kennedy High School in 2008 and began my undergraduate course work at Ohio University (OU) in Athens, $\mathrm{OH}$ in the fall of 2008. Being a member of the Varsity Women's Soccer Team for four years and having received the Ohio Collegiate Soccer Association Academic Recognition Second Team along with Ohio Academic AllMAC Honorable Mention in 2012, I bring a deep understanding to the dedication of an athlete. I became a member and publicity chair of the national honor society, Phi Upsilon Omicron, and also participated in the Health Sciences and Professions honors program in 2011. At OU I received a Bachelor of Science degree in Applied Nutrition and received the Outstanding Graduate in the college of Applied Health Sciences and Wellness in June 2012.

In August 2012, I was accepted into the Master's program in the Division of Animal and Veterinary Sciences at WVU, as well as receiving a part-time graduate assistantship, which continued until May 2013. This research work is in part fulfillment of earning a Master's degree projected for May 2014, followed by sitting for the national Registered Dietetics (RD) exam shortly thereafter. 